\title{
SITUAÇÕES TRIANGULARES EM GÊMEOS DURANTE O PRIMEIRO ANO DE VIDA: CONJECTURAS SOBRE O COMPLEXO DE ÉDIPO
}


MARIA ELIZABETH BARRETO DE PINHO TAVARES

\section{SITUAÇÕES TRIANGULARES EM GÊMEOS DURANTE O PRIMEIRO ANO DE VIDA: CONJECTURAS SOBRE O COMPLEXO DE ÉDIPO}

Tese apresentada ao Instituto de Psicologia da Universidade de São Paulo, como requisito

parcial à obtenção do título de Doutora.

Área de Concentração: Psicologia Clínica

Orientador: Prof. Dr. Ryad Simon

São Paulo

2007 
AUTORIZO A REPRODUÇÃO E DIVULGAÇÃO TOTAL OU PARCIAL DESTE TRABALHO, POR QUALQUER MEIO CONVENCIONAL OU ELETRÔNICO, PARA FINS DE ESTUDO E PESQUISA, DESDE QUE CITADA A FONTE.

Catalogação na Publicação Elaborada pela Divisão de Processos Técnicos da Biblioteca Central da Universidade Estadual de Londrina

\section{Dados Internacionais de Catalogação-na-Publicação (CIP)}

T231s Tavares, Maria Elizabeth Barreto de Pinho.

Situações triangulares em gêmeos durante o primeiro ano de vida : conjecturas sobre o complexo de édipo / Maria Elizabeth Barreto de Pinho Tavares. - São Paulo, 2007.

$178 f$.

Orientador: Ryad Simon.

Tese(Doutorado em Psicologia Clínica) - Universidade de São Paulo. Instituto de Psicologia, 2007.

Inclui bibliografia.

1. Psicologia clínica - Teses. 2. Édipo, Complexo - Psicologia Teses. 3. Relações objetais (Psicanálise) - Teses. 4. Gêmeos Psicologia - Teses. I. Simon, Ryad. II. Universidade de São Paulo. Instituto de Psicologia. III. Titulo. 


\section{FOLHA DE APROVAÇÃO}

Maria Elizabeth Barreto de Pinho Tavares

Situações triangulares em gêmeos durante o primeiro ano de vida: conjecturas sobre o Complexo de Édipo

Tese apresentada ao Instituto de Psicologia da Universidade de São Paulo, como requisito

parcial à obtenção do título de Doutora.

Aprovado em:

Banca Examinadora

Prof.Dr.

Instituição:

Assinatura:

Prof.Dr.

Instituição:

Assinatura:

Prof.Dr.

Instituição:

Assinatura:

Prof.Dr.

Instituição:

Assinatura:

Prof.Dr

Instituição:

Assinatura: 
Aos gêmeos,

que tanto me encantam! 


\section{AGRADECIMENTOS}

Ao prof. Dr. Ryad Simon, que tão bem me acolheu e ajudou a desenvolver as idéias sobre as relações afetivas em gêmeos.

Às famílias dos gêmeos que possibilitaram a realização deste estudo.

Às psicanalistas Marisa Pellela Mélega e Daise Bracco, que me ensinaram a observar os bebês.

Ao meu filho, Alexandre, que precisou dividir o colo materno com a chegada das irmãs gêmeas.

Às minhas filhas, Marina e Letícia, cujo nascimento motivou as pesquisas sobre a gemelaridade.

À minha mãe, Edna, que sempre apoiou a realização do sonho do doutorado.

Ao meu marido, Nelio, cujo amor e ternura tanto me ajudaram na conclusão deste trabalho. 
E Deus parece existir Gêmeo da própria beleza! Marialzira Perestrello 


\section{RESUMO}

TAVARES, Maria Elizabeth Barreto de Pinho. Situações triangulares em gêmeos durante o primeiro ano de vida: conjecturas sobre o Complexo de Édipo. 2007. Tese (Doutorado em Psicologia Clínica) - Universidade de São Paulo.

Na literatura psicológica, encontramos pesquisas realizadas com gêmeos visando estudar a influência de fatores genéticos versus ambientais na estruturação da personalidade e também no campo da psicopatologia. Entretanto, existem poucos relatos de pesquisas voltados para a interação intra-par de gêmeos e entre os gêmeos e seus cuidadores, especialmente em relação às questões edípicas. $O$ fenômeno, tão estudado pela psicanálise, tem sido pouco investigado na vivência de situações triangulares entre os co-gêmeos e seus pais. O método de Observação Psicanalítica modelo Esther Bick inspirou o planejamento desta tese, que tem como objetivos: observar e descrever as relações objetais triangulares entre os gêmeos e seus pais durante o primeiro ano de vida; analisar a possibilidade de a triangulação edípica ocorrer prioritariamente entre o par de gêmeos; verificar se a "presença real" do co-gêmeo poderia exacerbar a vivência como "terceiro excluído" entre os gêmeos. Participaram cinco pares de gêmeos recém-nascidos e suas respectivas famílias, sendo dois pares masculinos(monozigoto e dizigoto), dois pares femininos (monozigoto e dizigoto) e um par de sexos diferentes. Foram realizadas visitas semanais com duração de uma hora cada, às residências dos gêmeos, durante o primeiro ano de vida, a fim de observar os gêmeos e seus cuidadores. A observadora pode presenciar o que se passava na relação intra-par de gêmeos, bem como entre os gêmeos e demais pessoas presentes. Após cada sessão de observação foi elaborado um relatório constando os comportamentos observados e as percepções da observadora em relação aos fatos. Foram estudados especialmente os seguintes fenômenos observados nas famílias de gêmeos: atendimento individual mãe-gêmeos; atendimento conjunto mãe-gêmeos; disputa de colo/atenção materna; atendimento pai-gêmeos; relacionamento intra-par de gêmeos. As relações triangulares envolvendo os co-gêmeos e seus pais foram analisadas, tendo como subsídio as teorias de Freud e Klein a respeito das questões edípicas. Foram percebidas quatro formas de relação triangular além do triângulo edípico filho-mãe-pai nas famílias estudadas.

Palavras-chave: complexo de Édipo, gêmeos, relações objetais. 


\begin{abstract}
TAVARES, Maria Elizabeth Barreto de Pinho. Triangular situations in twins during the first year of life: conjectures about the Oedipus Complex. 2007. Thesis (Doctorate in Clinical Psycology) University of São Paulo.

In the psychological literature, we have found researches performed with twins where the aim was to study the influence of genetic factors versus environmental ones in the structuring of the personality and also in the field of the psychology. However, there are few reports of researches related to the twins' intra-pair interaction and between the twins and their caretakers, especially in relation to the oedipal issues. The phenomenon, so studied by the psychoanalysis, has been little investigated in the experience of triangular situations between the co-twins and their parents. Esther Bick method of Psychoanalytic Observation model inspired the planning of this thesis, which has as its objectives: to observe and to describe the oppose triangular relationships between the twins and their parents during the first year of life; to analyze the possibility that the oedipal triangulation may happen essentially between the pair of twins; to verify if the "real presence" of the co-twin could exacerbate the existence as a "third excluded" between the twins. Five pairs of just born twins and their respective families participated in the study; among them we have two male pairs (monozygotic and dizygotic twins), two female pairs (monozygotic and dizygotic twins) and a pair of different sexes. Weekly visits were carried out with an hour duration each, to the twins' residences, during the first year of life, in order to observe the twins and their caretakers. The observer could witness what happened in the twins' intra-pair relationship, as well as between the twins and among the other people present. After each observation session a report was elaborated including the observed behaviors and the observer's perceptions related to the facts. The following observed phenomena were specially studied in the twins' families: individual attendance mother-twin; pair attendance mother-twins; dispute of mother's holding/attention; father-twins attendance; twins' intra-pair relationship. The triangular relationships involving the co-twins and their parents were analyzed, having as its subsidy Freud's and Klein's theories regarding to oedipal relations. It has been noticed four triangular relationship forms besides the triangle son-mother-father oedipal one in the studied families.
\end{abstract}

Words key: Oedipus complex, twins, oppose triangular relationships 


\section{RÉSUMÉ}

TAVARES, Maria Elizabeth Barreto de Pinho. Situations triangulaires chez les jumeaux durant la première année de vie: conjectures sur le Complexe d'Oedipe. 2007. Thèse (Doctorat en Psychologie Clinique) - Université de São Paulo.

La littérature en psychologie, nous offre des recherche réalisées sur des jumeaux et ayant pour but d'étudier l'influence des facteurs génétiques versus milieux ambiants dans la structure de la personnalité tout comme dans le domaine de la psychopathologie. Toutefois, il existe peu de rapports écrits à propos de recherches ciblant d'une part l'interaction intra-paire de jumeaux et d'autre part celle des jumeaux et des personnes qui s'en occupent, notamment autour de la question des relations oedipiennes. Le phénomène, tant étudié par la psychanalyse,a pourtant moins fait l'objet d'enquête en ce qui concerne l'expérience vécue dans des situations triangulaires entre les co-jumeaux et leurs parents. La méthode d'Observation Psychanalytique modèle Esther Bick a inspiré le projet d'étude de cette thèse. Ce dernier a pour objectifs: d'observer et de décrire les relations objectales triangulaires entre les parents et leurs jumeaux durant leur première année de vie ; d'analyser que la possibilité de la triangulation oedipienne pourrait se développer prioritairement entre la paire de jumeaux; de vérifier si la "présence réelle" du co-jumeau pourrait exacerber l'expérience de vie comme "troisième exclu" entre les jumeaux. Cinq paires de jumeaux nouveaux-nés et leurs respectives familles y ont participé, dont deux paires masculines(monozygote et dizygote), deux paires féminines (monozygote et dizygote), et une paire de sexes différents. Durant leur première année de vie, des visites hebdomadaires, d'une durée d'une heure chacune, ont été effectuées dans les résidences des jumeaux, afin d'observer les jumeaux et les personnes en prenant soin . L'observatrice a pu témoigner de ce qui se passait dans la relation intra-paire de jumeaux, tout comme entre les jumeaux et d'autres personnes présentes. Il a été élaboré, après chaque séance d'observation, un rapport démontrant les comportements observés et les perceptions de l'observatrice liées aux faits. Dans les familles de jumeaux, l'accent a été plus spécialement mis sur les phénomènes suivants: $I^{\prime}$ assistance individuelle mère-jumeaux; I'assistance d'ensemble mère-jumeaux; La dispute de prise dans les bras/attention maternelle; I'assistance père-jumeaux, la relation intra-paire de jumeaux.Quant aux relations triangulaires impliquant les co-jumeaux et leurs parents, leurs analyses reposent sur les théories des questions oedipiennes selon Freud et Klein. Dans les familles soumises à cette étude, au-delà du triangle oedipien fils-mère-père, quatre autres formes de relations triangulaires ont été perçues.

Mots-clés: complexe d'Oedipe, jumeaux, relations objectales. 


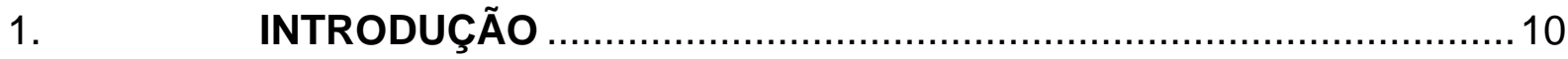

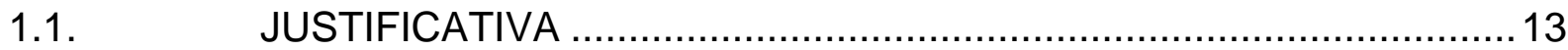

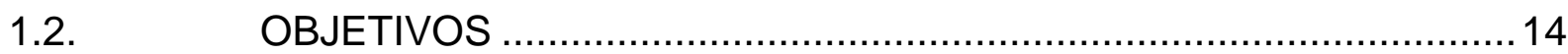

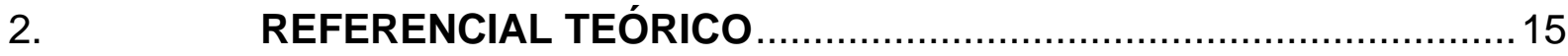

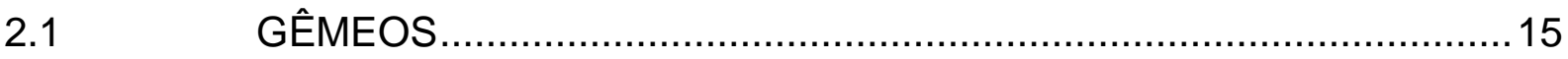

$2.2 \quad$ RELAÇÕES OBJETAIS FRATERNAS …........................................

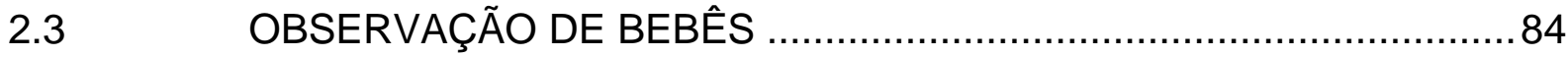

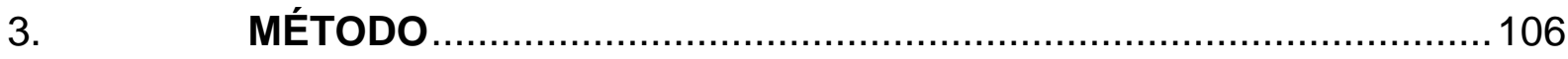

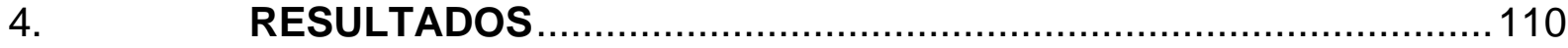

$4.1 \quad$ ATENDIMENTO INDIVIDUAL MÃE-GÊMEOS ...............................113

4.2 ATENDIMENTO CONJUNTO MÃE-GÊMEOS ................................. 125

4.3 DISPUTA DO COLOIATENÇÃO MATERNA ..................................132

4.4 ATENDIMENTO PAI-GÊMEOS ……....................................... 134

4.5 RELACIONAMENTO INTRA-PAR DE GÊMEOS ….........................137

4.6 PECULIARIDADES DO ATENDIMENTO MÃE-GÊMEOS .................144

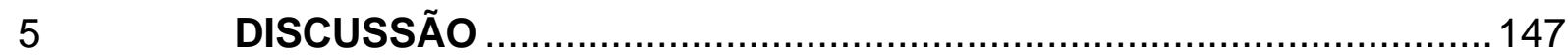

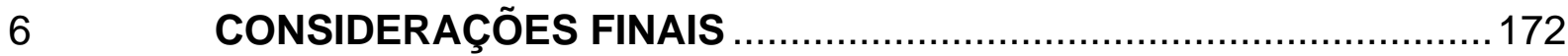

REFERÊNCIAS 


\section{INTRODUÇÃO}

Os gêmeos sempre me atraíram! A tal ponto que, em minha infância, competia com as outras crianças a conquista das "bananas felipe" que encontrava na fruteira, acreditando que, se comesse aquelas frutas que vinham em pares na mesma casca, poderia vir a ter filhos gêmeos.

O assunto trazia, de um lado, encantamento e, de outro, temor, pois desejava e, ao mesmo tempo, temia ser contemplada com filhos gêmeos.

O tempo passou e, na segunda gravidez, tornei-me mãe de gêmeos. A partir de então, o que parecia "só mistério" tornou-se realidade e passei a vivenciar situações que me levaram a uma infinidade de questionamentos.

Desde o momento em que desconfiei da gravidez, achei que estava diferente de quando tive o primeiro filho. A barriga aparecendo muito rápido, enfim...

Procurei uma ginecologista e disse a ela que eu provavelmente tivera algum sangramento, embora grávida, ou havia mais de um bebê ali. Ao ouvir a história, logo me encaminhou para a ultra-sonografia e foi constatado haver apenas um feto com seis semanas de gestação. Ao completar cinco meses, fiz nova ultra-sonografia e o médico anunciou a surpresa: gêmeas! Fiquei com a impressão de que havia apenas atrasado a notícia, pois eu parecia saber que eram dois bebês desde o início!

A partir de então, vivi uma gama de emoções, em que alegria e medo me invadiram! Os cuidados com a gestação foram redobrados, pois a médica alertava sobre as complicações que poderiam surgir numa gravidez considerada de 
alto risco, pelo fato de ser gemelar. Foram três meses de repouso absoluto, embora aparentemente nada houvesse de anormal.

A única diferença da gravidez anterior era que me sentia "super grávida", alvo de atenção de todos os que conviviam ao meu redor.

O nascimento dos bebês trouxe novas emoções, visitas mil, todos maravilhados com as gêmeas que nasceram enormes! Enfim, muita alegria!

Mas, nem tudo eram flores! O trabalho para cuidar de dois bebês ao mesmo tempo era imenso. A angústia vivida, ao me sentir impossibilitada de atender as duas filhas ao mesmo tempo, era indescritivel. Por mais que houvesse pessoas disponíveis, muitas vezes os bebês pareciam requisitar apenas a minha atenção e só se acalmavam sob meus cuidados!

Busquei na literatura, tanto leiga quanto psicológica, algo que esclarecesse minhas perguntas e poucas informações encontrei. Assim, iniciei uma trajetória de pesquisa, como docente da Universidade Estadual de Londrina, onde realizei alguns projetos tentando conhecer o universo dos gêmeos.

Inicialmente, queria saber a partir de quando os bebês gêmeos começam a interagir entre si. Pretendia fazer observações de gêmeos recémnascidos em situação natural, entretanto o projeto não foi aprovado, pois meus colegas de departamento consideraram impossível encontrar os seis pares de gêmeos recém-nascidos que planejei estudar!

Acabei desenvolvendo outros trabalhos visando: observar as interações intra-par de gêmeos em situação de brinquedo; conhecer a opinião de pais e professores a respeito das características dos gêmeos; comparar a forma como pais e professores cuidavam de gêmeos e irmãos não-gêmeos com idades 
próximas.

Enquanto as pesquisas eram desenvolvidas, havia comentários por parte de meus colegas docentes questionando sobre a importância de se estudarem gêmeos. Logo realizei um estudo sobre a incidência de nascimento de gêmeos na cidade de Londrina, o qual deu origem a um banco de dados sobre gêmeos que, na época, estavam na faixa de zero a quinze anos de idade. Foram catalogados cerca de mil pares de gêmeos a partir dos registros de nascimento localizados nos Cartórios de Registro Civil e, em seguida foram entrevistados os pais de 415 pares de gêmeos que conseguimos encontrar.

As entrevistas englobavam dados objetivos sobre condições de gestação, parto, amamentação e grau de semelhança entre os gêmeos, segundo a percepção dos pais e de obstetras. Ao longo da coleta de dados, os pais falavam espontaneamente a respeito das dificuldades que encontravam para cuidar de dois bebês ao mesmo tempo. A partir disso, resolvi elaborar um projeto no qual os pais participavam de grupos, onde compartilhavam suas vivências com os filhos gêmeos.

Os estudos duraram cerca de quinze anos, meus questionamentos continuavam em grau elevado. Várias coisas vinham a minha mente, mas o principal continuava sendo como a família, e especialmente a mãe, lida com dois bebês ao mesmo tempo. Os relatos dos pais eram sempre mais efusivos quanto às dificuldades por eles encontradas ao longo do primeiro ano de vida.

Paralelamente ao trabalho de pesquisa, participei do curso de Observação de Bebês - modelo Esther Bick, que muito contribuiu como inspiração para esta tese. 


\subsection{JUSTIFICATIVA}

O contato com os gêmeos, durante mais de duas décadas, levoume a várias reflexões sobre o fato de as relações entre cada gêmeo e seus pais apresentarem características diferentes daquelas vivenciadas pelos bebês singulares (quando nasce um bebê em cada gestação), especialmente nas relações triádicas.

Há vários anos tenho questionado os psicanalistas, nos cursos e eventos em que o Complexo de Édipo é abordado, a respeito das nuances do fenômeno em gêmeos e até o presente momento não encontrei respostas esclarecedoras. Os profissionais muitas vezes respondiam não haver diferenças e/ou, após uma reflexão mais profunda, acabavam dizendo não conhecer ainda estudos/conclusões a respeito. Assim, o tema parece ainda ser pouco estudado e merecedor de uma atenção especial.

Voltando às idéias do meu "projeto inicial", considero de suma importância observar e procurar entender o desenvolvimento dos gêmeos durante o primeiro ano de vida, sabendo agora que o índice de nascimentos gemelares é alto, que as famílias têm muitas dúvidas sobre como atendê-los, que o universo dos gêmeos parece ser diferente do dos bebês singulares e que existem poucos trabalhos a respeito do assunto na literatura psicológica. 


\subsection{OBJEtIVOS}

Observar e descrever as relações objetais triangulares entre os gêmeos e seus pais, durante o primeiro ano de vida;

analisar a possibilidade de a triangulação edípica ocorrer prioritariamente entre o par de gêmeos;

verificar se a "presença real" do co-gêmeo poderia exacerbar a vivência como "terceiro excluído" entre os gêmeos. 


\section{REFERENCIAL TEÓRICO}

\subsection{GÊMEOS}

O estudo de gêmeos, na Psicologia, tem sido realizado de forma bastante restrita. Encontramos muitos estudos priorizando aspectos biológicos e até psicopatológicos, mas poucos são voltados para o desenvolvimento do psiquismo propriamente dito.

Zazzo (1986) mencionou diversos trabalhos sobre gêmeos na $1^{\text {a }}$. edição de seu livro publicada em 1960, em que se comparavam gêmeos e nãogêmeos visando decifrar a influência genética e/ou ambiental sobre características de personalidade, psicopatologias e questões biológicas diversas.

O que se verifica atualmente é uma gama de trabalhos semelhantes, ou seja, continua-se fazendo uso dos gêmeos para estudar a influência da hereditariedade sobre doenças, sejam elas de cunho biológico ou psíquico. Encontramos também, nos últimos cinco anos, alguns estudos mostrando a preocupação com a incidência de nascimentos múltiplos (BEIGUELMAN et al., 2001), com a evolução da gestação gemelar (AMARAL et al., 2003; ACÁCIO; DRUMONT; PEREIRA, 2005), com o óbito gestacional de um dos gêmeos (COSTA et al., 2002; MARQUES; RUDGE, 2002), com fatores perinatais (CAMANO; FAVA; 
SOUZA, 2001), com a psicopatologia (CAMARGO; MONTEIRO; TONIDO, 2002; CROW; THIMOTHY, 2004), com o temperamento (GUZZO; ITO, 2002), entre outros.

Algumas pesquisas parecem demonstrar preocupação não só com a maior incidência de gestações múltiplas, provavelmente em função da possibilidade de diagnóstico precoce através de ultra-sonografia, seguido de maior cuidado com as gestantes, como também com os tratamentos contra a infertilidade que têm favorecido o aumento da incidência de gêmeos.

Entretanto, há raras referências abordando aspectos da relação intra-par de gêmeos, interação entre pais e gêmeos, questões educacionais, etc. Em outras palavras, fica a impressão de que os gêmeos têm sido utilizados para estudar "n" questões bio-psíquicas, mas existem poucos pesquisadores buscando compreender o que se passa no "universo dos gêmeos" a fim de entender a qualidade das relações intra-par bem como a relação entre os gêmeos e seus respectivos cuidadores.

Ao refletir sobre o tema, é possível imaginar que as vivências de gêmeos e não-gêmeos são distintas, mas também deve haver diferenças significativas entre os monozigotos ${ }^{1}$ e os dizigotos ${ }^{2}$, assim como entre os dizigotos de sexos iguais ou diferentes! Entretanto, no relacionamento entre os gêmeos e seus pais, o "simples fato" de nascerem dois ou mais bebês numa só gestação deve provocar diferenças drásticas no relacionamento pai-mãe-filho, independentemente de o par de gêmeos ser monozigoto ou dizigoto.

\footnotetext{
${ }^{1}$ Monozigoto: também chamado de gêmeos univitelinos ou idênticos, provenientes de apenas uma célula-ovo.

${ }^{2}$ Dizigoto: gêmeos provenientes de duas células-ovo distintas, também nomeados como bivitelinos.
} 
Zazzo (1986, p. 118-9) referiu-se aos conceitos do duplo e do par, como formas de pensar sobre os gêmeos. A noção do duplo remete à consciência de si mesmo, e no meio de uma implicação recíproca com a imagem de outro, a partir de uma confusão primitiva. Já a noção de par é bastante diferente, pois considera a dualidade supra-individual, na qual se opera o desdobramento de si mesmo e do outro - "du moi et du toi, par le même jeu de miroir, par la même dialectique d'opposition et d'identification, le dédoublement intime que est conscience de soi” (ZAZZO, 1986, p. 118). Assim, o que se percebe é que o par é a expressão objetiva do duplo, condição de sua gênese, mas também de suas flutuações ao longo da vida.

O autor mencionado nos lembrou da existência de diversos pares (mãe-filho, amigos, amantes) que se formam a partir de diferentes origens. A diversidade criada pelo par é função da diversidade anterior, que já existia, sendo dificilmente divorciada da história pregressa. O par de gêmeos idênticos implica uma experiência de valor inestimável pelo fato de a diversidade ser praticamente inexistente em sua origem - principalmente genética. Assim, verifica-se, na literatura, o quanto esses pares de gêmeos monozigotos são considerados como sujeitos valiosos para pesquisas sobre o desenvolvimento de aspectos psíquicos, pois, sendo a herança genética idêntica, as diferenças intra-par seriam causadas pela influência ambiental.

Entretanto, Zazzo chamou a atenção para a diferenciação e equilíbrio variáveis entre os vários pares de gêmeos. Levantou a questão de que cada par de gêmeos também se relaciona com outros pares que certamente interferem nas relações vivenciadas pelos co-gêmeos com outras pessoas. Logo, 
para que cada elemento do par de gêmeos se desenvolva, haverá uma infinidade de contatos, melhor dizendo de outras relações objetais, interferindo também.

Por outro lado, se o par ultrapassar e informar o indivíduo, este poderá se evadir - mais ou menos - pela multiplicidade de pares onde ele está preso, pelas variantes inomináveis de imagens que o prendem a si mesmo. De tal sorte, a autonomia da pessoa, contraditoriamente, engana e oprime dentro do par! Assim, cada pessoa se constitui por suas experiências em sucessivos engajamentos e des-engajamentos em relação a outras duplas do seu meio familiar, mas também no conjunto maior de relacionamentos.

Além dos aspectos mencionados por Zazzo, acho importante considerar a maneira como cada co-gêmeo percebe e reage às interações intra-par, bem como aos relacionamentos com outras pessoas do seu meio. Só assim é possível ter uma idéia de como e por que as individualidades de cada ser, em especial gêmeos, constituem-se.

É Zazzo (1986, p. 119-120) quem fala sobre o tema, na tradução do seu texto, abaixo colocada:

\begin{abstract}
Um estudo sério das relações inter-individuais exigiria que se estabelecesse uma descrição concreta de par e a classificação de suas formas diversas de equilíbrio e a hierarquia de suas preferências, de suas forças de diferenciação e de alienação. No entanto, no momento decisivo da interpretação, este estudo corre o risco de ser completamente deturpado caso este tenha como modelo privilegiado o casal secundário, isto é, a conjunção de dois indivíduos nitidamente diferenciados na consciência que cada um tem de si mesmo, e mais ou menos conscientes dos complementos de ser, dos dotes e das satisfações que eles esperam um do outro.
\end{abstract}

Um outro aspecto mencionado pelo autor é que, nos gêmeos, o par é formado por duas pessoas de mesma idade desde o início da vida, ao passo que, nos demais pares (mãe-filho, irmãos não-gêmeos, amantes, cônjuges), as idades 
são diferentes, sendo que muitas vezes pelo menos um dos parceiros é um adulto; presume-se, pois, que tenha consciência da existência de si mesmo, como indivíduo diferente do outro.

Zazzo fez também alguma referência à imagem do outro, "l'image intériorisée d'autriu" (1986, p. 123) construída a partir das relações com as pessoas do meio externo. É preciso, então, refletir sobre a maneira como se estabelecem as relações objetais intra-par de gêmeos, bem como entre cada co-gêmeo e as outras pessoas de seu meio para melhor compreender o "universo dos gêmeos".

Zazzo chegou a falar sobre a patologia do duplo como um meio para compreender o que se passa com os gêmeos e, especialmente, os chamados idênticos. Isso levou-me a pensar nos escritos de Freud sobre as questões do duplo, no texto "O Estranho", bem como no texto de Bion (1994) sobre "O Gêmeo Imaginário".

Freud $^{3}$ falou a respeito da estranheza que o fenômeno do "duplo" causa nas pessoas, enfatizando que aparece sob diversas formas e graus de desenvolvimento, em diferentes momentos da vida seriam aqueles indivíduos que parecem ser iguais, levando-nos até a pensar na possibilidade de que se comunicassem por telepatia, como se ambos possuíssem conhecimentos, sentimentos e experiências em comum. Além disso, "o sujeito identifica-se com outra pessoa, de tal forma que fica em dúvida sobre quem é o seu eu (self), ou substitui o seu próprio eu (self) por um estranho. Em outras palavras, há uma duplicação, divisão e intercâmbio do eu (self)" (FREUD 1919b/1974, p. 292-293).

\footnotetext{
${ }^{3}$ Preferi colocar a data da publicação original dos textos de Freud e Klein, visando melhor situar a época em que os textos foram publicados.
} 
Pensando no relacionamento intra-par, é possível questionar se a identificação com o co-gêmeo poderia ser tão grande a ponto de levar cada bebê gêmeo a imaginar que a mãe cuida de uma parte de si mesmo quando faz o holding (WINNICOTT, 1983) do co-gêmeo, por isso aguardando pela sua vez de ser cuidado sem grandes reclamações. Além disso: poderia essa identificação com o co-gêmeo poderia para relações objetais narcísicas intra-par de co-gêmeos?

Considerando ainda a questão do duplo, será possível que a presença dos gêmeos, principalmente monozigóticos, poderia mobilizar sentimentos narcísicos nos pais, levando-os a considerar os dois co-gêmeos como réplicas e não como seres individuais? Para tanto, vale lembrar que

Originalmente, o 'duplo' era uma segurança contra a destruição do ego, uma 'enérgica negação do poder da morte', como afirma Rank; e, provavelmente, a alma 'imortal' foi o primeiro 'duplo' do corpo. (...) Tais idéias, no entanto, brotaram do solo do amor-próprio ilimitado, do narcisismo primário que domina a mente da criança e do homem primitivo. Entretanto, quando essa etapa está superada, o 'duplo' inverte seu aspecto. Depois de haver sido uma garantia da imortalidade, transforma-se em estranho anunciador da morte. (FREUD, 1919b/1974, p. 293-294)

A percepção de dois filhos como réplicas estaria favorecendo o medo da morte de cada um na mente da mãe? Ao percebê-los como dois indivíduos, a mãe precisaria fazer um luto pela "não igualdade" para então ter que se haver com as duas identidades singulares? Qual seria o efeito disso na mente dos gêmeos?

Outro aspecto abordado por Freud é que a idéia do 'duplo' não necessariamente desaparece após o narcisismo primário, mas pode receber significados diferentes, tais como "a função de observar e de criticar o eu (self) e de exercer uma censura dentro da mente, e da qual tomamos conhecimento como 
nossa “consciência'” (FREUD, 1919b, p. 294). Essa consciência (moral) compreende o ideal de ego, portanto não seria o duplo, mas sim uma evolução para o narcisismo secundário. Nas situações mais patológicas, tais como no caso de delirios de observação, a pessoa poderia funcionar como se houvesse um duplo de si mesmo, ao qual atribuiria, dentre outras, a função de auto-observação, que estaria além do narcisismo primário.

Ao estudar gêmeos durante o primeiro ano de vida, poderíamos perceber algo que fosse equivalente a um gêmeo ser observado pelo seu co-gêmeo como um duplo de si mesmo?

O fato de cada gêmeo conviver com o seu co-gêmeo, no útero, poderia levar os gêmeos a funcionar como duas partes de um mesmo ser? Até que ponto seus pais e, especialmente, a mãe lida com os gêmeos como se fossem apenas partes de uma pessoa?

O fenômeno do duplo era percebido como "algo estranho" por Zazzo (1986, p. 125), a ponto de levantar a hipótese de que a especificidade do homem-gêmeo não é uma qualidade irredutível à mentalidade do homem-singular, mas que é um desvio - deviation.

Visando compreender as vicissitudes do duplo e do par, Zazzo realizou diversos estudos a respeito das peculiaridades dos gêmeos idênticos, abordando aspectos tais como: inteligência, linguagem, socialização, mitos e ritos gemelares. Dedicou um capítulo de seu livro, já mencionado, ao estudo da personalidade dos gêmeos, tendo questionado muito a capacidade de um singular compreender, de fato, a gemelaridade. Passeou sobre as questões do duplo, enfatizando que, até mesmo para os gêmeos, é difícil admitir a existência de um duplo de si mesmo. 
Sob tal ponto de vista, o que se percebe é que, na verdade, não deve existir uma barreira intransponível entre as pessoas singulares e os gêmeos, pois os problemas são basicamente os mesmos. Conforme a tradução que se segue, do livro de Zazzo (1986, p. 261-2): "Mas os problemas são fundamentalmente os mesmos. A dialética do eu e do outro. A conquista da autonomia. Por mais original que ele seja, o estado de gêmeo não é estranho à condição humana".

Os estudos desse autor implicavam primordialmente em questionários, nos quais cada co-gêmeo era investigado separadamente sobre diversos assuntos. Quando se tratava de pesquisas com crianças, geralmente a mãe fornecia as informações. Dentre os aspectos investigados, chamou a minha atenção a questão da "confusão" vivenciada pelos gêmeos, a qual pode ser revelada nas crianças que, até os cinco anos de idade, usavam os pronomes na primeira pessoa do plural (on, nous) em vez da primeira do singular (je, moi). Em certos casos, os co-gêmeos falavam "meu-teu" (mon-tien) de forma tal que pareciam ter dificuldade de se assumir como Eu sendo diferente do outro - teu, seu. (p. 280)

O autor acreditava que a confusão de formas pronominais é sem dúvida um efeito do par, um obstáculo que o duplo real opõe à formação do duplo mental, da consciência de si. Entretanto, defendeu a idéia de que parte dessa confusão pode ser provocada pelo próprio ambiente, na medida em que as pessoas se dirigem aos gêmeos de forma confusa, tratando-os habitualmente como uma dupla. Geralmente a criança responde ao ser chamada pelo próprio nome antes de completar um ano de vida, sendo que os gêmeos, muitas vezes, têm dificuldade em reconhecer o próprio nome, confundindo-o com o do co-gêmeo até muito mais 
tarde. Tudo isso, certamente, dependendo da maneira como são tratados pelos seus cuidadores.

Zazzo (1986, p. 281) encontrou 20 pais, num total de 500, que lhe confidenciaram usar pulseiras ou outros artifícios para diferenciar os co-gêmeos e evitar maiores confusões. Sobre tais práticas, quando escrevi o livro Conversando sobre Gêmeos (VIOTTO, 1999), sugeri que as famílias lançassem mão de artifícios semelhantes, sendo que naquela época eu desconhecia o texto comentado.

Outro fato mencionado por Zazzo diz respeito aos nomes semelhantes colocados nos co-gêmeos e também aos apelidos que vão sendo dados ao longo da vida. Os nomes muitas vezes têm diferenças de uma letra, favorecendo mais ainda as confusões de identificação. Muitos adultos se referem aos gêmeos como "o bebê", sem nomear de forma correta cada criança. Os próprios gêmeos por vezes criam um mesmo apelido para ambos: "On nous appelait popo. Alors je l'appelais popo e til m'appelait popo." (ZAZZO, 1986, p. 282). Enquanto os bebês singulares respondem ao próprio nome por volta de 6 a 9 meses, os gêmeos acabam diferenciando seus nomes próprios por volta de 2-3 anos, havendo casos que se prolongam até os 5 anos de idade.

Tais fatos dão notícia das confusões vivenciadas pelos gêmeos e, possivelmente, de comprometimentos psicopatológicos futuros!

Outro aspecto mencionado por Zazzo (p. 285) são as substituições que os co-gêmeos fazem entre si em situações de sala de aula e até mesmo nos relacionamentos amorosos são momentos em que, por motivos diversos, um dos co-gêmeos se faz passar pelo outro.

Zazzo referiu-se também aos antagonismos existentes entre os 
gêmeos idênticos: uma forte ligação afetiva, reciprocidade intensa e, ao mesmo tempo, ciúmes que aparecem em determinadas circunstâncias. Falou sobre alguns fenômenos que são mais intensos e freqüentes nos gêmeos idênticos, tais como sincretismos de linguagem e pensamento, chegando até a sugerir que reações corporais poderiam ser caracterizadas como sinais de manifestações parapsicológicas, tais como a comunicação de pensamentos e telepatia. Sobre tais assuntos, descreveu alguns relatos de gêmeos e de mães de gêmeos.

Não pretendo aqui estudar esse tipo de assunto, entretanto achei interessante comentá-los porque muitas vezes são mencionados como crendices sobre o relacionamento gemelar e que não foram ainda estudados de forma mais efetiva. Tudo isso é bastante significativo, a meu ver, como ilustração sobre a necessidade de realização de estudos observacionais sérios a respeito do que se passa nas relações intra-par de gêmeos, entre os co-gêmeos e seus cuidadores.

A literatura científica sobre o assunto é bastante restrita. No Brasil, encontramos poucos livros publicados sobre gêmeos, dentre eles: Saldanha (1980), que abordou questões relativas à herança genética e ambiental, enfatizando as vantagens e desvantagens do uso de gêmeos para tais estudos; Machado (1980) escreveu um pequeno livro no qual falou sobre as vicissitudes da gemelaridade, ressaltando a questão da individualidade, rivalidades e disputas entre os cogêmeos, bem como o relacionamento mãe-gêmeos.

Machado ressaltou, especialmente, a necessidade de a mãe se relacionar com os filhos, considerando cada co-gêmeo como um ser único e não como "um bloco de dois filhos" (p.44). Acreditava que, se assim agir, cada criança poderá se beneficiar e se individualizar de forma mais satisfatória. Outro aspecto mencionado pela autora é a freqüência com que os gêmeos são comparados pelas 
outras pessoas e a necessidade de a mãe minimizar tais situações, que podem se tornar problemáticas, ressaltando as características de cada gêmeo. "Ao fazer isso, os pais e familiares estarão mostrando tanto às crianças como às pessoas que fizerem tais comentários que seus filhos têm méritos por si próprios e por motivos diferentes, e não com base em padrões comparativos" (p. 43). Assim, situações de rivalidade e de comparações poderiam ser amenizadas.

E por falar em comparações, encontrei o texto de Gibson (2002) que relata uma experiência que tinha como objetivo explorar a influência de variantes culturais, diferenças raciais e pobreza sobre a capacidade da mãe de cuidar dos seus bebês gêmeos. A coleta de dados consistiu em observações realizadas na residência da família durante dois anos. Chamou a minha atenção, de forma especial, o fato de os irmãos mais velhos geralmente questionarem a observadora a respeito de "quem é quem" no par de gêmeos, além do fato de serem chamados como "este" ou "aquele" em vez dos nomes próprios de cada cogêmeo. Outro aspecto mencionado pela autora foi o da mãe que oferece pouca ajuda para diferenciar os co-gêmeos, tratando-os muitas vezes como um grupo, ou seja, nomeando-os como "eles" em lugar de falar os respectivos nomes. Embora a própria observadora fosse percebendo diferenças entre os bebês gêmeos, a mãe continuava a falar com eles em bloco. Lá pelo segundo mês de vida, a mãe começou a comparar a cor de pele de ambos, tentando assim diferenciá-los. Ao longo do primeiro ano de vida, embora a mãe continuasse tendo alguma dificuldade para identificá-los e chamar os gêmeos pelos próprios nomes, enfatizava que a competição entre os co-gêmeos não era uma boa coisa! Entretanto, a competição intra-par era constante: "The boys competed with each other for a toy or food. Linda slavishly tried to create equality between them. They also competed for the attention 
of the older children in what Linda called 'showin' off'. " (p.63). A questão da competição intra-par de gêmeos me parece ser algo bastante comum, tal qual mencionei anteriormente (VIOTTO, 1999).

É possível que a competição intra-par seja exacerbada pelo fato de cada gêmeo buscar não só a atenção materna, mas também a diferenciação, de tal modo que possam ser percebidos de forma diferente e, logo, identificados pela mãe nas diversas situações.

Miglio (1995, p. 9) mencionou o livro de Zazzo (1984) - Le Paradoxe des Jumeaux - para explicar que o paradoxo dos gêmeos consiste no fato de o gêmeo fisicamente idêntico não ser idêntico do ponto de vista psicológico. A autora destaca também a importância do método de gêmeos para estudar o efeito do ambiente e da genética sobre o desenvolvimento psicológico, mencionando inclusive os estudos sobre o "duplo" e a "cópia” realizados por Zazzo e também por Freud. Ao fazer as suas pesquisas, Miglio buscava compreender a essência do "Ser", para tanto analisando, dentre outras coisas, o processo de individuação entre os gêmeos idênticos e fraternos. As pesquisas por ela conduzidas consistiam em questionários que visavam compreender "quem sou eu" do ponto de vista de cada co-gêmeo, buscando descobrir aspectos da "Identitá Sociale (IS)" e de "Atribute Personali (AP)" (p.71).

Miglio acreditava que os gêmeos se constituem como uma unidade existencial complexa, idéia compartilhada por outros autores, por ela citados, tais como Burlingham (1952), que usou o conceito de "gang em miniatura", e Gedda (1951), que mencionou o conceito de "sociedade intragemelar" (società intrageminale).

Considero essas idéias tão importantes que penso ser necessário 
investigar desde quando e como os gêmeos passam a funcionar como se fossem uma verdadeira "equipe". A maioria das pesquisas encontradas na literatura foi realizada por meio de questionários e/ou entrevistas, bem como de testes psicológicos aplicados em gêmeos adolescentes ou adultos. Entretanto, fica a dúvida a respeito do que acontecia com os gêmeos no início da vida, para então termos uma idéia de como se relacionavam entre si, com a mãe e demais cuidadores. Acredito ser a observação direta a melhor estratégia para conduzir estudos sobre o assunto, pois só assim será possível saber se os próprios cogêmeos se fecham em seu "grupo-gêmeos" ou se o meio ambiente é que os percebe como unidade e assim os aprisiona no par.

Miglio ressaltou que o estudo de Klein sobre as relações objetais poderia auxiliar na compreensão do que se passa no processo de individuação dos gêmeos. Segundo a autora, Klein tende a atribuir eventual distúrbio no processo de individuação a uma relação difícil entre o gêmeo e sua mãe, sendo tal relação constantemente mediada pelo co-gêmeo. Conforme se percebe na tradução do seu texto, abaixo colocada:

Assim os sentimentos de rivalidade e hostilidade que estão frequentemente presentes nos gêmeos podem ser atribuídos ao fato de precisar dividir com o co-gêmeo a mãe, primeira fonte de satisfação e de gratificação (Zazzo, 1984). Trata-se de uma hipótese fundada, que, porém não exclui as conseqüências, que são positivas ou negativas, do relacionamento direto com o co-gêmeo, relacionamento que objetivamente é considerado mais primitivo do que aquele com a mãe. (MIGLIO,1995, p, 58-59)

Percebe-se que a autora considera a relação com o co-gêmeo tão essencial quanto a relação inicial com a mãe para compreender a formação da identidade em cada co-gêmeo.

Fabozzi (1995) descreveu o difícil relacionamento vivenciado por 
uma paciente (S) gêmea, a qual, quando ainda era bem pequena, falava com sua mãe através do seu co-gêmeo, pois a mãe não entendia o que ela estava dizendo. É possível fazer conjecturas a respeito de como essa mãe se relacionava com os filhos gêmeos, como também a forma como a paciente (S) se sentia fusionada com o co-gêmeo a ponto de não assumir a sua própria individualidade.

Fabozzi (1995, p. 159-160) mencionou o artigo de Athanassiou (1986) que falava sobre a incapacidade da mãe em diferenciar suficientemente os dois gêmeos, considerando o vinculo simbiótico com a mãe, onde o gêmeo amamentado vivenciava a raiva e a rivalidade em relação ao co-gêmeo com o qual se confundia e acabava então por se constituir como um elemento parasita que perturbava a intensidade, a plenitude e o potencial de evolução psíquica da relação do bebê com o seio e a mãe.

Fabozzi continuou a narrativa do caso, mencionando a evolução psíquica e o processo de individuação vivenciado pela paciente, passando por situações onde, na transferência, temia viver de forma simbiótica com o terapeuta. Posteriormente, ao desejar e conseguir engravidar, temia viver com o bebê e 0 marido uma relação semelhante ao que ocorreu entre ela, o co-gêmeo e sua mãe.

Dentre os autores brasileiros, encontrei Jabbour e Marques (2000) que escreveram um livro relatando sua pesquisa realizada como trabalho de conclusão de curso de graduação em Psicologia. Ao longo do texto, falaram sobre os mitos "Rômulo e Remo", "Castor e Pólus" e "Anfião e Zero", ressaltando aspectos ligados à cooperação, competitividade e simbiose intra-par de gêmeos. A pesquisa foi realizada através de questionário aplicado a 20 pares de gêmeos idênticos, versando sobre a maneira como cada indivíduo se percebia, semelhanças no ambiente escolar e social, vivências de situações de separação motivadas por 
doenças, sentimentos provocados pelo fato de serem confundidos pelas pessoas, vestuário igual ou diferente, etc. A análise dos dados ocorreu em termos de porcentagem de respostas, seguida por comentários onde as autoras enfatizavam a necessidade de os pais se preocuparem em promover condições para as pessoas serem capazes de identificar cada co-gêmeo e tratá-los de forma mais individualizada. O valor maior do livro supracitado está no fato de uma das autoras ser gêmea idêntica e a outra, "singular". De tal forma as análises qualitativas apresentadas parecem refletir a visão proporcionada pela "vivência gemelar", pois, quando comentam os achados de outros pesquisadores, como por exemplo, a vantagem de colocar os gêmeos em classes separadas desde a pré-escola, defendem a necessidade de mantê-los juntos por mais tempo. Nesse caso, ficou a impressão de que, em certos momentos, fundamentaram-se mais na vivência pessoal da co-gêmea Jabbour do que na pesquisa teórico-prática que realizaram...

Tudo isso me faz pensar na necessidade de estudar a questão da gemelaridade sob diferentes prismas, para que se possa ter uma idéia mais completa do fenômeno. Acredito que, independentemente da zigosidade, é preciso muita observação das vivências intra-par de co-gêmeos e entre os gêmeos e seus cuidadores para que se tenha uma idéia de como o processo de individuação e, logo, do desenvolvimento da identidade em gêmeos se processa.

Encontrei poucos estudos a respeito do desenvolvimento da personalidade em gêmeos, entretanto foi possível localizar algumas contribuições interessantes que passo a comentar a seguir.

O artigo de Joseph (1975) traz um exaustivo levantamento bibliográfico a respeito de pesquisas que usaram a situação psicanalítica tradicional como base de pesquisa. $O$ autor descreveu alguns estudos onde os gêmeos foram 
analisados por dois analistas independentes e o material coletado foi relatado a um terceiro analista. Em outros momentos, descreveu estudos onde os pesquisadores (BENJAMIN et al., 1960) estiveram envolvidos num estudo longitudinal de gêmeos e suas respectivas famílias, onde verificaram a importância da identificação materna ou paterna com um dos elementos do par de gêmeos e as implicações para o desenvolvimento de cada co-gêmeo.

Dentre os vários estudos mencionados por Joseph, chamou a minha atenção, de modo especial, o seguinte comentário:

Estimulados pelos primeiros relatórios da literatura, os psicanalistas empreenderam um certo número de projetos de pesquisa a envolver quer a psicanálise de gêmeos individuais, quer de uma série de gêmeos estudados por métodos psicanaliticamente orientados. Constitui observação interessante que, de modo coerente com as tendências psicanalíticas mutantes, a ênfase nas descobertas nos estudos de gêmeos deslocou-se dos componentes edipianos para os pré-edipianos, nos relatórios de gêmeos individuais. ... Onde 0 interesse foi os relacionamentos objetais dos gêmeos, deu-se ênfase ao desdobramento de triângulos edipianos, complicados pela existência simultânea de um rival contemporâneo, bem como pela do rival parental tradicional. Outros estudos sobre o impacto das relações objetais no caso de gêmeos enfatizaram a reação "geminada" (Joseph e Tabor), a favorecer uma acentuação da interidentificação mútua e o fracasso da separação individuação entre os membros de um par de gêmeos. (1975, p.105)

Encontrei alguns textos nos quais se verifica que, embora sendo fruto de um fenômeno natural, os gêmeos vivenciam situações diferentes dos singulares desde o útero materno. Piontelli (1995) nos lembra que Freud afirmou haver muito mais continuidade entre a vida intra-uterina e a primeira infância do que a impressionante cesura do nascimento permite saber. A mesma autora relatou observações intra-uterinas realizadas através de ultra-sonografia, bem como o acompanhamento às crianças durante os primeiros 4 anos de vida, podendo 
constatar que alguns padrões de comportamento, iniciados na fase intra-uterina, mantiveram-se após o nascimento. Verificou que o gêmeo ativo tenta tocar o outro, enquanto o passivo recua dessa aproximação, ainda no útero. Mencionou um caso de gêmeas que se estapeavam no útero e continuavam a se agredir nos primeiros anos de vida, expressando ódio mortal e intolerância mútua; noutro caso, um casal de gêmeos, Luca acariciava a cabeça de Alice através da membrana que os separava, sendo que a mesma atividade foi observada aos dois anos quando brincavam enrolados numa cortina.

Embora exista um grande número de gêmeos que são bem sucedidos, encontramos vários autores (ATHANASSIOU, 1986; BIALE, 1989; LEWIN,1994) que enfatizaram as peculiaridades encontradas no desenvolvimento dos gêmeos, as quais podem desencadear comprometimentos em termos afetivoemocionais. Por outro lado, Szejer e Stewart (1997, p. 102) mencionaram o sentimento de catástrofe que se abate sobre a mulher ao saber da gravidez múltipla, enfatizando que o sentimento será "tanto maior quanto mais numerosos forem os filhos anunciados".

A fim de refletir sobre as características da gemelaridade, convém lembrarmos que, ao engravidar, o casal se prepara para receber um bebê, no entanto, ao conceberem gêmeos, ambas as crianças poderão ser colocadas no mesmo locus afetivo e serem consideradas como se fossem partes de uma mesma pessoa.

Num outro extremo, podemos encontrar os casais que não suportam a idéia de ter tantos bebês de uma só vez, podendo ocasionar danos futuros profundos e talvez até irreversíveis nos filhos. Fato mencionado por KüblerRoss (2003, p. 9) a respeito do seu próprio nascimento, dizendo: 
... fui uma criança "indesejada". Não que meus pais não quisessem um filho. Eles queriam demais uma menina bonita, graciosa, pesando 4,5 quilos. Não esperavam trigêmeas, e, quando eu nasci, pesava menos de um quilo. Era muito feia, não tinha cabelo e fui realmente um enorme desapontamento para meus pais. Quinze minutos depois, nasceu a segunda menina, e, após outros vinte minutos, nasceu uma menina com três quilos, e então todos ficaram muito felizes. Mas eles teriam gostado de devolver as duas primeiras.

Portanto, passei pela tragédia de ter nascido trigêmea, uma tragédia enorme, que não desejo ao meu pior inimigo. Se você for uma trigêmea idêntica, isso é muito peculiar, porque você pode cair morta e ninguém vai perceber a diferença.

Winnicott (1982) ressaltou que é impossível a mãe satisfazer as necessidades imediatas de dois bebês ao mesmo tempo, assim deverá se conscientizar de que sua finalidade não deve ser tratar cada filho de maneira idêntica, mas tratá-lo como um ser único. É essencial que o tratamento dado a cada gêmeo permita que a totalidade e a unicidade de cada um alcance pleno reconhecimento.

Se considerarmos que a função de revêrie da mãe (BION, 1994) é essencial para que o ser humano tenha um bom desenvolvimento do seu aparelho mental, é possível imaginar o quanto a mãe de gemelares deveria ser bem instrumentada psiquicamente a fim de possibilitar o desenvolvimento ótimo de seus bebês. Sendo assim, é extremamente importante considerarmos a capacidade da mãe, ao compartilhar as vivências com seus gêmeos, de poder ajudá-los a compreender e nomear suas emoções de modo que, espelhando as suas angústias e alegrias, possa não só contribuir para a estruturação de suas identidades próprias, mas também incrementar o relacionamento com cada um, ajudando a diferenciar quem é quem e, assim, evitar a confusão de identidades.

Todavia, o que verificamos na realidade não é bem isso, pois o 
nascimento de gêmeos costuma interferir na dinâmica da família de forma bem mais intensa do que o nascimento de singulares, sendo comuns o aparecimento e/ou agravamento de dificuldades financeiras, distúrbios no relacionamento entre cônjuges, pais-filhos, etc.

Biale (1989) enfatizou a necessidade de profissionais das áreas de saúde estarem mais bem informados a respeito das peculiaridades dos gêmeos a fim de melhor atendê-los. Para tanto, sugere que alguns fatos (competição intrapar, desenvolvimento da identidade, desenvolvimento da linguagem, etc.) sejam considerados. Os fenômenos ressaltados por Biale são deveras importantes para a compreensão das características "normais" da gemelaridade, contudo é importante ressaltar ainda outras questões, tais como as levantadas por Vivienne Lewin (1994), que enfatiza o fato de o bebê gêmeo nunca estar sozinho com a mãe (já que, desde o útero, divide a "mãe barriga" com o co-gêmeo). Mesmo quando um dos bebês morre, ele continua presente na memória do co-gêmeo e da mãe. Segundo Lewin, o bebê no seio exclui o co-gêmeo, tanto da mãe quanto de si mesmo, fato que pode levar tanto a sentimentos de triunfo quanto ao receio de ataque pelo outro "excluídobebê invejoso". Em outro momento, o bebê, que nesse momento, desfruta o seio será o bebê excluído, com sentimentos de fúria e de rejeição. Logo, nesta situação, aparecem sentimentos de triunfo misturados com fúria e ansiedade, sendo difícil para o bebê estabelecer uma relação confortável com a mãe, em que a satisfação e a continência podem ser experimentadas. Verifica-se, então, que o relacionamento gemelar cria, para cada gêmeo, dificuldades específicas em seu desenvolvimento e talvez sentimento de culpa por estar vorazmente tirando o leite do co-gêmeo.

No caso de singulares, quando a mãe possui adequada capacidade para continência, o bebê pode se desenvolver e se separar dela, usando o 
relacionamento mãe-filho como um veículo para a formação de sua própria identidade. Em gêmeos, a presença de um outro bebê complica esse processo, pois cada criança enfrentará um conflito entre a relação gemelar e a necessidade de desenvolvimento pela identificação com a mãe.

Dentre os aspectos estudados por Biale (1989) acho importante ressaltar que os gêmeos prematuros recebem menos atenção materna do que os singulares prematuros, entretanto se desenvolvem de forma semelhante. Assim, a autora considera que o vínculo criança-criança poderia estar compensando a falta de atenção materna, aspecto também mencionado por outros autores (GOLDBERG, PERROTA, MINDER e CRNIC,1988, apud BIALE).

Biale enfatizou também que bebês prematuros apresentam um alto nível de atenção um ao outro, tanto física como emocionalmente. Confortam um ao outro por meio de intimidade física e chegam a solicitar atenção materna quando o co-gêmeo a recebe, por volta de quatro meses de vida. Além disso, afirmou que os gêmeos imitam o co-gêmeo $e$, de certa, forma regulam $o$ progresso no desenvolvimento de um em relação ao outro, sendo comum manifestarem fome e regularem o sono entre si com o aumento do grau de desenvolvimento.

Comportamentos agressivos intra-par de gêmeos são comuns e costumam se manifestar mais cedo do que nos singulares, sendo comuns os empurrões, pancadas e mordidas por volta dos oito a dez meses (BIALE, 1989). Tais manifestações agressivas constituem um problema para os pais e demais cuidadores por se tratar de crianças muito jovens, competitivas entre si, sendo difícil conter a agressividade e levar a criança a compreender a importância de não agredir fisicamente o co-gêmeo. 
Biale chamou a atenção para o desenvolvimento da linguagem e da personalidade dos gêmeos, ressaltando a circunstância especial de serem tanto "dois indivíduos" quanto uma "unidade". Lembrou que os gêmeos idênticos freqüentemente reagem à imagem deles próprios como um duplo (duo) antes de responderem à percepção de si mesmos, sozinhos no espelho. Lembrou também que, muitas vezes, os gêmeos usam os pronomes "eu" e "nós" ao se referirem a si mesmos, podendo ser analisados "como se" estivessem vivenciando problemas relativos ao desenvolvimento da identidade. Em relação a tais aspectos, a autora concorda com as conclusões de Zazzo sobre os mesmos temas.

É preciso considerar a possibilidade de haver a evolução patológica das identidades dos co-gêmeos, mas o fato de apresentarem certa confusão ao se nomearem pode estar refletindo apenas a questão de se sentirem ao mesmo tempo um singular e um membro da dupla, naquele momento específico. Por outro lado, pesquisas mais recentes mostram que tais características geralmente refletem a realidade dos gêmeos em ser um par. Então, o que parece ser confusão entre "eu", "você", "nós" e algumas vezes os próprios nomes, tem sido considerado há um certo tempo como referindo à identidade dupla dos gêmeos (MALMSTROM; SILVA, 1986, apud BIALE, 1989).

Biale (1989) comentou as diferenças percebidas especialmente em gêmeos monozigotos masculinos que costumam apresentar um significante risco de atraso no desenvolvimento da linguagem, fato que usualmente conduz à imaturidade quanto às habilidades interpessoais; no entanto não apresentou qualquer justificativa para o fenômeno. Ressaltou também a importância de o ambiente favorecer melhores condições para o desenvolvimento dos gêmeos, pois quando o par de gêmeos têm oportunidades limitadas para a interação com outras 
crianças antes de ingressar na pré-escola, frequentemente apresentam dependência excessiva de um em relação ao outro no período inicial de adaptação (HAY; O'BRIEN; JOHNSTON; PRIOR, 1984; HAY; PRIOR; COLLETT; WILLIAM,1987; apud BIALE, 1989).

Durante a infância, os gêmeos vivenciam dois processos de separação simultaneamente: (1) separação dos pais e (2) separação de cada um em relação ao outro (BIALE, 1989). Com frequência há um movimento de balanceamento entre os dois processos. Na fase de esforço interno para a independência e separação dos pais, os gêmeos estarão muito íntimos em relação ao outro, aparentando quase sempre serem uma "gang completa" para fazer travessura. Quando a separação dos pais está na fase calma, os gêmeos focalizarão o relacionamento deles, frequentemente procedendo com a questão da separação-individuação através de intenso combate e competição. Os gêmeos costumam apresentar um grau elevado de competição que raramente é observado em singulares.

O desenvolvimento de identidades separadas, ou seja, em pessoas razoavelmente saudáveis, requer um trabalho extra por parte dos pais, particularmente da mãe. Pelo fato de se identificarem vigorosamente um com o outro, eles podem perceber a mãe como interferindo no relacionamento deles, sendo até considerada desnecessária para eles. A capacidade para perceber a mãe como um continente dependerá da aceitação de cada um quanto à interferência dela no relacionamento gemelar (ATHANASSIOU,1986).

Lewin (1989) abordou o mesmo tema dizendo que se houver apenas um bebê e uma mãe com adequada capacidade para a continência, o bebê pode se desenvolver e se separar dela, usando o relacionamento com a mãe como 
um veículo na formação de sua própria identidade. Entretanto, com gêmeos, a presença do co-gêmeo complica este processo e cada bebê enfrentará um conflito entre a relação gemelar e uma necessidade de desenvolvimento através da identificação com a mãe. Lewin ressaltou ainda que, estando separados, há uma penetrante sensação de incompletude em gêmeos, uma constante busca por e preocupação com o outro, tanto se eles são gêmeos mono ou dizigóticos. Há também a possibilidade de sentimentos antagônicos tais como a presença de um desejo profundo pelo outro gêmeo e, ao mesmo tempo, um ódio intenso a ponto de alguns literalmente desejarem a morte do co-gêmeo como único meio aparente de livrá-los do parasita odiado. Onde há extensa identificação projetiva mútua entre os gêmeos, algum senso de separação está fragilizado e há uma confusão resultante entre self e objeto, entre gêmeo e co-gêmeo.

A esse respeito é interessante lembrar da história das Gêmeas Silenciosas, contada por Wallace (1988), as quais viveram de forma tão simbiótica, que, mesmo estando separadas temiam que o pensamento de uma pudesse atingir e causar algum mal à outra. Sentiam-se unidas e mutuamente cúmplices, entretanto chegavam a desejar a morte da outra como se, só assim, pudessem viver de maneira mais saudável.

Lewin (1994) ressaltou que a identificação primária do bebê gêmeo pode não ser com a mãe e sim com o co-gêmeo, entretanto neste caso as identificações projetivas e introjetivas entre os dois organizam poderosas forças impenetráveis, criando uma confusão de identidades que não é totalmente resolvida neste processo pelo fato de nenhum dos gêmeos ter capacidade para isso. Como resultado, pode-se criar um estado entrelaçado de desenvolvimento aprisionado, onde o relacionamento depende de identificações projetivas e introjetivas com o co- 
gêmeo, baseado no splitting. Há, então, uma ausência de limite e integridade de ego individual, estando a "pele" psíquica ${ }^{4}$ ao redor do par mais do que do indivíduo.

Lewin afirmou ainda que este sistema narcisista self-contido (selfcontided) é caracterizado pelo sentimento de inseparabilidade e incompletude individual e de um receio de sentir-se incapaz de sobreviver sozinho. Cada bebê considera o outro como parte de si mesmo, não um objeto ou pessoa separada, e usa o outro para manter o split off, projetando partes do self que são indesejadas ou também dolorosas para serem experienciadas, enquanto ao mesmo tempo funciona como um receptáculo das projeções do outro gêmeo.

Ao estudar os textos supramencionados, fiquei a pensar que muitas vezes os autores mencionaram a possibilidade das relações objetais se estabelecerem de forma diferente em gêmeos e em singulares, de tal forma que a triangulação edípica em determinados momentos envolvesse os co-gêmeos e a mãe em vez de um dos filhos com o casal parental. Assim, senti necessidade de pesquisar alguns aspectos das relações fraternas do ponto de vista de Freud e Klein, visando melhor compreender o que se passa entre singulares e fazer um paralelo com o universo dos gêmeos.

\footnotetext{
${ }^{4}$ Conceito de pele psíquica proposto inicialmente por Bick (1991).
} 


\subsection{RELAÇÕES OBJETAIS FRATERNAS}

Ao estudar o complexo de Édipo na obra de Freud, percebi existirem vários momentos em que o autor fala sobre a possibilidade de as relações objetais serem estabelecidas entre o indivíduo e um ou mais irmãos, substituindo, assim, um dos genitores na triangulação edípica.

O fenômeno chama a atenção principalmente ao se estudarem as questões da gemelaridade, em que os co-gêmeos já nascem juntos, uma vez que compartilham o útero materno durante a gestação e, ao longo dos primeiros meses de vida, costumam dividir entre si a atenção e cuidados maternos. Dessa forma, as relações objetais fraternas poderiam, talvez, serem exacerbadas em gêmeos.

Visando ter uma idéia de como Freud percebia o relacionamento fraterno, vamos fazer um passeio pela sua obra.

Freud comentou que crianças de até dois a três anos ao receberem a notícia da chegada de um novo irmão, pedem que ele seja devolvido. Chegou a dizer que:

Sou seriamente de opinião que uma criança é capaz de fazer uma estimativa justa dos contratempos que terá de esperar nas mãos do pequeno estranho. [...] As crianças nessa época da vida são capazes de ciúmes com diversos graus de intensidade e evidência. Do mesmo modo, na eventualidade de a irmãzinha de fato desaparecer após algum tempo, a criança mais velha verá toda a afeição da casa novamente concentrada nela. (FREUD, 1900a/1974, p.248-249)

No mesmo texto, afirmou que "Os sentimentos hostis para com os irmãos e irmãs devem ser muito mais freqüentes na infância do que é capaz de perceber o olhar distraído do observador adulto" (FREUD, 1900a, p. 249). 
A seguir, alegou ter perdido a oportunidade de observar como seus próprios filhos reagiram à chegada de cada novo bebê à prole, entretanto pode vivenciar algumas situações com os seus sobrinhos, dentre eles um garoto que ganhou uma irmãzinha aos 15 meses. A princípio era carinhoso com ela, mas antes de completar dois anos, reclamava do bebê e falava para os adultos sobre os seus defeitos, como por exemplo o fato de não ter dentes.

Mais tarde, Freud ressaltou o desejo de morte dos irmãos como forma de eliminar o possível rival. Na época em que esse texto foi redigido, o autor ainda não possuía uma idéia clara do fenômeno edípico, mas fazia um paralelo entre os desejos fratricidas, patricidas e matricidas. Por ocasião do falecimento de seu pai, em 1897, portanto três anos antes da "Interpretação dos sonhos", Freud descobriu o Édipo através da interpretação de um sonho seu com o falecido pai. A frase abaixo, colocada pelo autor na forma interrogativa, enfatiza a importância do Édipo sobre a rivalidade fraterna.

\begin{abstract}
Assim, quando uma criança tem motivos para desejar a ausência de outra, nada há que a impeça de dar a seu desejo a forma da morte da outra criança. [...] Mas, se os desejos de morte de uma criança contra seus irmãos e irmãs são explicados pelo egoísmo infantil que a faz considerá-los seus rivais, como iremos explicar seus desejos de morte contra seus pais, que a cercam de amor e suprem suas necessidades, e cuja preservação esse mesmo egoísmo deveria levá-la a desejar? (FREUD, 1900a/1974, p. 252)
\end{abstract}

Durante o relato da análise do pequeno Hans, Freud (1909a/1974, p. 31) mencionou a maneira como o garoto observava e verbalizava o que percebia nos genitais da irmãzinha, enquanto Ihe davam banho: o garoto ria dizendo que o pipi dela era bonito. Contudo, Freud considerou sua resposta falsa.

Num texto anterior, Freud discorrera sobre as suas primeiras hipóteses a respeito da triangulação edípica, entretanto foi entrelaçando as relações 
filiais (mãe-filho, pai-filho) com as relações fraternas: "Por conseguinte, o pai se transforma num rival perturbador para o menino, e a mãe, para a menina; e já demonstrei, no caso dos irmãos e irmãs, com que facilidade esses sentimentos podem levar a um desejo de morte" (FREUD, 1900a/1974, p. 253-254).

Ao falar dos sonhos que noticiam o desejo de morte de irmãos, é possível fazer conjecturas a respeito da forma como os irmãos gêmeos se relacionam desde o início das suas vidas, uma vez que o irmão rival estaria presente desde o útero materno.

Freud ressaltou a importância das relações entre pais e filhos na formação das psiconeuroses e logicamente na estruturação da mente, penso eu. Assim, é preciso considerar o efeito dos relacionamentos pais-gêmeos na vida de cada co-gêmeo em particular.

Ao descrever novamente a peça Oedipus Rex, que culminou com "Estarrecido ante o ato abominável que inadvertidamente perpetrara, Édipo cega a si próprio e abandona o lar. A predição do oráculo fora cumprida" (FREUD, 1900a/1974 p. 257), Freud ressaltou que a tragédia encanta a platéia porque poderia ser a representação da maldição que recai sobre todos nós, levando, talvez, a dirigir nosso primeiro impulso sexual para a mãe e o primeiro ódio e desejo assassino para o pai.

Freud mencionou diversos sonhos em que as fantasias edipianas se manifestavam através de temas relacionados à vida pré e peri-natal (fantasias intra-uterinas e durante o nascimento). Isso me leva a pensar desde quando a presença do co-gêmeo poderia fomentar emoções e fantasias diferentes entre os gêmeos e os singulares. Em nota de rodapé, Freud afirmou que "Não foi senão depois de muito tempo que aprendi a apreciar a importância das fantasias e 
pensamentos inconscientes sobre a vida do ventre" (FREUD, 1900b/1974, p. 376). Não pretendo fazer um estudo a respeito de questões pré-natais, mas apenas ressaltar a presença de dois bebês na mente e no ventre da mãe desde o período gestacional, fato que implica haver uma relação a três desde o início da vida dos gêmeos, mesmo que na mente da mãe se estabeleça uma relação dual, colocando os gêmeos no mesmo lócus afetivo.

Freud não se cansou de mencionar sonhos e relatos de pacientes em que as situações vivenciadas com os respectivos irmãos logo eram seguidas de associações referentes ao fenômeno edípico relativo às figuras parentais, tais como a história de um paciente que costumava agredir o irmão, a ponto de a mãe achar que pudesse até matá-lo. Um belo dia os pais chegaram em casa e foram deitar quando o paciente fingia estar dormindo, ao ouvir os sons ofegantes vindos do quarto dos pais, chegando a visualizar a posição do casal, fez uma analogia entre a relação do casal com a sua violenta relação fraterna: "Classificara o que havia acontecido entre seus pais sob o conceito de violência e luta e encontrara provas em favor dessa concepção no fato de ter freqüentemente observado sangue na cama da mãe" (FREUD, 1900b/1974, p. 531).

Segundo Freud (1905/1974), as crianças costumam buscar o prazer através da auto-estimulação corporal, havendo três fases da masturbação infantil: período de lactância, por volta dos quatro anos de vida e na puberdade. Ressaltou que a criança poderia ser estimulada sexualmente até por outras crianças, sendo atraídas pela curiosidade em visualizar o corpo delas.

As crianças pequenas cuja atenção foi atraída, em algum momento, para sua própria genitália - geralmente pela masturbação costumam dar o passo adicional sem ajuda externa e desenvolver um vivo interesse pelos genitais de seus coleguinhas. (FREUD, 1905/1974, p. 179-180) 
Tais situações poderiam ser mais freqüentes e precoces entre os gêmeos, que, ao vivenciarem momentos em que assistem à higienização do cogêmeo, poderiam ficar mais atraídos pela visão do corpo do irmão do que pelo dos próprios pais. Poderia, então, haver uma evolução diferente nas relações objetais em gêmeos e singulares.

No caso dos gêmeos, é possível que desde o início da vida os bebês vivenciem situações diárias onde o co-gêmeo é despido para que a higienização seja feita. Assim, a freqüência com que visualizam o corpo do outro bebê deve ser bem maior do que os bebês singulares o fazem.

Se for verdadeira a afirmação de Freud (1900a/1974) de que as crianças de certa forma se tornam "voyers" - espectadores da micção e defecação das outras, é possível que entre os co-gêmeos tais vivências sejam mais precoces e interfiram nas relações objetais fraternas.

Freud (1900a/1974, p. 209-211) enfatizou a importância dos cuidados maternos dirigidos ao bebê como uma forma de ensinar o filho a amar. Assim, é preciso valorizar a forma como o bebê é cuidado por sua mãe e também questionar se haveria alguma diferença na maneira que cada mãe cuida do filho singular e dos filhos gêmeos.

O próprio autor nos lembrou que dependendo da maneira como a mãe e também o pai lidam com o bebê, privando-o da manifestação de ternura e carícias ou excedendo nela, os pais poderiam contribuir de forma patogênica para o desenvolvimento dos filhos.

Sendo assim, que tipo de conseqüência poderia haver para cada co-gêmeo quando, ao receber esses cuidados de sua mãe, ouve o choro de seu co- 
gêmeo? Em outros momentos esses rituais de cuidados são interrompidos em função das necessidades do co-gêmeo consideradas mais urgentes pela mãe?

Os momentos em que a mãe se ocupa do co-gêmeo poderiam contribuir para criar ou aumentar a angústia de cada gêmeo? Ou por outro lado, o gêmeo poderia apresentar uma maturidade precoce?

Se tais hipóteses forem verdadeiras, poder-se-ia afirmar que as relações objetais entre mãe e gêmeos envolveriam situações triangulares quando a mãe estivesse realizando cuidados de maternagem a um bebê na presença do cogêmeo? Além disso, essas relações intra-par de gêmeos poderiam ser consideradas como incestuosas?

Freud fala sobre a barreira do incesto como algo que protege as crianças, ao fazerem suas escolhas objetais. Entretanto, na fantasia, ocorrem manifestações do impulso sexual dirigido aos pais, tanto na infância quanto na adolescência e vida adulta.

Os pais, influenciados pelos tabus culturais e, também por sua própria maturidade já conquistada, conseguem ser dóceis e atenciosos ao cuidar dos filhos, embora mantendo a devida barreira contra o incesto. Entretanto, os gêmeos, que tem a mesma idade que os respectivos co-gêmeos, poderão usar ou ser usados como objetos sexuais de seus pares, sem que as barreiras naturais (asco, vergonha e preceitos morais) estejam funcionando de forma satisfatória. Assim, é possível que a escolha objetal entre gêmeos seja fraterna e, logo, incestuosa. "Quanto mais perto se chega das perturbações mais profundas do desenvolvimento psicossexual, mais se destaca, de maneira inequívoca, a importância da escolha objetal incestuosa" (FREUD, 1905/1974, p. 214). 
Embora enfatizasse as relações objetais precoces como origem e causa dos relacionamentos futuros, também ressaltou que a adesividade ou fixabilidade dessas impressões dependem de fatores conhecidos e nem sempre chegam a desencadear sintomas repetitivos nas pessoas. Logo, não se pode dizer que a relação causa-efeito esteja completamente desvendada.

Imagine-se então o que dizer das hipóteses aqui mencionadas sobre as relações objetais entre os gêmeos e sua mãe terem características diferentes das demais duplas "mãe-bebê", considerando principalmente as relações triádicas envolvendo os co-gêmeos e a mãe, as quais poderiam estar sendo vivenciadas de forma mais intensa e precoce do que aquelas descritas nas situações edípicas propriamente ditas envolvendo os pais e cada um dos bebês.

Em relação à possibilidade da triangulação edípica ocorrer entre um dos genitores e o par de irmãos, encontrei a seguinte afirmação de Freud em relação ao caso do pequeno Hans: "Na análise ele deu uma expressão indisfarçada do seu desejo de morte contra sua irmã, e não se contentou com alusões que precisavam ser suplementadas por seu pai” (FREUD, 1909a/1974, p.121). Na seqüência desse texto, o autor ressaltou que Hans "tratava ambas as pessoas da mesma maneira, porque ambas afastavam sua mamãe dele, e interferiam em seu estar só com ela".

As considerações do autor, especialmente em relação aos "sentimentos nascidos destas relações entre pais e filhos e entre um irmão e outros, não são somente de natureza positiva, de ternura, mas também negativos, de hostilidade" (Freud 1909c/1974, p. 44), enfatizando que as relações entre o bebê e seus pais ou entre o bebê e os irmãos envolvem não apenas afetos e sentimentos positivos de ternura mas também negativos, de hostilidade, abrem um espaço para 
o estudo das relações objetais envolvendo o bebê e os irmãos em vez de nos determos apenas nas relações objetais com os genitores. Isso leva a pensar na imensidão de afetos cruzados existentes nas relações envolvendo cada co-gêmeo e seus pais.

Segundo Freud, a escolha de objeto normal implica ter a relação com a mãe funcionando como protótipo das demais. "A comparação com a maneira em que é formado2 o crânio de um recém-nascido vem logo à mente neste ponto: depois de um parto prolongado ele toma sempre a forma do molde da parte estreita da pelve materna". (FREUD 1910 /1974, p.152)

Entretanto, se a criança pode estabelecer relações objetais primitivas com as pessoas que lidam com ela no início da vida, além de seus pais, fica a questão no ar: o co-gêmeo poderia ser incluído nesse rol de relações objetais precoces?

Alguém poderia argumentar que o co-gêmeo não "cuida" do irmão gêmeo, entretanto a presença do co-gêmeo é intensa e poderia até ser percebida como "onipresença". Tal fato, de certa forma, poderia antecipar as vivências triangulares ou, melhor dizendo, a percepção das relações triádicas e a sensação de ser o terceiro excluído.

A relação mãe-bebê em gêmeos está sempre permeada pela presença do co-gêmeo. Se a afirmativa for pertinente, pode-se dizer que dificilmente a mãe estaria completamente disponível para cada bebê, numa relação dual. Se assim for, o bebê gêmeo "saberia" da onipresença e ameaça constante da perda da atenção materna. Esse poderia ser considerado um protótipo das relações futuras em gêmeos? Quais seriam as implicações disso? 
Segundo Freud (1912/1974, p. 163), a maioria das pessoas busca auxílio psicanalítico em função de "impotência psíquica", a qual implica a dificuldade de realizar o ato sexual, embora haja integridade física dos órgãos envolvidos. Ao tentar explicar a etiologia desses sintomas, o autor mencionava duas correntes necessárias para que o comportamento se manifestasse de forma normal: a corrente afetiva e a corrente sensual, sendo aquela, considerada como a mais antiga das duas.

O autor ressalta os componentes eróticos dessas interações, entretanto o fato de separar em corrente afetiva e sensual parece relevante para se estudar a questão da escolha primária de objeto, da criança.

A satisfação das necessidades biológicas pelos cuidadores, leva a criança pequena a perceber a afeição deles por ela e, certamente, vão influenciar a sua vida futura tanto nos aspectos afetivos quanto nos sexuais.

Ao longo desse mesmo texto, Freud falou sobre as frustrações que as crianças sofrem por não poder realizar suas fantasias amorosas com as figuras parentais em função da barreira do incesto. Considerado como sendo um tabu, presente praticamente em todas as culturas, há que se questionar a partir de quando essa proibição funciona como tal na mente das crianças e especialmente dos bebês. É possível que, ao invés de tabu ser algo inato, o tabu seja um aspecto herdado culturalmente. Se assim for, a mãe, o pai e os demais cuidadores acabam provocando a barreira e impedindo que os comportamentos incestuosos se manifestem. Entretanto, nas relações fraternas entre crianças em idades precoces, a barreira do tabu do incesto ainda não está vigente e, logo, as fantasias e até actings são comuns.

É possível que entre os co-gêmeos tais fenômenos aconteçam de 
forma mais freqüente do que nos demais irmãos, pelo fato de ambos terem a mesma idade e, logo, um desenvolvimento emocional cronologicamente semelhante. Diferente dos irmãos singulares em que, via de regra, haveria pelo menos um intervalo de nove meses entre as idades. Tal diferença se torna mais significativa ao se considerar que, ao longo desse tempo, o irmão mais velho vivenciou inúmeras situações nos quais os cuidadores investiram não só nos cuidados para a preservação de sua vida, mas também o "instruíram" sobre os vários aspectos da inibição de atos libidinosos tanto auto quanto hetero-eróticos. Assim, podendo haver uma diferença significativa nas relações objetais vivenciadas pelos bebês singulares e bebês gêmeos.

Até que ponto os cuidadores conseguiriam proibir as relações afetivas e as fantasias sensuais intra-par de gêmeos? "Os instintos do amor são difíceis de educar; sua educação ora consegue de mais, ora de menos" (FREUD 1912/1974, p. 172). Poderia a "onipresença" do co-gêmeo favorecer a triangulação edípica envolvendo os gêmeos e uma outra pessoa, em vez do triângulo: mãe, pai e filho?

Considerando o fato de os gêmeos muitas vezes presenciarem os rituais de higiene feitos pela mãe (ou cuidador substituto) no co-gêmeo, é possível questionar se a visão dos genitais do irmão iria contribuir para a escolha objetal futura. Entretanto, é preciso lembrar que, no mesmo texto, o autor abordou a evolução do desenvolvimento da sexualidade, ressaltando que os resquícios da homossexualidade seriam utilizados na sublimação, contribuindo "como um fator erótico para a amizade e a camaradagem, para o espirit de corps e o amor à humanidade em geral" (1911/1974, p. 84).

No texto Totem e Tabu, Freud nos fala sobre o temor ao incesto 
entre os povos totêmicos. O assunto é considerado sob diversos aspectos, enfatizando que o incesto nem sempre se refere apenas aos laços consangüíneos, mas também aos laços totêmicos. Isso significa que mesmo não sendo parentes, se pertencerem ao mesmo clã, não poderão se relacionar sexualmente: "a proibição de relações sexuais entre os membros do mesmo clã, parece ter constituído o meio apropriado para impedir o incesto grupal; dessa maneira, estabeleceu-se e persistiu muito tempo após a sua raison d'être haver cessado" (FREUD, 1913/1974, p. 27).

Essa forma de considerar a evitação dos relacionamentos intragrupos totêmicos parecia ter a função de afastar a possibilidade de acontecer o incesto a qualquer preço. Assim, haveria costumes específicos com o intuito de promover as chamadas "evitações" (FREUD, 1913/1974, p. 29), tais como entre pai e filha, irmão e irmã, sogra e genro.

Essas passagens do texto dão idéia do temor ao incesto entre irmãos, que me leva a pensar no quanto esses povos primitivos temiam essa relação fraterna. Vale lembrar que estes consideravam o nascimento de filhos defeituosos como castigo dos deuses, uma vez que desconheciam os riscos da gestação em casais com laços consangüíneos muito próximos. Isso sugere que, se os irmãos singulares podem sentir tanta atração a ponto da proximidade ser evitada a qualquer custo, como seriam as relações intra-par de gêmeos?

Freud enfatiza, no mesmo texto, a fantasia incestuosa entre irmãos: "A psicanálise nos ensinou que a primeira escolha de objetos para amar feita por um menino é incestuosa e que esses são objetos proibidos: a mãe e a irmã" (FREUD 1913/1974, p. 37).

Fato este que leva novamente a pensar que a triangulação edípica em gêmeos poderia, a priori, envolver os co-gêmeos e sua mãe. Isto porque o par é 
mantido junto no útero e, na fantasia, é possível que haja a onipresença do cogêmeo, sendo a mãe (ou seu substituto) o terceiro vértice do triângulo.

Freud recorda que a manifestação das pulsões sexuais no início da vida não são dirigidas a qualquer objeto externo.

Os componentes instintivos separados da sexualidade atuam independentemente uns dos outros, a fim de obter prazer e encontrar satisfação no próprio corpo do sujeito. Essa fase é conhecida como a do auto-erotismo, sendo sucedida por outra, na qual um objeto é escolhido. (FREUD, 1913/1974, p.111)

O autor continuou, dizendo que, entre as duas fases - auto-erotismo e busca do objeto, existiria uma intermediária onde haveria a busca de um objeto interno. Neste momento, é possível lembrarmo-nos dos "toques físicos" que o bebê realiza no corpo do co-gêmeo questionando se seriam atividades auto-eróticas ou se já estaria havendo uma relação objetal com o irmão.

Nessas alturas da construção deste trabalho, fico a questionar se entre os co-gêmeos poderia haver situações onde o encontro do objeto seria mais precoce, uma vez que, desde os primeiros dias de vida, haveria a presença constante de "um outro" que interfere com toques físicos na pele do co-gêmeo, nas várias situações onde são colocados lado a lado (colo, berço, carrinho de bebê).

Penso que entre os irmãos gêmeos é possível que as catexias de objeto poderiam transitar do próprio ego para o objeto externo, no caso, o cogêmeo, de forma intensa e com características diferentes das relações vivenciadas pelos bebês singulares. Essa hipótese necessitaria ser investigada, por exemplo, por meio da observação das relações intra-par de gêmeos. Isto porque poderia haver uma identificação exacerbada entre cada gêmeo e seu respectivo co-gêmeo. Logo haveria aí uma relação "pseudo-narcísica", ou seja, o gêmeo poderia estar se 
relacionando com o co-gêmeo como se fosse um duplo de si mesmo.

Isso também parece relevante para se pensar que, nas relações objetais entre os co-gêmeos, os vínculos afetivos poderiam ser mais precoces e mais intensos do que em bebês singulares.

Percebe-se que Freud mencionou que os sentimentos hostis relacionados ao pai poderiam ser deslocados para um substituto daquele. Se considerarmos o pai como a figura que provoca o distanciamento entre a mãe e o bebê, não poderia ser o co-gêmeo considerado como o substituto do pai e/ou o terceiro vértice do triângulo edípico, ao qual o sujeito dirigiria sua hostilidade?

A criança se alivia do conflito que surge dessa atitude emocional de duplo aspecto, ambivalente, para com o pai deslocando seus sentimentos hostis e temerosos para um substituto daquele. $O$ deslocamento, no entanto, não pode dar cabo do conflito, não pode efetuar uma nítida separação entre os sentimentos afetuosos e os hostis. Pelo contrário, o conflito é retomado em relação ao objeto para o qual foi feito o deslocamento: a ambivalência é estendida a ele. (FREUD, 1913/1974, p. 156-157)

No texto Totem e Tabu, Freud falou sobre o totem como sendo o representante do pai primevo que teria sido assassinado pelos filhos. Ressaltou que, na ausência do pai, poderiam eclodir sentimentos de competição e agressividade entre os irmãos, levando à possibilidade de fratricídio. "A horda patriarcal foi substituída, em primeira instância, pela horda fraterna, cuja existência era assegurada pelo laço consangüíneo" (1913/1974, p. 174)

Pensando sobre tais fenômenos, é possível conjecturar que, entre os co-gêmeos, devem existir sentimentos intensos onde ocorre a disputa pela atenção e/ou posse da figura materna e isso envolva relações fraternas e não apenas paternas. Logo, o desejo de fratricídio poderia substituir o de parricídio ou matricídio nas relações triangulares vivenciadas pelos gêmeos desde o início da 
vida.

Ao fazer um paralelo entre o totemismo e a religião cristã, Freud alegou que Cristo foi o primeiro a utilizar um método para mitigar a culpa, assim, "Sacrificou a própria vida e assim redimiu do pecado original o conjunto de irmãos. A doutrina do pecado original era de origem órfica" (FREUD, 1913/1974, p. 182)

Tais reflexões novamente me levam a hipotetizar a possibilidade de cada co-gêmeo desejar ocupar o lugar de privilegiado - pai - na relação com a mãe; entretanto, por outro lado, o privilegiado pode estar sendo considerado o próprio co-gêmeo, levando a manifestações de ciúmes e desejos fratricidas relativos ao co-gêmeo, o qual "saberia" que, ao receber as atenções e cuidados maternos estaria também sendo vítima de tais desejos por parte do co-gêmeo, agora vivenciando a sensação de ser o terceiro excluído.

Um outro aspecto que chamou a minha atenção foi a referência, feita por Freud, às tragédias gregas, lembrando que inicialmente haveria apenas um ator, personificando o Herói e o coro. Mais tarde foram incluídos mais dois atores que representavam aspectos característicos do Herói, o qual deveria sofrer, conduzindo a "culpa" da tragédia, cujo fundamento era difícil de ser descoberto. O autor continua sua análise questionando porque o herói deveria sofrer tanto e concluiu que: "Na realidade remota, haviam sido verdadeiramente os membros do Coro que tinham causado o sofrimento do Herói; agora, entretanto, desmanchavamse em comiseração e lamentações e era o próprio Herói o responsável por seus próprios sofrimentos" (FREUD, 1913/1974, 185). Na verdade, Freud explicou que o herói representava o pai e o Coro eram os irmãos, logo o pai, Herói acabava por redimir o crime que fora praticado pelos irmãos.

Freud (1913/1974, p. 185) continuou sua reflexão dizendo que o 
resultado dos fenômenos, por ele aqui mencionados, demonstra que "os começos da religião, da moral, da sociedade e da arte convergem para o complexo de Édipo."

Freud nos lembrou que: "O que jaz por trás do sentimento de culpa dos neuróticos são sempre realidades psíquicas, nunca realidades concretas. O que caracteriza os neuróticos é preferirem a realidade psíquica à concreta ..." (FREUD, 1913/1974, p. 188-189)

Fundamentado nessa conviç̧ão comentou a possibilidade do parricídio nas comunidades totêmicas ter ocorrido apenas na fantasia e não na realidade, mas, mesmo assim, teria levado ao aparecimento do clã fraterno em substituição à horda patriarcal.

Assim, fico a pensar se entre os co-gêmeos a relação fraterna poderia ser vivenciada de forma tão intensa a ponto de ser priorizada em detrimento dos vínculos mãe-filho, pai-filho e nas respectivas triangulações pais-filhos.

Freud dizia que as escolhas objetais se fundamentam nas relações com o objeto primevo, entretanto percebeu que a busca de prazer derivava das experiências auto-eróticas vivenciadas em funções vitais ligadas à auto preservação. Logo, esses primeiros objetos de amor são as pessoas que cuidam e protegem as crianças. Esse tipo e fonte de escolha objetal é nominado como anaclítico ou de ligação. Entretanto:

Descobrimos, de modo especialmente claro, em pessoas cujo desenvolvimento libidinal sofreu alguma perturbação, tais como pervertidos e homossexuais, que em sua escolha ulterior dos objetos amorosos elas adotaram como modelo não sua mãe mas seus próprios eus. Procuram inequivocamente a si mesmas como um objeto amoroso, e exibem um tipo de escolha objetal que deve ser denominado 'narcisista'. Nessa observação, temos o mais forte dos motivos que nos levaram a adotar a hipótese do narcisismo. 
(FREUD, 1914/1974, p.103-104)

Segundo Freud, a forma de amar pode ser de dois tipos: (1) narcisista [(a) o que ela própria é (isto é, ela mesma), (b) o que ela própria foi, (c) o que ela própria gostaria de ser, (d) alguém que foi uma vez parte dela mesma]; (2) anaclítico ou de ligação [(a) a mulher que a alimenta, (b) o homem que a protege, e a sucessão de substitutos que tomam o seu lugar. A inclusão do caso (c) do primeiro tipo não pode ser justificada até uma etapa posterior deste exame] (FREUD 1914/1974, p.107).

Será possível que, em algum momento, os gêmeos possam se sentir fusionados aos co-gêmeos? Se assim for, a "escolha objetal gemelar" poderá ser do tipo narcisista descrito no item "d"?

Neste momento passo a questionar: haveria entre gêmeos uma terceira possibilidade de escolha objetal, na qual o co-gêmeo poderia ser considerado como uma extensão de si mesmo, sendo ao mesmo tempo "um outro" e um "si mesmo"?

Athanassiou (1986) mencionou os estudos de Mahler (1952) que utilizava o termo simbiose para descrever os estágios iniciais do desenvolvimento infantil durante o qual a identificação do bebê se funde à de sua mãe, até por volta de seis a oito meses. Afirmou também que alguns autores (LEONARD, 1961 e DIBBLE; COHEN, 1981, apud ATHANASSIOU) acreditam que, para os gêmeos, o primeiro objeto não é a mãe e sim o co-gêmeo e consideram essa idéia fundamental para justificar a importância da chamada fase simbiótica em gêmeos. Segundo a autora, essa fase é intensamente transferida ao relacionamento intra cogêmeos, antes de vivê-la com o objeto maternal. 
Athanassiou cita os trabalhos de Burlinghan (1952) e Zazzo (1960) nos quais os gêmeos muitas vezes confundiam sua imagem com a do co-gêmeo no espelho. Lézine (1951) relatou situação análoga, na qual a criança, solicitada a mostrar parte de seu corpo, apontava para a do co-gêmeo.

Athanassiou recorreu ao conceito de identificação adesiva (BICK, 1991) para explicar que, inicialmente, os gêmeos se sentem como se cada um fosse a pele psíquica do outro, que estaria ou não unida à pele materna. Segundo a autora, quando esta fusão é atacada dá-se origem a um sentimento dilacerante! A simbiose gemelar assim descrita representa uma manifestação da identificação projetiva maciça existente intra-par de co-gêmeos. Athanassiou mencionou novamente os estudos de Burlinghan ressaltando haver então um ponto de interpenetração que é transformada em intrusão mútua. Em tais situações, nem sempre a mãe possui capacidade suficiente de revêrie para acolher as angústias dos bebês, pensá-las e decodificá-las a ponto de tranqüilizar os gêmeos!

Athanassiou enfatizou que, nessas circunstâncias, não há duas, mas sim três pessoas presentes desde o início, sendo que a mãe contribui de forma intensa para o impacto que as rivalidades terão no desenvolvimento dos gêmeos.

Freud observou que o nascimento de um irmão não costuma ser recebido de bom grado pelas crianças pequenas, principalmente entre os dois e os cinco anos, enfatizando que "Se a diferença de idade é menor, na época em que a atividade mental da criança se aviva em determinado grau de intensidade, ela já encontra aí seu competidor e a ele se adapta" (FREUD, 1916/1974, p. 245). Ressaltou ainda a possibilidade de haver uma atitude cordial encobrindo aquela mais hostil que Ihe parecia ser a mais verdadeira.

O estudioso afirmou também que a criança pequena muitas vezes 
não ama os irmãos; na verdade odeia-os como seus rivais "e é fato sabido que esta atitude freqüentemente persiste por muitos anos, até ser atingida a maturidade ou mesmo até mais tarde, sem interrupção" (FREUD, 1916/1974, p. 245).

Por outro lado, se houver uma diferença de idade maior, o bebê poderá ser mais bem recebido, despertando alguma simpatia por ser um objeto interessante, tal qual uma boneca viva, principalmente nas meninas, que podem manifestar atitudes maternais para com o novo irmão. "Contudo, falando honestamente, se alguém encontrar, em sonho, um desejo de morte contra um seu irmão ou irmã, raramente há que considerá-lo um enigma e, sem dificuldades, pode situar seu protótipo no início da infância [...]" (FREUD, 1916/1974, p. 245-246).

Freud continuou sua narrativa falando que entre irmãos a competição é um fenômeno comum: "Provavelmente não há quarto de crianças sem violentos conflitos entre seus ocupantes. Os motivos de tais desavenças são a rivalidade pelo amor dos pais, pelas posses comuns, pelo espaço vital" (FREUD, 1916/1974, p. 245-246). Ressaltou ainda que as relações nas quais o ódio está presente entre os irmãos são mais aceitas do que entre pais ou mães com os respectivos filhos. "Poderíamos, quando muito, achar compreensíveis o ódio e a competição entre irmãos e irmãs. Mas como podemos supor que sentimentos de ódio venham a surgir nas relações entre filha e mãe, entre pais e filhos?" (FREUD, 1916/1974, p. 246).

Em todos os trechos acima mencionados, Freud enfatizava a competição existente entre irmãos, especialmente nos primeiros anos de vida (2 a 5 anos). Entretanto, caso tivesse observado bebês gêmeos, poderia ter detectado tais fenômenos em época mais precoce, uma vez que são comuns as agressões entre os co-gêmeos a partir do quarto trimestre de vida, quando os bebês começam a se 
locomover/andar, provavelmente motivados pela constante companhia/rival que leva a mordida, pancada, empurrão e agarra brinquedos, já por volta de oito a dez meses. Pelo fato de esta agressão começar em época muito precoce, estágio préverbal, constitui um sério dilema para os pais por ser difícil ensinar o controle da agressividade ou até a substituição do ato pela verbalização em crianças tão jovens (BIALE, 1989).

No que concerne à sexualidade infantil, Freud ressaltava suas peculiaridades que poderiam ser consideradas "perversas" no indivíduo adulto. Dentre elas encontra-se a "barreira contra o incesto sexual (proibição contra a busca da satisfação sexual em relações consangüíneas próximas)" (FREUD, 1916/1974, p. 250). Esta e outras barreiras não são inatas e se organizam a partir do desenvolvimento e da educação.

$\mathrm{O}$ autor prossegue explicando que as crianças vivenciam e manifestam desejos sexuais pelas pessoas mais próximas, os quais, se percebidos, são reprovados pelos adultos cuidadores. "Entre esses desejos proibidos, merecem especial ênfase os desejos incestuosos - isto é, aqueles que objetivam a relação sexual com pais, irmãos e irmãs" (FREUD, 1916/1974, p. 251-252).

Embora esses desejos incestuosos sejam tão criticados e evitados pelos diversos povos, a psicanálise verificou que: "escolha incestuosa de um objeto de amor é, pelo contrário, a primeira e a invariável escolha, e senão mais tarde é que a resistência contra ela se manifesta; sem dúvida, não é impossível descobrir a origem desta resistência na psicologia individual" (FREUD, 1916/1974, p. 251-252).

Se isto for verdadeiro, o que se pode pensar a respeito das relações gemelares nos primeiros anos de vida? Considerando que, em irmãos singulares, o cuidado da mãe (ou substituta) se volta para o um bebê de cada vez - as práticas 
educativas impeditivas ao incesto poderiam ser mais efetivas do que nos gêmeos?

É provável que, quando o irmão mais novo busca uma relação afetiva mais íntima com o irmão mais velho, este já deveria ter estabelecido alguma barreira contra $o$ incesto, impedindo que o pequeno avançasse em seu intento. Entretanto, os gêmeos, que possuem a mesma idade, poderiam vivenciar relações incestuosas intra-par com mais facilidade, uma vez que em ambos as barreiras contra o incesto não estariam ainda minimamente erigidas.

Freud abordou as relações fraternas de forma bastante interessante, chegando a afirmar que: "Quando outras crianças aparecem em cena, o complexo de Édipo avoluma-se em um complexo de família" (FREUD, 1917, p. 389-390). As manifestações emocionais são muito mais sinceras, freqüentes e intensas quando partem das crianças. De tal forma que se houver a morte de um irmão, por exemplo, é possível detectar, por meio da análise, o quanto esse fato foi importante para a criança, mesmo que aparentemente não tenha ficado em sua memória. Por outro lado, ressaltou que o aparecimento de um novo irmão pode favorecer a eclosão de conflitos fraternos. À medida que os irmãos crescem, podem surgir relações objetais de diferentes coloridos, tais como:

Pode tomar sua irmã como objeto de amor, à maneira de substituta da mãe infiel. Onde há diversos irmãos, todos cortejando uma irmã mais nova, surgem, já na época infantil, situações de rivalidade hostil que são tão importantes, na vida, mais tarde. Uma menina pode encontrar em seu irmão, mais velho, um substituto para seu pai, que não mantém mais um interesse afetuoso por ela como o fazia em anos anteriores. Ou pode tomar uma irmã mais nova como substituta da criança que ela, em vão, desejou ter de seu pai. (FREUD, 1917/1974, p. 389-390)

Isto me levou (novamente) a refletir sobre a maneira como o complexo de Édipo ocorre nos gêmeos, considerando a quase constante presença 
do co-gêmeo. Poderiam os gêmeos sentir-se como se fossem um casal? Poderia a mãe ser considerada a rival, ao invés do objeto de amor? Como se dá essa triangulação: pais-gêmeo ou gêmeos-mãe ou gêmeos-pai?

Freud ressaltou que o tema do incesto já foi estudado pela ciência em vários momentos, tentando explicar a "proibição do incesto". Muito tem se falado sobre a tendência sexual entre as pessoas de sexo oposto, nos membros da própria família, em função da proximidade em que vivem desde a infância. Além disso, falase num propósito biológico que evitaria a consangüinidade, entretanto Freud acreditava não ser isso possível, pois se assim o fosse não haveria necessidade de tantos cuidados para impedir o incesto. Lembrou ainda, que entre os povos primitivos, as proibições contra o incesto eram (são) ainda mais rigorosas. "A primeira escolha objetal de um ser humano é regularmente incestuosa, dirigida, no caso do homem, à sua mãe e à sua irmã; e necessita das mais severas proibições para impedir que essa tendência infantil persistente se realize" (FREUD, 1917/1974, p. 391).

Outro fato importante mencionado é que, na mitologia, o incesto era permitido aos deuses, sendo que "na história antiga, podem constatar que o casamento incestuoso com a irmã era um preceito santificado imposto à pessoa do soberano (entre os faraós egípcios e os incas do Peru)" (FREUD,1917/1974, p. 391). Logo, o que estava em jogo era o privilégio, proibido "apenas" ao homem comum. Isto novamente me levou a pensar na hipótese de que a relação objetal entre gêmeos poderia ocorrer de forma fraternalmente incestuosa.

Ao relatar o caso do "Homem dos Lobos", Freud (1918/1974, p. 3637) falou sobre as brincadeiras sexuais entre os irmãos, ressaltando a possibilidade de a relação objetal com a irmã ser matriz de outros relacionamentos. Durante 
muito tempo, o paciente percebia a irmã como um objeto que competia com ele, em relação à busca de atenção dos pais, desejando ser considerado como alguém superior na prole. Mais tarde, demonstrava inveja pelas capacidades e realizações intelectuais da irmã, as quais o paciente acreditava serem valorizadas pelo pai. Por volta dos quatorze anos, a relação fraterna foi melhorando: "uma disposição mental semelhante e uma oposição comum aos pais aproximaram-nos tanto, que se tornaram os melhores amigos. Durante a tempestuosa excitação sexual da sua puberdade, ele se arriscou a uma tentativa de aproximação física mais íntima”. A irmã não atendeu aos seus apelos, repudiando-o, então ele se interessou/procurou por outra garota que trabalhava na residência da família e tinha o mesmo nome da irmã. Mais tarde, buscou por outras mulheres com características semelhantes, ou seja, eram "criadas, cuja educação e inteligência estavam necessariamente abaixo da sua". Ressaltou ainda que "todos esses objetos de amor eram substitutos para a figura da irmã a quem tinha que renunciar", assim "havia obtido o controle decisivo sobre a sua escolha de objeto".

Ao fazer a análise do "sonho dos lobos", vivenciado por um de seus pacientes, Freud chegou à conclusão de que se referia, entre outras coisas, ao fato de ter acordado e presenciado o coito dos pais. Enfatizou que, embora o sonho do paciente tenha ocorrido quando tinha quatro ou cinco anos de idade, deduziu que a cena deveria ter ocorrido aos dezoito meses de vida. Entretanto, chegou a questionar se haveria ocorrido aos seis meses e não com um ano e meio. $\mathrm{Na}$ seqüência, o autor faz o seguinte questionamento:

Portanto, o conteúdo da cena não pode ser, por si, um argumento contra a sua credibilidade. As dúvidas quanto à sua probabilidade poderão girar em torno de três pontos: se uma criança na tenra idade de um ano e meio poderia estar numa posição de absorver a percepção de um processo tão complicado e preservá-la tão 
acuradamente em seu inconsciente; em segundo lugar, se é possível, aos quatro anos de idade, que uma revisão transferida das impressões assim recebidas penetre no entendimento; e, finalmente, se qualquer procedimento poderia trazer para a consciência, coerente e convincentemente, os detalhes de uma cena dessa natureza, experimentada e compreendida em tais circunstâncias. (FREUD, 1918/1974, p. 55)

Isso me levou a pensar na intensidade e importância das vivências dos gêmeos durante os primeiros meses de vida e as conseqüências para a estruturação de suas personalidades.

No caso do Homem dos Lobos, Freud falava sobre a questão de o paciente ter sido seduzido pela irmã. Este fato que leva-nos a pensar na importância das relações objetais fraternas. "A hostilidade em relação às mulheres, devida à sedução pela irmã, encontrou intensa expressão nesse período. E estava destinada a perturbá-lo muitas vezes na sua vida erótica posterior" (FREUD, 1918/1974, p. 88).

No texto "Uma criança é espancada", Freud apresentou uma passagem que me pareceu importante para analisar as relações fraternas entre os co-gêmeos na disputa pela atenção e amor dos pais. Enfatizou que a questão principal não era a relação entre mãe e filha à qual a fantasia de espancamento estaria ligada e, sim, ao fato de haver outras crianças na cena com pouca diferença de idade, que estariam dividindo o amor dos pais. "A idéia de o pai batendo nessa odiosa criança é, portanto, agradável, independente de ter sido realmente visto agindo assim. Significa: 'O meu pai não ama essa criança, ama apenas a mim.'” (FREUD, 1919a/1974, p. 234)

Freud relembrou suas hipóteses levantadas no texto Totem e Tabu a respeito de como a religião e a repressão moral funcionam através de um 
processo de domínio do complexo de Édipo. Além disso, falou sobre a premência de se superar a rivalidade que permaneceu entre os irmãos, membros da geração mais nova. Isto porque, com a morte do pai, teria surgido uma competição entre os filhos para ocupar o lugar outrora ocupado por ele. "Mesmo hoje os sentimentos sociais surgem no indivíduo como uma superestrutura construída sobre impulsos de rivalidade contra seus irmãos e irmãs" (FREUD, 1923/1974, p.52).

Novamente é possível conjecturar que os gêmeos poderiam vivenciar de forma mais intensa e/ou freqüente as situações de competição e rivalidade.

No texto Uma breve história da psicanálise, o autor comentou ter se equivocado ao acreditar que a sedução real pudesse ter ocorrido em seus pacientes como precursora da neurose, colocando então a importância maior na fantasia sobre o tema. Entretanto, deixou claro que, em alguns casos, a sedução, de fato, poderia ter ocorrido.

Mesmo agora não creio que forcei as fantasias de sedução aos meus pacientes, que as 'sugeri'. Eu tinha de fato tropeçado pela primeira vez no complexo de Édipo, que depois iria assumir importância tão esmagadora, mas que eu ainda não reconhecia sob seu disfarce de fantasia. Além disso, a sedução durante a infância retinha certa parcela, embora mais humilde, na etiologia das neuroses. Mas os sedutores vieram a ser, em geral, crianças mais velhas. (FREUD, 1925/1974, p. 47-48)

Quando Freud falou, no final da citação anterior, que os sedutores poderiam ser "crianças mais velhas", fiquei a pensar se os co-gêmeos poderiam funcionar como sedutores recíprocos, já que, por serem da mesma idade, poderiam não ter os diques de "vergonha e moralidade" já instalados e que, porventura, impediriam que as crianças mais velhas agissem de forma mais incisiva com os menores. Assim, os gêmeos poderiam agir de forma mais natural e talvez até mais 
agressivamente sedutores do que as demais crianças...

Freud (1931/1974, p. 268) falou sobre o desejo insaciável do bebê pelo seio materno, ressaltando que as meninas principalmente acusam a mãe de não tê-las amamentado pelo tempo suficiente. Continuou o texto dizendo que, mesmo se os bebês fossem amamentados por dois ou três anos, como os povos primitivos, a queixa seria a mesma em função da voracidade típica das crianças.

Considerando que a mãe de gêmeos tem que dividir, de fato, a amamentação no peito bem como a atenção a cada bebê quando os alimenta de outras formas, acredito que isto poderia interferir nas relações objetais de tal forma que a triangulação edípica poderia ser, a princípio, entre a mãe e os bebês, colocando cada co-gêmeo em grau de importância maior do que a figura paterna para cada bebê. Melhor dizendo, o co-gêmeo funcionaria como aquele que provoca o afastamento da mãe, ficando o bebê na posição do terceiro excluído. Situação que se inverte quando o outro co-gêmeo está sendo cuidado pela mãe.

Ao falar sobre a chegada de um novo irmão, Freud falou sobre as frustrações do mais velho por ter perdido o leite materno, enfatizando que o abalo se repete a cada nascimento dos demais irmãos, mesmo que aquela criança continue sendo a preferida da mãe.

Contudo, o que a criança não perdoa ao indesejado intruso e rival não é apenas a amamentação, mas sim todos os outros sinais de cuidado materno. Sente que foi destronada, espoliada, prejudicada em seus direitos; nutre um ódio ciumento em relação ao novo bebê e desenvolve ressentimento contra a mãe infiel, o que muitas vezes se expressa em desagradável mudança na conduta. [...] Ademais não faz muita diferença se acontece a criança continuar sendo a preferida de sua mãe. As exigências de amor de uma criança são ilimitadas; exigem exclusividade e não toleram partilha. (FREUD, 1933b/1974, p. 151-152)

O que será que acontece entre os co-gêmeos que já nascem 
juntos? Nesse ponto fica a questão: o complexo de Édipo em gêmeos seria diferente do dos singulares?

Poder-se-ia falar em escolha objetal do co-gêmeo em substituição à relação objetal entre cada bebê e seu pai ou poderia haver apenas um comportamento imitativo entre os co-gêmeos visando receber a atenção materna em cada situação onde os três estão presentes (na realidade ou na fantasia)?

Nesse momento, convém lembrarmos de um texto onde 0 autor falou sobre a identificação, explicando que, em algumas circunstâncias, a criança poderia se identificar com figuras substitutas do pai:

Se um menino se identifica com seu pai, ele quer ser igual a seu pai; se fizer dele o objeto de sua escolha, o menino quer tê-lo, possuí-lo. No primeiro caso, seu ego modifica-se conforme o modelo de seu pai; no segundo caso, isso não é necessário. Identificação e escolha objetal são, em grande parte, independentes uma da outra; no entanto, é possível identificar-se com alguém que, por exemplo, foi tomado como objeto sexual, e modificar o ego segundo esse modelo. (FREUD, 1933a, p. 82)

Como vimos até aqui, Freud mencionou em vários momentos a possibilidade de existirem relações objetais fraternas de forma similar às relações triangulares entre a criança e seus pais. A seguir, vamos percorrer alguns textos nos quais Klein abordou o mesmo tema.

Desde os primeiros escritos publicados por Klein, a autora já expressava algumas idéias diferentes daquelas propostas por Freud, dentre elas a existência de um superego primitivo atuando ao longo do primeiro ano de vida, o qual estaria vinculado ao fenômeno edípico, que descobriu já estar ocorrendo precocemente.

Klein acreditava que "o sentimento de culpa, associado à fixação 
pré-genital já é um efeito do direto conflito edipiano" (1928/1996, p. 216). Além disso, ressaltou que o sentimento de culpa era resultado da introjeção total ou parcial dos objetos amorosos edipianos, logo o sentimento de culpa já é um produto da formação do superego. Explicou ainda porque o superego é tão severo por essa época: "Por um lado, o sentimento de culpa se prende às fases sádico-oral e sádico-anal, que ainda são as predominantes; por outro, o superego se forma quando essas fases ainda estão em ascendência, o que explica seu rigor sádico" (KLEIN, 1928/1996, p. 217)

O sentimento de culpa também é importante por estar vinculado às frustrações anais e orais, as quais formam o protótipo das demais frustrações ao longo da vida, significam também punição e dão origem à ansiedade.

Se assim for, o que se poderia pensar a respeito de tais sentimentos ocorrendo na interação "gêmeo, co-gêmeo e mãe", onde a possibilidade de se sentir como "o excluído" pela mãe e portanto frustrado é tão grande? Quando a mãe cuida do co-gêmeo, o bebê poderia se sentir frustrado e/ou punido por ela?

Klein comentou que, na fase da feminilidade, as fezes são equiparadas ao bebê que a criança espera ter. Logo, a criança deseja roubar da mãe tanto o bebê quanto as fezes dela. Ressaltou ainda:

Aqui podemos perceber dois objetivos que se fundem um ao outro. Um é governado pelo desejo de ter filhos, e a intenção da criança é apropriá-los, o outro objetivo é motivado pelo ciúme de futuros irmãos, cujo surgimento é esperado, e pelo desejos de destruí-los dentro da mãe. (Um terceiro objeto das tendências sádico-orais do menino dentro da mãe é o pênis do pai.) (Klein, 1928/1996, p. 219).

Neste momento, é possível questionar se entre os co-gêmeos 
haveria algum desejo de se apropriar do irmão e/ou destruí-lo, no início da vida. Se assim fosse, haveria possibilidade de se perceber alguma evidência no comportamento dos bebês?

Ao longo do texto acima comentado, a autora teceu diversos comentários a respeito das relações objetais presentes na vivência do complexo de Édipo por crianças de ambos os sexos com os respectivos pais.

Klein mencionou as relações sexuais nas crianças pequenas entre irmãos ou amiguinhos, as quais muitas vezes ocorrem após a observação do coito entre os pais, que motiva a excitação nas crianças: "consistem nos atos mais diversos: olhar, tocar, defecar juntos, felação, cunilíngua e muitas vezes tentativas diretas de realizar o coito" (KLEIN, 1928/1996, p. 226). A autora ressaltou que o sentimento de culpa, nestes casos, é provocado principalmente "pelo fato de que o objeto amoroso escolhido sob pressão da excitação é trazida pelo conflito edipiano, é visto pela criança como substituto do pai, da mãe ou de ambos" (p. 226). Tais considerações recordam os escritos de Freud a respeito das relações fraternas, em que a triangulação edípica acaba acontecendo com irmãos substituindo uma das figuras parentais, mencionadas anteriormente neste trabalho.

É bem possível que os gêmeos possam vivenciar as situações citadas por Klein de forma mais freqüente e até mais intensa, uma vez que estão juntos na maior parte do tempo nos primeiros anos de vida.

A autora enfatizou a seriedade dessas situações para a estruturação do psiquismo da criança, ressaltando que esse tipo de vivência formaria um ponto de fixação no desenvolvimento do superego. "Como conseqüência da necessidade de punição e da compulsão à repetição, essas experiências muitas vezes fazem com que a criança se submeta a traumas sexuais" 
(Klein, 1928/1996, p. 226).

Considerando o acima exposto, mais uma vez surge a questão de como acontecem as relações fraternas entre os co-gêmeos, de que maneira elas se constituem como substitutos das relações objetais de cada bebê com os respectivos pais e quais seriam as conseqüências para a vida futura dos gêmeos.

Klein considerou o início do complexo de Édipo acontecendo durante o primeiro ano de vida, seguindo inicialmente a mesma trajetória em ambos os sexos e tendo a relação com o seio materno como um dos fatores fundamentais para o desenvolvimento emocional e sexual. "Por isso, tomo a relação com o seio como ponto de partida para a descrição do início do complexo de Édipo em ambos os sexos" (1945/1996, p. 452).

A autora disse que a satisfação que o bebê vivencia no seio materno propicia a busca de novos objetos, especialmente o pênis paterno. Por outro lado, a frustração também vivenciada pela não presença constante do seio favorece o incremento do desejo pelo pênis paterno.

Considerando que a frustração está ligada tanto a fatores externos quanto aos internos, o que se constata é a frustração como algo inerente à vida do bebê, que deseja a gratificação ilimitada.

É inevitável que haja alguma frustração no seio, mesmo sob condições mais favoráveis, pois aquilo que o bebê realmente quer é a gratificação ilimitada. A frustração sentida no seio da mãe faz com que tanto o menino quanto a menina se afastem dele e estimula na criança o desejo de obter gratificação oral com o pênis do pai. $O$ seio e o pênis são, portanto, os objetos primários dos desejos dos bebês. (KLEIN, 1945/1996, p. 452-453)

A frustração e a gratificação vão contribuir para o estabelecimento da relação do bebê com um seio bom amado e outro que é o seio mau odiado. Tais 
atitudes conflitantes dirigidas ao seio materno são transferidas/deslocadas para a relação a ser estabelecida com o pênis do pai.

As frustrações sofridas com o seio aumentam as exigências e esperanças na nova relação de objeto. Os impulsos agressivos motivados pela frustração acabam transformando as figuras parentais em figuras feridas e ao mesmo tempo, retaliadoras na mente do bebê, as quais o ameaçam com os mesmos ataques sádicos. "Como conseqüência, o bebê sente uma necessidade crescente de ter um objeto que possa amar e pelo qual possa ser amado - um objeto perfeito, ideal - a fim de satisfazer sua ânsia de auxílio e segurança" (KLEIN, 1945/1996, p. 453).

Lembrando que tais fenômenos ocorrem sob o domínio da libido oral, Klein afirmou que o bebê introjeta seus objetos desde o início, de tal forma que as imagos primárias possuem seu equivalente no interior da criança. Assim as imagos do seio materno e do pênis paterno, tanto nos aspectos bons como nos maus, se estabelecem no interior do ego e formam o núcleo do superego. "Eles se tornam os primeiros representantes das figuras internas protetoras e auxiliadoras, de um lado, e das figuras internas persecutórias e retaliadoras de outro. Essas são as primeiras identificações que o ego desenvolve" (KLEIN, 1945/1996, p. 453-454).

Fiquei a pensar se a frustração do bebê, em função do distanciamento do seio materno, poderia levá-lo a buscar o co-gêmeo como um substituto do pênis paterno, que afasta a mãe-seio, dirigindo a ele seus impulsos agressivos.

Neste ponto, acho pertinente pensar em como poderiam se interagir as imagens dos pais como objetos externos e internos, sendo transpostas pela imagem do co-gêmeo. 
Klein ressaltou, em diversos momentos do texto, a importância da ansiedade, da culpa e dos sentimentos depressivos influenciando as relações edípicas desde o início.

Ressalto aqui, de forma especial, o medo que o bebê enfrenta de perder seus objetos de amor como conseqüência de seu ódio e agressividade, levando aos sentimentos acima mencionados. Então, fico a pensar na "onipresença" do co-gêmeo que acaba por impedir o bebê de receber a atenção materna, logo ficando privado do seio-bom e na presença do seio-mau por grande parte de tempo.

Poderia essa "presença real" do co-gêmeo fazer com que a vivência como "terceiro excluído" fosse exacerbada entre os co-gêmeos? Se assim fosse, quais seriam as conseqüências disso?

Athanassiou (1986) afirmou que os gêmeos vivenciam situações onde precisam dividir o colo, o seio e até mesmo a atenção da mãe. Sendo que, quando um recebe qualquer tipo de atenção materna, geralmente a divide em alguma proporção com o co-gêmeo, de tal maneira que dificilmente consegue ter a mãe só para si. O bebê gêmeo, enquanto está no seio, percebe seu co-gêmeo alterego -- acumulando raiva, por estar separado não apenas do seio materno como também do co-gêmeo. Assim, segundo a mesma autora, o relacionamento mãe-gêmeo está sempre sendo perturbado pela presença do co-gêmeo tanto no ambiente externo quanto na mente da mãe.

Dessa maneira é possível imaginar que o gêmeo deva vivenciar situações de "terceiro excluído" em proporção maior do que os singulares. A sensação de ser excluído leva não só a fantasias, mas até aos comportamentos agressivos propriamente ditos. É possível que os comportamentos agressivos tão freqüentes em gêmeos por volta dos 8-10 meses de vida conforme mencionados 
anteriormente, sejam decorrentes da vivência de exclusão e, portanto, de sentimentos de raiva e desejo de destruir o co-gêmeo. Certamente tais situações acabam por provocar, em alguma medida, o sentimento de culpa.

Klein enfatizou que a culpa, além de gerar a pulsão de reparação, inibe os desejos libidinais. Quando a agressividade é percebida como predominante, a criança percebe seus desejos libidinais como perigosos para os objetos amados e que devem ser reprimidos.

Klein considerou o desenvolvimento dos primeiros estágios do complexo de Édipo como sendo iguais nos dois sexos; depois de certo tempo, a evolução do fenômeno segue rotas diferentes em cada gênero. Considerou ainda a existência do complexo de Édipo direto e invertido nos dois sexos.

Quando o menino consegue transferir parte dos seus desejos libidinosos e amor pelo seio materno para o pênis paterno, mantendo ainda o seio como objeto bom, vivencia então uma situação onde considera o pênis do pai como um órgão bom e criador, capaz de gratificação libidinal, bem como lhe dar filhos tal qual o fez com sua mãe. Tais sentimentos constituem o complexo de Édipo invertido, logo a primeira posição homossexual no menino. "Pois só ao acreditar firmemente na 'bondade' do órgão genital masculino - tanto do pai quanto de si mesmo - o menino se permite sentir desejos genitais pela mãe" (KLEIN, 1945/1996, p. 455).

Se o medo do pai castrador é minimizado pela confiança no pai bom, o menino consegue lidar com o ódio e a rivalidade oriundos da situação edipiana. Percebe-se então a existência das tendências edipianas positivas e invertidas se desenvolvendo ao mesmo temo, havendo forte interação entre ambas. 
Por outro lado, se o co-gêmeo for colocado como substituto do pai na relação edípica com a mãe, como ficaria isso? De que maneira o co-gêmeo poderia ocupar o lugar do pênis bom?

O menino vive uma situação complicada, pois a imagem assustadora do "interior" da mãe, que convive com a imagem da mãe boa e gratificante, leva-o a vivenciar medos em relação ao interior do seu próprio corpo.

Dentre estes se destaca o medo do bebê ser atacado por uma mãe ou um pai ameaçador, ou então uma figura composta dos dois, como retaliação pelos seus próprios impulsos agressivos. Esses medos persecutórios influenciam decisivamente as ansiedades do menino a respeito de seu próprio pênis. (KLEIN, 1945/1996, p. 456)

O menino teme por seu pênis, bem como pelos bons conteúdos de seu corpo: boas fezes, urina e os bebês que deseja ter, em sua posição feminina. Outro tipo de ansiedade relacionada ao temor à castração é derivado das fantasias sádicas de que seus excrementos são venenosos/perigosos. O seu pênis, identificado com as fezes, torna-se um órgão de destruição nas fantasias de cópula.

Outro aspecto importante é quando o menino acredita conter em si o pênis mau do pai, ou seja, identifica-se com o pai mau e pode chegar a acreditar que teria feito uma aliança com o pai mau interno contra a mãe. Neste ponto, fiquei a pensar se o bebê poderia se imaginar criando uma dupla ou até mesmo uma "gang completa" com o co-gêmeo, buscando atacar a mãe ou o pai... Tal qual Biale (1989) sugeriu que os gêmeos acabam se organizando para realizar suas travessuras.

Klein (1945/1996, p. 460) fez um paralelo entre a teoria de Freud sobre o complexo de Édipo e a forma como ela própria o considerou, ressaltando alguns aspectos da teoria dele, tais como: o surgimento dos desejos genitais e a 
escolha do objeto ocorrendo na fase fálica, por volta de três a cinco anos; a ênfase no falo, tanto no homem quanto na mulher; a ameaça de castração provocando a destruição da organização fálica na criança de sexo masculino; o superego como sucessor do complexo de Édipo formado pela internalização das figuras parentais; a fase pré-edipiana na menina, caracterizada por grande apego à mãe; a menina desejaria receber um pênis da mãe; o clitóris representando o pênis e sendo objeto de masturbação na menina; a percepção de não possuir pênis levando a menina a se sentir castrada e culpar a mãe por isso; quando a menina percebe que a mãe também não possui pênis se afasta dela e busca o pai; o complexo de Édipo é ativado pelo complexo de castração na menina.

A seguir, apresentou algumas considerações sobre as diferenças entre suas idéias e as de Freud sobre o tema, as quais serão comentadas abaixo, nas palavras da própria autora:

De acordo com meu ponto de vista, o desenvolvimento sexual e emocional tanto do menino quanto da menina inclui, desde a mais tenra infância, sensações e tendências genitais, que constituem os primeiros estágios do complexo de Édipo positivo e invertido; elas são vividas sob a primazia da libido oral, e se misturam a desejos e fantasias uretrais e anais. Os estágios libidinais se sobrepõem desde os primeiros meses de vida. As tendências edipianas positivas e invertidas interagem entre si desde o início. É durante o estágio da primazia genital que a situação edipiana positiva atinge o seu clímax. (KLEIN, 1945/1996, p. 461)

Ressaltou que os bebês têm um conhecimento inconsciente de pênis e vagina, além disso, possuem desejos genitais em relação a seus pais.

Segundo Klein, o superego passa a existir durante a fase oral, refletindo as imagens fantásticas que existem na mente da criança. "Sob o domínio da vida de fantasia e de emoções conflitantes, a criança introjeta seus objetos antes de mais nada, os pais - em cada estágio de sua organização libidinal, 
construindo o superego a partir desses elementos" (Klein, 1945/1996, p. 461).

Acho que aqui se abre um espaço para pensar em como o cogêmeo participaria desta constituição edípica.

É possível questionar se, quando a mãe se ocupa da maternagem do co-gêmeo, o bebê poderia fantasiar que o irmão possuísse algo melhor do que si mesmo para que fosse, naquele momento, abandonado pela mãe. Penso ser interessante ligar essa idéia com as questões estudadas por Klein em relação aos conceitos de seio bom e seio mau, ressaltando os aspectos da amamentação e desmame precoce em gemelar.

Ao discorrer sobre "Os efeitos das situações de ansiedade arcaicas sobre o desenvolvimento sexual da menina" (1932a/1997), Klein comentou que a manutenção da posição feminina, na menina, vai depender não só da atitude do pai em relação a ela, mas também de como a menina percebe as relações do pai com a mãe e irmãs, bem como do seu sentimento de culpa em relação à mãe. Além disso, a morte da mãe ou de um irmão poderá afetar o sentimento de culpa e, logo, o desfecho das escolhas objetais futuras.

Comentou que o bebê divide a mãe em "boa e má" e o pai em "bom e mau", assim, quando se afasta do objeto mau, procura pela mãe boa e pai bom, e tenta restaurá-los na fantasia. A autora enfatizou, também, a importância da presença de outra pessoa, além dos pais, no início da vida da criança que seja considerada "prestativa".

Mas se, por sua ansiedade ser excessivamente grande ou por razões realistas, seus objetos edipianos não se tornaram imagos bons, outras pessoas, tais como uma babá carinhosa, irmão ou irmã, um avô ou uma tia ou tio, podem, em certas circunstâncias, assumir o papel da mãe "boa" ou do pai "bom". (KLEIN, 1932a/1997, p. 240) 
É possível conjeturar se o co-gêmeo poderia exercer essa função, considerando que, embora seja da mesma idade, poderia, ainda que momentaneamente, ser percebido pelo bebê como um bom objeto.

No mesmo texto, a autora falou sobre as relações sexuais existentes entre crianças no começo da vida, especialmente entre irmãos e irmãs como sendo algo muito comum. Tais situações, motivadas "por suas frustrações edipianas, juntamente com a ansiedade proveniente das suas mais profundas situações de ansiedade, impelem-nas a se entregarem a atividades sexuais mútuas..." (p. 241).

A leitura desse material me fez pensar, ainda mais, na importância do estudo das relações fraternas entre os co-gêmeos, pois a "onipresença" de ambos provavelmente favorece a ocorrência de interação freqüente e intensa entre si.

Acredito também que, noutros momentos, o fato de ser "deixado de lado" tantas vezes, quando a mãe se ocupa da maternagem do próprio co-gêmeo, deve favorecer os sentimentos de ódio em relação a ela, a projeção de sentimentos de retaliação e, posteriormente, a necessidade de tentar restaurar o objeto mãe.

É possível que haja situações onde os co-gêmeos busquem se unir como forma de defesa contra um ou ambos os genitores, tal qual a autora mencionou abaixo.

[...] ao realizar atos sexuais com uma outra criança ela tem o sentimento de estar em aliança com ela contra os pais. As relações sexuais entre as duas crianças tornam-nas cúmplices em um crime, revivendo nelas fantasias masturbatórias sádicas que foram originalmente dirigidas ao pai e à mãe e fazendo com que as crianças se gratificassem com elas conjuntamente. (KLEIN, 1932a/1997, p. 241) 
Ao mesmo tempo em que a criança se sente amparada pela outra compartilhando e dividindo a vivência prazerosa, partilha também o fardo da culpa, sentindo-se aliviada e menos amedrontada, "porque acredita ter um aliado contra seus objetos apavorantes" (KLEIN, 1932a/1997, p. 241).

Segundo Klein, além de essas vivências sexuais arcaicas gratificarem a libido infantil, capacitam as crianças a confirmar e/ou refutar vários medos em conexão com o ato sexual. Os irmãos, nestes casos, funcionariam como figuras "de ajuda", contribuindo de forma favorável para o desenvolvimento sexual posterior da menina, contribuindo para a manutenção da posição feminina e sua capacidade de amar.

Em alguns dos casos que tenho em mente, a menina teve dois tipos de objeto de amor, um que representava o pai severo e o outro o irmão carinhoso. Em outros casos, ela havia desenvolvido uma imago que era uma mistura dos dois tipos, e aqui também suas relações com o irmão haviam diminuído seu masoquismo. (KLEIN, 1932a/1997, p. 241)

Klein afirmou que essas relações fraternas contribuem também para que a menina, apoiada na realidade externa, tenha uma prova da existência do pênis bom, assim as relações com o irmão tanto fortalecem a crença no pênis "bom" introjetado quanto ajuda a dominar o medo dos objetos "maus" introjetados.

Klein fez algumas considerações a respeito da maneira como a menina se relaciona com a sua maternidade futura. Lembrou que, para Freud, a menina teria o desejo de ter um filho como substituto do desejo de possuir um pênis, entretanto segundo as observações dela "o que precede seu desejo por um filho é o desejo pelo pênis do pai em um sentido de objeto libidinoso oriundo de sua posição oral" (KLEIN, 1932a/1997, p.245). 
A equação feita pela menina poderia envolver crianças e fezes ou crianças e pênis. Sendo que, no primeiro caso, a relação com a criança se faz segundo linhas narcísicas, havendo uma atitude mais independente dos homens e mais intimamente relacionada com o próprio corpo e a onipotência de seus excrementos. Além disso, mencionou a existência de uma teoria sexual infantil universal de que "a mãe incorpora um pênis novo toda vez que ela copula e que esses pênis, ou uma parte deles, se transformam em crianças" (KLEIN, 1932a/1997, p.245). Logo, a relação da menina com o pênis do pai estaria ligada inicialmente com as crianças imaginárias e, mais tarde, com os seus filhos reais.

A equação entre fezes e criança também afeta a relação da criança pequena com seus bebês imaginários e, posteriormente, as fantasias da menina em relação aos seus excrementos "venenosos e escaldantes" poderiam formar a base dos sentimentos de ódio e medo, levando às tendências de expulsar a criança real do útero da gestante.

A autora lembrou que a criança imaginária, de certa forma, proporciona proteção e ajuda à menina pequena, já que representaria os bons conteúdos de seu corpo. Por outro lado, mencionou também o fato de a menina realizar ataques imaginários ao corpo materno, utilizando-se dos seus excrementos venenosos e destrutivos.

Se considerarmos a equação entre fezes e bebês como possibilidade de representação de crianças más dentro do útero, é possível se pensar na possibilidade de a menina e, futuramente, mulher grávida fantasiar a existência de bebês bons ou maus em seu útero.

Caso a hipótese seja verdadeira, seria possível imaginar que, na gravidez gemelar, a gestante poderia fantasiar a existência de dois bebês, segundo 
a equação pênis=bebês, fezes=bebês ou até um bebê representando cada uma das equações. Logo, resultando em atitudes diferentes na relação entre a mãe e cada co-gêmeo.

A mãe de gêmeos poderá perceber em cada bebê gêmeo características diversas, em função das suas próprias relações arcaicas. "Esses relacionamentos emocionais que ela teve na infância arcaica com respeito ao pai, tios e irmãos ou com respeito à mãe, tias e irmãs se refletirá em maior ou menor grau na criança, de acordo com o seu sexo" (KLEIN, 1932a/1997, p. 248).

A autora lembrou que, para a mãe, o nascimento de uma criança implica em fantasias de restauração do interior do seu próprio corpo, das crianças imaginárias, dos irmãos e irmãs que temia ter danificado com seus ataques sádicos, bem como o pênis paterno.

Acredito que o relacionamento que a mãe de gêmeos tiver vivenciado com os seus respectivos irmãos poderá influenciar maneiras diferentes de se relacionar com os filhos gêmeos. Se a hipótese for verdadeira, é possível que a mãe fique mais ligada a um dos co-gêmeos em detrimento do outro, por exemplo.

Klein descreveu a maneira como concebia as características da sexualidade nas crianças de ambos os sexos, ressaltando as diferenças entre meninos e meninas. Acreditava que a maneira de controlar a ansiedade é diferente nos dois sexos: a menina tenta atacar os objetos maus internalizados com seus excrementos; já o menino tenta fazê-lo de modo ativo por intermédio da onipotência de seu pênis, tanto na tentativa de controlar os objetos internos quanto os externos.

O fato de o menino perceber que ocorrem alterações anatômicas no próprio pênis, ajuda-o a acreditar que possui um órgão poderoso e onipotente, 
muitas vezes usado de forma sádica. Assim, fantasia tomar posse do corpo da mãe, acreditando que, ao copular com ela, poderia conquistar o mundo externo ao mesmo tempo em que controlaria o modelo masculino. Assim, tanto no ato sexual quanto nas sublimações, o menino busca deslocar as situações de perigo para o mundo externo e, ao mesmo tempo, superá-las com a onipotência do seu pênis.

Klein (1932b/1997, p. 261-262) apresentou outra grande diferença entre meninos e meninas: nelas, a crença no "pênis bom" do pai fortalece as tendências introjetivas, "o teste de realidade contra seus objetos 'maus', realizado pela mulher, se dá, em última instância, dentro de si mesma, uma vez mais". Nos meninos, "a crença em uma mãe 'boa' internalizada e o medo de objetos 'maus' o ajudam a deslocar para fora seus testes de realidade (isto é, para dentro de corpo da mãe)".

O ódio do menino ao pênis do pai o impulsiona a desejar copular com a mãe. Além disso, gradativamente o menino passa a temer que o pênis do pai, no interior da mãe, seja um perigo não apenas para ele - menino, mas também poderia destruir o corpo dela. Assim, o menino deseja destruir o pênis paterno dentro da mãe.

Outro fator que impulsiona os anseios do menino em realizar o coito é o desejo de conhecer o interior do corpo da mãe, tentando descobrir que tipo de destruição teria sido ocasionada pelo seu pênis e excrementos, bem como os do pai.

Por essa época em que o menino está dominado pelo sadismo e impulsos agressivos, existe também um impulso para tentar dominar a ansiedade através de satisfação genital. Fator este importante para incrementar o desenvolvimento. 
Se as imagos de cada um dos pais "bons" estiverem atuando com força suficiente, lado a lado com a imagem dos pais combinados, o menino gradativamente vai melhorando sua relação com os objetos e assim a adaptação à realidade irá contribuir para que a fantasia do pênis dentro da mãe perca seu poder. Dessa maneira, a imago dos pais combinados vai sendo dissipada, levando-o a percebê-los em imagens isoladas e o menino passa a dirigir seus impulsos libidinais para a mãe, ficando o ódio e a ansiedade voltadas para o pai real (ou pênis do pai). Klein ressaltou que, por deslocamento, o ódio ao pai pode ser dirigido a outros objetos.

Isso me leva novamente a pensar na possibilidade de o bebê gêmeo deslocar seus impulsos de amor ou de ódio para a figura do co-gêmeo, que seria colocado como um dos vértices do triângulo edípico.

O caso abaixo ilustra como a autora percebeu as relações fraternas em um de seus pacientes, cuja vida erótica era dominada por dois tipos de objeto: "Esse tipo correspondia a seu irmão David. [...] O segundo tipo correspondia ao outro irmão, Leslie. Costumava se apaixonar profundamente por esse tipo de pessoa e aí tinha uma real adoração pelo pênis dela" (KLEIN, 1932b/1997, p. 288).

O estudo das relações fraternas levou-me a refletir sobre os sentimentos de ciúmes e inveja que poderiam estar presentes em tais situações.

Klein falou sobre a questão da inveja e do ciúme vivenciados pelo bebê em relação ao seio materno, considerando haver "uma ligação direta entre a inveja vivenciada em relação ao seio da mãe e o desenvolvimento do ciúme. O ciúme se baseia em suspeita e rivalidade com o pai, que é acusado de ter levado embora o seio materno e a mãe" (KLEIN, 1957/1991, p.228). 
Nesse momento, fiquei pensando se, em bebês gêmeos, poderiam ocorrer sentimentos semelhantes em relação ao co-gêmeo que muitas vezes "rouba", literalmente falando, o seio da mãe. Levando em consideração a minha hipótese de que a triangulação inicialmente poderia ser entre os co-gêmeos e a mãe, é possível que essa inveja e também o ciúme aconteçam precocemente pelo fato de o bebê ser "abandonado" pela mãe, todas as vezes em que amamenta o cogêmeo, podendo despertar todo o mecanismo anteriormente descrito em relação ao pai.

Ao falar sobre o fenômeno edípico, de forma geral, Klein mencionava a possibilidade de os sentimentos hostis serem deslocados para outras figuras e assim haveria a possibilidade de mitigar os sentimentos de inveja e ciúmes inicialmente dirigidos aos genitores.

Se a inveja não é excessiva, o ciúme na situação edipiana torna-se um meio de elaborá-la. Quando o ciúme é vivenciado, os sentimentos hostis são dirigidos não tanto contra o objeto originário mas principalmente contra os rivais pai ou irmãos -, o que introduz um elemento de distribuição. Ao mesmo tempo, quando essas relações se desenvolvem, dão origem a sentimentos de amor e tornam-se uma nova fonte de gratificação. (KLEIN, 1957/1991, p.230)

Acredito que entre os gêmeos a situação fica mais complicada porque, embora os sentimentos de inveja e ciúmes possam ser deslocados do pai para o co-gêmeo, acabam sendo dirigidos ainda a um dos objetos mais importantes e presentes na vida de cada bebê. Se assim for, esses sentimentos poderiam ser até exacerbados ao invés de mitigados!

Klein ressaltou que a inveja de cada genitor pode ser minimizada na medida em que o bebê desloca o seu ódio para o genitor do sexo oposto, que julga possuir aquilo que era tão desejado no primeiro (mãe ou pai), de forma tal que a 
inveja, neste caso, acaba sendo elaborada através do ciúme. Lembrando que "a elaboração da inveja por meio do ciúme é, ao mesmo tempo, uma defesa importante contra a inveja. O ciúme é sentido como muito mais aceitável e origina menos culpa do que a inveja primária que destrói o primeiro objeto bom" (KLEIN, 1957/1991, p.230).

Acho importante relacionar o ciúme com as situações onde basta um bebê ser atendido pela mãe para que o co-gêmeo, que antes estava tranqüilo, começar a chorar e/ou engatinhar até a mãe, e além disso, relacionar com situações onde o pai é o objeto de ciúme.

A autora ressaltou que a criança pode realizar uma fuga para outros objetos como forma de defender a mãe/seio, tanto amada quando invejada. Entretanto, se "a inveja e o ódio são predominantes, essas emoções são transferidas, em certo grau, para o pai ou para os irmãos, e mais tarde para outras pessoas, e daí por diante o mecanismo de fuga fracassa" (KLEIN, 1957/1991, p.249).

É possível que as emoções negativas possam ser deslocadas para o co-gêmeo, gerando não só fantasias como também comportamentos agressivos. Comportamentos estes que poderiam acontecer de forma mais intensa quando o bebê precisa aguardar pelos cuidados de maternagem que a mãe proporciona ao co-gêmeo, deixando excluído o primeiro, ao menos momentaneamente.

Por outro lado, o texto abaixo que levou-me a pensar na possibilidade de o co-gêmeo desenvolver uma "melhor capacidade de espera" enquanto a mãe realiza a maternagem do co-gêmeo. "Ao internalizar o seio tão vorazmente que na mente do bebê o seio se torna inteiramente posse sua e por ele controlado, o bebê sente que tudo que ele atribui ao seio será dele próprio. Isso é 
usado para contrabalançar a inveja" (KLEIN, 1957/1991, p.250).

Ao analisar as questões relativas ao desmame, Klein ressaltou que na posição depressiva ampliam-se as relações de objeto, por volta da metade do primeiro ano de vida, havendo uma ampliação da importância do pai para o bebezinho. Se for nesta ocasião que o pai passa a ter uma melhor significância na mente do bebê, fiquei a pensar em que época o co-gêmeo passaria a ter um significado como objeto na mente do bebê.

Essa é uma das questões que me intrigam muito! Embora ainda não tenha uma idéia clara sobre o assunto, o trecho abaixo, no qual Klein falou sobre uma menininha $(B)$, cuja situação edípica iniciou-se primeiro com o irmão e depois foi transferida para o pai, levou-me a ficar mais propensa a acreditar que a percepção de um outro (bebê até!) poderia ser bastante precoce e que o segundo objeto de amor poderia ser outro irmão, talvez o co-gêmeo em vez do pai!!!

A partir dos quatro meses em diante a relação com seu irmão, vários anos mais velho do que ela, desempenhou um papel proeminente e marcante em sua vida. Essa relação diferia de várias formas, como podia ser facilmente visto, da relação com a mãe. Ela admirava tudo que seu irmão dizia e fazia, e cortejava-o persistentemente. Usava de todos os seus truquezinhos para engraçar-se e chamar sua atenção, e exibia uma atividade visivelmente feminina em relação a ele. Naquele tempo o pai estava ausente, exceto por períodos muito breves, e foi apenas quando tinha dez meses que passou a vê-lo mais frequentemente, e dessa época em diante desenvolveu uma relação muito mais próxima e amorosa com ele, que em alguns pontos essenciais assemelhavam-se à relação com o irmão. No começo do segundo ano ela frequentemente chamava o irmão de "Papai". Nessa época o pai tinha-se tornado o favorito. O prazer em vê-lo, o enlevo quando ouvia seus passos ou sua voz, os modos pelos quais ela o mencionava repetidas vezes em sua ausência, e muitas outras expressões de seus sentimentos por ele, podem apenas ser descritos como estando apaixonada. A mãe reconheceu claramente que nesse estágio a menininha de algum modo gostava mais do pai do que dela. Temos aqui um exemplo da situação edípica inicial que, foi vivenciada primeiro em relação ao irmão e então transferida para o pai. (KLEIN, 1952/1991, p. 137) 
Noutro momento, Klein mostrou o quanto o bebê, já no quinto mês de vida, reage de forma diferente com as pessoas. Considerando que bebês gêmeos muitas vezes são colocados muito próximos entre si, geograficamente falando, é possível que estabeleçam um relacionamento interpessoal "de fato" entre ambos com poucos meses de vida. "No quinto mês distinguia claramente entre 0 pai, a mãe e a empregada, e o demonstrava inequivocamente em seu olhar de reconhecimento e em sua expectativa de certos tipos de brincadeira de cada um deles" (KLEIN, 1952/1991, p. 140).

Levando em consideração os aspectos até aqui mencionados, fico sempre a imaginar a necessidade de realizar estudos observacionais, em situação natural, para melhor compreender as questões da gemelaridade. Klein já havia percebido e enfatizado a importância desse tipo de pesquisa:

A vida mental de um bebê muito pequeno é ainda um mistério para a maioria dos adultos. Eu me aventuro a sugerir que uma observação mais atenta de bebês, estimulada pelo maior conhecimento dos processos mentais arcaicos derivado da psicanálise de crianças pequenas, deve com o tempo levar a uma melhor compreensão da vida emocional do bebê. (KLEIN, 1952/1991, p. 143) 


\subsection{OBservaçÃo de BebÊs}

Klein falou de forma bastante efusiva sobre a necessidade da observação para melhor compreender o que se passa no início da vida e também sobre o desenvolvimento do psiquismo da criança. Alegou que muitas de suas conclusões teóricas foram derivadas de observação de crianças bem pequenas. Entretanto, ressaltou as dificuldades e limitações dessa metodologia de estudo, pois: "os processos inconscientes são apenas parcialmente revelados no comportamento, seja de bebês, seja de adultos. Tendo em mente tal reserva, podemos obter alguma confirmação dos achados psicanalíticos em nosso estudo de bebês" (KLEIN, 1952/1991, p. 120).

Continuou, dizendo que a observação de bebês precisa ser realizada de forma "aguçada", pois, embora o bebê não consiga falar, é possível inferir a sua comunicação através de outros meios que não a linguagem verbal. Para compreendê-lo, "necessitamos não apenas um conhecimento maior mas também uma plena empatia com ele, baseada em estar nosso inconsciente em contato íntimo com o inconsciente dele" (KLEIN, 1952/1991, p. 120). Uma outra ressalva é o fato de os bebês serem afetados de maneira intensa por fatores externos, tanto favoráveis quanto desfavoráveis.

As idéias acima mencionadas dão notícia das dificuldades de observar os bebês, mas também da importância de se usar a observação de bebês para confirmar as descobertas que a autora fez por meio do atendimento psicanalítico de sua clientela.

Klein mencionou o fato de o bebê precisar se adaptar às condições 
ambientais desde o nascimento.

As relações do bebê com seu primeiro objeto, a mãe, e com o alimento estão inseparavelmente interligadas desde o início. Portanto, o estudo dos padrões fundamentais das atitudes em relação aos alimentos parece ser a melhor aproximação à compreensão dos bebês. (KLEIN, 1952/1991, p. 121)

Algumas falas da autora deixaram evidentes as diferentes atitudes do bebê durante a amamentação desde os primeiros dias de vida, sendo importante observar também a maneira como a própria mãe manipula e alimenta o filho.

Isso me levou a pensar sobre a importância de analisar os episódios de amamentação, no peito, bem como a forma como mãe e gêmeos se relacionam durante os momentos de alimentação via mamadeira e através de maneiras alternativas (colheradas, pequenos pedaços de alimentos), considerando aqui se a mãe alimenta um gêmeo por vez ou os dois bebês ao mesmo tempo.

Klein apresentou alguns exemplos do que percebeu na relação mãe-bebê, tais como:

\begin{abstract}
Vi bebês de apenas três semanas interromperem suas mamadas por um breve momento para brincar com o seio da mãe ou para olhar para o rosto dela. Observei também bebês pequenos - até mesmo com apenas dois meses de vida -, nos períodos despertos após as mamadas, deitados no colo da mãe, olharem para ela, ouvirem sua voz e a ela responderem através de expressões faciais - era como uma conversa amorosa entre mãe e bebê. Tal comportamento implica que a gratificação está tão relacionada com o objeto que dá o alimento quanto com o próprio alimento. (KLEIN, 1952/1991, p. 122)
\end{abstract}

Enfatizou que esses comportamentos da dupla mãe-bebê poderiam dar uma idéia de como serão as relações interpessoais e também o desenvolvimento emocional daquela criança. Além disso, mencionou a existência de um ego primitivo que "já é em alguma medida capaz de suportar a frustração e 
ansiedade e de lidar com elas" (KLEIN, 1952/1991, p. 122). Todavia, deixou clara a idéia de que o meio ambiente, representado muitas vezes pelos cuidadores, vai contribuir para que o bebê funcione com maior ou menor ansiedade. "Ao mesmo tempo somos levados a pensar que a capacidade inata para amar que se revela em uma primeira relação de objeto só pode desenvolver-se livremente porque a ansiedade não é excessiva" (KLEIN, 1952/1991, p. 122).

O texto acima me levou a pensar na capacidade dos bebês de poder lidar de foram razoável com a espera pelo atendimento do co-gêmeo desde o início da vida, dependendo, é claro, da maneira como a mãe auxilia os bebês a lidarem com suas frustrações e mostrando que ela está presente e atenta às necessidades de ambos os bebês.

É interessante lembrar dos trabalhos desenvolvidos por Szejer (1999) junto às mães, a qual acredita que o bebê é bastante sensível às atenções que recebe do meio, sendo especialmente afetado pelas emoções e falas maternas. Descreveu vários casos atendidos em maternidade onde pode conversar com as mães e seus filhos recém-nascidos, demonstrando que os bebês foram capazes de reagir às conversas da psicanalista em idade muito precoce.

Dessa maneira, é possível que as falas da mãe com cada um dos co-gêmeos possa interferir na maneira como os bebês percebem a presença e os cuidados da mãe, tanto ao cuidar de si como do irmão, mesmo ao longo do primeiro ano de vida.

As colocações acima sugerem a importância da realização de estudos observacionais para buscar entender o que se passa na relação mãe-bebê e suas implicações para o desenvolvimento psíquico. 
Embora enfatizasse o estudo do mundo interno do bebê, Klein apresentou algumas idéias a respeito de como as vivências com o seio materno e também a forma como recebe a mamadeira contribui para o estabelecimento das relações objetais.

Acho interessante lembrar que a autora enfatizava que, conquanto buscasse compreender as fantasias e, logo, o mundo interno das crianças, considerava essencial o contato com as experiências vividas no mundo externo para melhor compreender o psiquismo do bebê.

Desde a sua origem, a psicanálise sempre enfatizou a importância das primeiras experiências da criança, mas parece-me que somente desde que conhecemos mais sobre a natureza e os conteúdos de suas ansiedades arcaicas e o contínuo interjogo entre suas experiências reais e sua vida de fantasia é que estamos plenamente capacitados a compreender por que o fator externo é tão importante. (KLEIN, 1952/1991, p. 124-125)

Klein falou sobre os comportamentos apresentados pelos bebês, nos momentos em que são alimentados e dão indícios dos seus sentimentos e desejos vivenciados em tais situações. Um dos aspectos analisados foi o dos bebês muito vorazes, os quais dão sinais de ter grande interesse pelas pessoas. Às vezes é algo tão exacerbado que parecem necessitar mais da "atenção" do que da própria pessoa. São crianças que têm dificuldade de ficarem sozinhas, desejando a gratificação da mesma forma - voraz - de buscar pelo alimento: "isso indicaria que a voracidade é reforçada pela ansiedade e que há um fracasso tanto em estabelecer com segurança o objeto bom no mundo interno quanto em desenvolver confiança na mãe como um objeto bom externo" (KLEIN, 1952/1991, p. 125-126).

Por outro lado, se a criança apresenta dificuldade ou recusa pelo alimento, associada à deficiência no estabelecimento de relações de objeto, isso 
poderia indicar a presença de mecanismos paranóides e esquizóides, típicos da posição esquizoparanóide, sugerindo ainda "que os impulsos destrutivos e a ansiedade persecutória prevalecem, que as defesas do ego são inadequadas e a modificação da ansiedade é insuficiente" (KLEIN, 1952/1991, p. 126).

Outro aspecto considerado são as relações de objeto deficientes, típicas de crianças muito vorazes, para as quais o alimento parece funcionar como se fosse "quase que a fonte exclusiva de gratificação, e desenvolve-se pouco interesse por pessoas. Eu concluiria que elas também não elaboram com sucesso a posição esquizo-paranóide" (KLEIN, 1991-c/1952, p. 126).

Assim, Klein foi explicando o valor da observação como reveladora de muitos fenômenos que o bebê estaria vivenciando. A maneira como cada bebê reage às situações em que ocorre frustração, por exemplo, é bastante interessante. Alguns podem recusar o alimento ou demonstrar a sua perturbação através de outros sinais, sendo possível ter uma idéia a respeito da qualidade da relação mãebebê em tais circunstâncias.

Bebês que demonstram prazer na alimentação e amor pela mãe
toleram mais facilmente a frustração na alimentação; a perturbação
resultante na relação com a mãe é menos grave e seus efeitos não
perduram durante muito tempo. Isso é uma indicação de que a
confiança na mãe e o amor por ela são relativamente bem
estabelecidos. (KLEIN, 1952/1991, p. 126-127)

A maneira como o bebê reage à introdução da mamadeira dá indícios de como está lidando com a perda (parcial ou total) do seio. Alguns bebês se ressentem muito como se houvesse uma perda do objeto bom primário e também uma privação imposta pela mãe 'má', assim, "a ansiedade persecutória e a desconfiança provocadas por essa experiência podem perturbar a relação com a mãe e assim incrementar ansiedades fóbicas" (KLEIN, 1952/1991, p. 127). 
Entretanto, outros bebês aceitam o novo alimento com menos ressentimento, demonstrando maior tolerância à privação, denotando não necessariamente uma submissão e sim uma relação mais segura com a mãe, capacitando o bebê a aceitar o novo alimento e ao mesmo tempo manter o amor pela mãe.

Klein (1952/1991, p. 128-129) relatou o caso de uma criança de cinco meses que certo dia ficou chorando por um tempo maior que o habitual. Quando a mãe foi atendê-la, encontrou-a em estado "histérico". "A bebezinha parecia aterrorizada, estava evidentemente com medo dela e não parecia reconhecê-la. Somente depois de algum tempo, é que $B$ restabeleceu plenamente contato com sua mãe". A hipótese levantada pela autora foi que o fato de a mãe não ter atendido no momento desejado fez com que fosse transformada na mãe má ("persecutória"), levando assim a não ser reconhecida pela filha, que ficou com medo dela.

O exemplo acima mencionado levou-me a pensar sobre as situações onde os dois bebês gêmeos requisitam a atenção materna e apenas um de cada vez consegue ser cuidado. Desse modo, um dos co-gêmeos precisa aguardar por mais tempo, podendo sofrer as conseqüências da frustração.

Ao longo do mesmo texto, a autora foi descrevendo outros momentos em que os bebês expressam (através de choro, alterações faciais e movimentos corporais) suas emoções, tanto de alegria quanto de ansiedade, medo, etc., chegando a afirmar que: "Se essas perturbações são muito freqüentes e de longa duração, podem ser tomadas como uma indicação de que o bebê não está lidando eficientemente com a posição esquizo-paranóide" (KLEIN, 1952/1991, p. 130).

Chamou a atenção, também, para a sutileza do que se pode captar 
pela da observação de bebês, afirmando que certas crianças que "choram pouco" podem ser consideradas "alegres e boas", entretanto continuou relatando ter analisado alguns adultos e crianças que viveram dificuldades desde a primeira infância, haviam sido bebês semelhantes àqueles, tendo concluído que "muitos desses bebês são de fato mentalmente doentes e retraídos do mundo externo devido à intensa ansiedade persecutória e ao uso excessivo de mecanismos esquizóides" (KLEIN, 1952/1991, p. 130).

Em outros exemplos, sinalizou para a possibilidade de inferir o estado mental dos bebês, a partir da observação, tais como: “... a bebezinha $B$, de cinco meses de idade, estava com medo de sua mãe, que, em sua mente, tinha se transformado da mãe boa na má, e que essa ansiedade persecutória também perturbava seu sono" (KLEIN, 1952/1991, p. 131).

Klein mencionou alguns sinais comportamentais que podem ser utilizados como guias para se detectarem as ansiedades vivenciadas pelos bebês a partir da posição depressiva:

Nesse estágio as ansiedades persecutória e depressiva expressam-
se de formas variadas, como por exemplo em uma maior irritação,
uma necessidade maior de atenção ou um afastamento temporário
da mãe, ataques súbitos de cólera e um medo maior de estranhos.
Também crianças que normalmente dormem bem algumas vezes
soluçam durante o sono ou acordam chorando de repente, com
sinais claros de medo ou tristeza. Nesse estágio a expressão facial
muda consideravelmente - a capacidade maior de percepção, o
interesse maior pelas pessoas e coisas e a pronta resposta a
contatos humanos refletem-se na aparência da criança. Por outro
lado, há sinais de tristeza e sofrimento que, embora transitórios,
contribuem para que o rosto se torne mais expressivo de emoções
de natureza mais profunda quanto em maior variedade. (KLEIN,
1952/1991, p. 132) Davison (1992) citou o trabalho de Stern (1985) que propunha uma 
distinção entre a 'criança clínica' e a 'criança observada' como um caminho para preservar a observação empírica e inferir as informações coletadas com as crianças. Stern acreditava que a experiência subjetiva das crianças poderia apenas ser inferida pelo fato de elas ainda não usarem a fala. Davison concordava em parte com a idéia dele, entretanto dizia que, se fosse sempre assim, a mãe poderia ficar totalmente desnorteada com sua nova criança, ao passo que, em geral, muitas mães são hábeis em interpretar os estados subjetivos de seus filhos e são sensíveis às insinuações corretivas que os seus bebês lhes dão.

Davison acreditava que a observação naturalista de crianças oferece a terceira perspectiva sobre a criança humana em algum lugar entre a clínica de Stern e as crianças observadas. O observador necessita prestar atenção seletivamente, interpretar o que é observado de acordo com ambos: préconcepções teóricas e preconceitos pessoais. Além disso, precisa relembrar e registrar uma fração da experiência total. Tal processo poderia dar a impressão de ter uma pobre sustentação para ser científica. Contudo, se aceitarmos que os humanos começam sendo unicamente programados para serem sensíveis às sugestões sociais (HOBSON, 1990, apud DAVISON, 1992) e aos processos de identificação projetiva e introjetiva (KLEIN, 1946/1991), através dos quais os bebês comunicam às mães e observadores os seus sentimentos, então a observação naturalista tem um lugar no incremento do nosso conhecimento a respeito do desenvolvimento infantil.

Davison mencionou alguns trabalhos nos quais foram realizadas observações naturalistas, visando analisar as diferenças de temperamento apresentado por gêmeos, tais como Gilford et al., (1966), Abrams (1986) e, especialmente, Zazzo (1977), que mostrou que gêmeos monozigotos criados 
separados são mais similares com respeito a certos traços de personalidade do que outros criados juntos.

Dentre os trabalhos citados por essa autora, chamaram a atenção algumas pesquisas (AINSLIE, 1985, LEONARD, 1961, MCLEAN; JONES, 1987, apud DAVISON, 1992) que usaram o esquema desenvolvimentista proposto por Mahler (1982) para sugerir a existência de uma 'simbiose psicológica' durante a fase simbiótica (2-6 meses), atribuindo aos gêmeos a tarefa adicional de desenvolvimento de separar-se do outro tão bem quanto separar-se da mãe, isto é, acreditando que eles começam num estado de identificação primária um com o outro.

A observação de bebês certamente é algo que pode ser utilizado como estratégia para compreender o que acontece nas relações entre os bebês e seus cuidadores. Uma das pessoas que mais valorizou a observação foi Esther Bick, chegando a criar o Método de Observação Psicanalítica das Relações MãeBebê, o qual tem sido utilizado em diversos países como parte da formação dos psicanalistas.

Aqui, no Brasil, contamos com vários profissionais que vêm usando essa metodologia. Tive o privilégio de fazer o curso de Observação de Bebês, com as psicanalistas Marisa P. Mélega e Daise Bracco, nos anos de 1997 e 1998. Seguem abaixo algumas explicações do método as quais foram retiradas do relatório final que apresentei em tal curso. Preferi neste momento manter o estilo de redação daquela época, sem mencionar tanto as referências bibliográficas, visando dar uma idéia do que apreendi durante as vivências de observação naqueles dois anos.

O trabalho de observação de bebês, baseado no método de Esther 
Bick, funciona como uma forma de desenvolver uma série de atitudes do analista, no relacionamento com o paciente.

O contrato feito com os pais deve ter as mesmas características do contrato psicanalítico, pois se deve preservar o setting das observações. Sendo assim, é fundamental que se estabeleça um horário semanal a ser seguido, o qual deverá ser mantido independentemente dos atropelos do dia-a-dia, isto é, a observadora deverá estar na residência do bebê no horário previamente definido; caso a mãe e a criança não estejam em casa, deverá esperar pelo retorno, a menos que seja informada de que não deverão retornar até o término do horário; caso isto ocorra, poderá ir embora, deixando um bilhete informando que esteve lá; se a mãe convidar para ir a algum lugar, a observadora deverá acompanhar a dupla mãebebê; se o bebê permanecer em casa, sem a mãe, a observação deverá ser feita mesmo assim, a menos que a família não aceite.

Se por algum motivo o observador não puder comparecer no horário da observação, o horário não deverá ser reposto, apenas se mantém o mesmo horário na semana seguinte. Caso a família informe que não estará disponível em algum dia, deve-se manter o horário na semana seguinte, sem reposição. Em ambos os casos, é preciso fazer uma reflexão a respeito dos motivos que levaram ao cancelamento de cada sessão de observação. Se houver mudança de horário, é a mãe quem deve propor reposição. O setting é determinado pela mãe e não pela observadora.

As férias devem ser combinadas com antecedência, se não houver coincidência nos períodos de férias da família e da observadora, não há necessidade de reposição dos horários.

Durante as observações, nada deverá ser anotado. Entretanto, 
deve-se procurar fazer o relato logo após cada observação. Deve-se procurar anotar os fatos de acordo com a seqüência em que ocorreram. É preciso anotar apenas o que ocorreu, evitando a "não-conduta" aquilo que não ocorreu (por exemplo: o bebê olhou para a mãe, mas não sorriu), pois expressa apenas os desejos do observador e não o comportamento do bebê.

A família toda pode participar da observação, no entanto a observadora deverá manter o foco de atenção no bebê, na relação mãe-bebê. Os parentes que circularem na residência deverão ser denominados do ponto de vista do bebê, por exemplo, avó paterna em vez de sogra da mãe.

O relato escolhido para ser supervisionado ${ }^{5}$ deverá conter um cabeçalho com o nome da observadora, idade atual do bebê, número da sessão de observação e data. Devem ser feitas cópias para todos os integrantes do grupo, inclusive as duas supervisoras, independentemente de quem irá supervisionar o grupo naquela data.

Caso os pais perguntem se haverá relatórios das observações, deve-se explicar que, se quiserem, no final da experiência, poderemos conversar sobre o que ocorreu ao longo dos dois anos. Em hipótese alguma deverão ser mostradas as anotações.

Deve-se prestar atenção na forma como as vivências provocam emoções no observador. É preciso analisar os pensamentos que surgem, visando perceber a transferência que está acontecendo entre mãe e observadora. Procurase analisar o efeito desta transferência no observador, lembrando que a mãe irá

\footnotetext{
${ }^{5}$ Durante o curso de observação de bebês, realizado mensalmente, cada observadora levava o relatório de uma sessão para ser supervisionada.
} 
fazer identificações projetivas no observador. Deve-se verificar como o observador percebe em si mesmo todas estas coisas.

Pode-se treinar a capacidade negativa, quando a mãe não informa coisas que o observador poderia/gostaria de saber. Não se deve ficar investigando dados, buscando informações além do que se extrai da observação; deve-se esperar o momento em que aquela pessoa quiser informar. Deve-se evitar a intrusão do observador onde ainda não Ihe foi exposto. Sendo assim, deve-se esperar que o assunto apareça e não tentar extraí-lo da pessoa observada. A ênfase do trabalho é observar as relações interpessoais, logo os dados/informações sobre a família não são necessários/importantes.

É como na agricultura ... : deve-se esperar a fruta amadurecer e não arrancá-la da planta antes do tempo.

A observadora não deve interferir na dinâmica das pessoas observadas, sendo assim deve se conter para não atender o bebê lembrando que está ali para observar, nada mais. Quem deverá atender às necessidades do bebê são os integrantes da família e/ou os substitutos dos pais.

Se o bebê chorar, convém aguardar a vinda da mãe, pois a interferência da observadora poderá impedir que a mãe atenda ao chamado do bebê. Além disso, se a mãe demora, o bebê busca formas de se conter, seja fixando o olhar em algum ponto do ambiente, etc.

A ansiedade do bebê pode-se manifestar através de comportamentos mais rápidos, agitados, etc. Entretanto, é preciso cautela, pois pode haver interferência das sensações da observadora e não das emoções do bebê. É preciso aguardar, perceber a seqüência dos acontecimentos, para então 
analisar.

\section{Observador só observa!}

Embora a função do observador seja esta, é interessante perceber que a sua presença ajuda a mãe a organizar os seus próprios pensamentos. Fato este de certa forma captado por uma das mães, a qual perguntou a uma das nossas colegas (psicólogas que participavam do mesmo curso) quanto os pais deveriam “pagar à psicóloga" pelo trabalho que seria realizado em sua residência...

Através da relação mãe-bebê, é possível captar o mundo psíquico. Muitas coisas que a princípio não são percebidas, vão sendo mais bem compreendidas com o decorrer das observações.

Na clínica, o terapeuta entra em contato com objetos internalizados do paciente e vai observando como cada um se relaciona com os outros (mãe interna, pai interno e outros). Durante as observações, quando se entra em contato com o psiquismo que está sendo estruturado, tem-se a possibilidade de analisar as relações entre o bebê e as figuras parentais.

O observador, de certa forma traz notícias do mundo externo (exemplo: está frio lá fora?), já que a dupla mãe-bebê parece reclusa no seu mundo interno. Tudo isso tem a ver com a "preocupação materna primária" (Winnicott, 1983), estado este que a mãe desenvolve durante a gestação e faz com que esteja com uma ansiedade (não neurótica), sentindo-se responsável pela sobrevivência do bebê. O exercício da função de mãe, que no início parece exagerada, é importante para o estabelecimento do vínculo mãe-bebê, o qual constitui a base da estrutura psíquica.

A observação do bebê auxilia a lidar com o desconhecido, pelo fato 
de não se saber o que irá encontrar na criança, na relação mãe-bebê, etc. Isto nos remete à situação terapêutica em que também não sabemos o que iremos encontrar a cada sessão com o paciente.

Assim, ao se questionar - como observar - verifica-se que é preciso nos despir daqueles preconceitos que temos e ficarmos bem livres destas idéias para observarmos objetivamente o campo emocional entre a mãe e a criança.

É comum haver uma transferência da mãe em relação à observadora, da mesma forma que ocorre em outros relacionamentos humanos, que acontecem com uma freqüência regular de encontros. Há necessidade de a observadora delimitar melhor seu papel, cuidando para não estimular uma situação transferencial intensa, pois não poderá ser trabalhada terapeuticamente. Deve-se cuidar para não transpor os limites do papel de observadora.

Pelo fato de estarmos em contato com a vida rotineira das famílias, enquanto observadoras, deparamo-nos com situações de dor com as quais precisamos conviver. Essa convivência com a dor que temos que enfrentar ao presenciar os problemas das famílias dos bebês é similar às situações de dor dos pacientes com as quais temos que conviver na clínica.

Os momentos mais difíceis da observação parecem ser o início, período do nascimento, e o desmame, quando há grande probabilidade de a mãe vivenciar a depressão pós-parto.

Ao se manter no seu papel, a observadora pode mostrar à família como deveria olhar para o bebê. Na observação psicanalítica há necessidade de não apenas olhar para o bebê, mas principalmente manter a "atenção flutuante" para captar o clima do ambiente familiar. 
O método Esther Bick serviu como inspiração para a realização do presente trabalho. Digo "inspiração" porque não foram utilizados todos os quesitos sugeridos por Bick. Priorizei, sim, a constância dos horários/dias da semana, a não interferência nas atividades da família, a atenção flutuante, a realização de anotações logo após as sessões de observação, o relato dos comportamentos apresentados pelos bebês e seus cuidadores além dos sentimentos vivenciados por mim - observadora - em cada situação. Quando afirmo ter utilizado parte da metodologia proposta por Bick, refiro-me ao fato de não ter sido acompanhada por um grupo de observadoras que pudesse estar auxiliando na interpretação dos fenômenos observados durante toda a realização da pesquisa. Para tanto, teria sido necessário que um grupo de observadoras se dispusesse a acompanhar todo o trabalho durante os cinco anos da coleta de dados. Considerando que o método Bick tem sido utilizado mais pelos psicoterapeutas e psicanalistas que não estão ligados à vivência acadêmica, mas aos consultórios particulares, ficou impossível mobilizar colegas que pudessem me auxiliar nesta empreitada sem que houvesse alto custo financeiro pelas horas trabalhadas.

A experiência por mim vivenciada ao longo do curso de Observação de Bebês foi extremamente importante para a formação como Psicoterapeuta sob o enfoque psicanalítico, além de contribuir para a minha atitude como pesquisadora. Aliás, Peres-Sanchez (1983, p.11) comentou que Esther Bick dizia: “a Observação de Bebês pode ser utilizada como aprendizagem para a coleta de dados e a formação do pensamento científico".

Bick (1987 apud KOMPINSKY, 2000, p. 18-19) enumerou vários argumentos ressaltando a importância da observação de bebês, dentre eles: auxiliar na compreensão da experiência da criança e do bebê, bem como sua comunicação 
não verbal e manifestações através do brincar; possibilitar a aprendizagem sobre os comportamentos do bebê; perceber como se iniciam as relações do bebê com a mãe e a família, além de ser uma fonte de coleta de dados e de conhecimento científico.

Sendo assim, acredito ser a Observação de Bebês um bom instrumento para compreender o que se passa no início da vida dos gêmeos, uma vez que existe pouca bibliografia, principalmente sobre as relações objetais neste universo de estudo.

Mélega (sem data) apresentou a descrição de um seminário clínico onde foi analisada uma sessão de Observação Psicanalítica Método Esther Bick, durante a qual foi observado um dos bebês trigêmeos de uma família. O trabalho privilegiou a análise do grupo participante do seminário, entretanto é possível perceber o quanto foi difícil para a observadora relatar as cenas onde estavam presentes dois ou mais bebês. Além disso, também foi interessante perceber que a observadora dava notícias sobre o acontecia na relação entre a mãe e os cogêmeos:

\footnotetext{
A mãe está atrapalhada, em "desordem", e acredito que isto se deva a presença de muitas pessoas na casa. Eu acho que são os bebês. Um quer andar, outro quer não sei que. Ela corre para atender um, corre para acudir o outro. Os bebês mudaram. Não são mais aqueles bebês que ela põe no carrinho, e ali ficam. (p. 24)
}

O objetivo daquele relato não era a relação objetal dos gêmeos e, sim, a observação de um dos co-gêmeos, entretanto pôde dar notícia de como a interação mãe-bebês era intensa e poderia motivar novos trabalhos de pesquisa.

Encontrei o relato de uma experiência realizada num hospital onde a equipe de pediatria observou três pares de gêmeos: "nossas observações, de 
duração de mais ou menos uma hora, seguiam o método da atitude participativa, ensinada por Esther Bick, e começavam, quando era possível, logo após o nascimento, desde as primeiras horas de vida da criança" (CRESTI; LAPI, 1997, p. 151). O material coletado era discutido com a equipe do hospital, tendo como objetivo relacionar a princípio a díade mãe-bebê e depois relacionar com a "tríade" mãe/bebê/hospital. O trabalho ilustra como o método Bick pode influenciar e motivar a realização de pesquisas utilizando a observação de bebês como instrumento de coleta de dados.

No texto supramencionado, foi possível perceber tanto as angústias da mãe ao ter que lidar com os dois co-gêmeos recém-nascidos, bem como o papel da equipe hospitalar funcionando como "um envelope que contém e protege" ( $p$. 155) a dupla mãe-bebê, dando sustentação à mãe e ao mesmo tempo levando-a a pensar sobre o que vivenciava com cada filho. Em relação ao fato de a mãe ser observada pela observadora:

A atenção que esta dá às crianças parece estimular a "curiosidade" da mãe em relação aos bebês, e uma maior possibilidade de "pensar" neles e reconhece-los pelas diferenças de comportamentos, como se pouco a pouco fosse aprendendo a compartilhar e assimilar suas capacidades de observação empática (CRESTI; LAPI, 1997, p. 155).

Isso demonstra não só o aspecto de poder pesquisar as relações entre mãe e gêmeos mas também ressalta o aspecto psicoprofilático que a observação pode produzir ao longo da pesquisa.

Davison (1992) relatou uma experiência de observação através do método Esther Bick, em que acompanhou um par de gêmeos masculinos semanalmente, durante o primeiro ano de vida, e mensalmente, durante o segundo ano. Quando entrei em contato com o seu texto, fiquei encantada pelo fato de ela 
estar realizando um trabalho semelhante ao que há muito tempo eu pensava em realizar.

Acho interessante citar aqui algumas vivências por ela mencionadas para se ter uma idéia do tipo de análise que realizou e que certamente estarão subsidiando esta pesquisa.

Ao invés de colocar o texto na forma original, em inglês, optei por comentar algumas situações descritas pela autora em relação às observações dos gêmeos.

Davison enfatizou que descreveu os comportamentos dos gêmeos e seus cuidadores da mesma forma que outras pessoas poderiam observar os bebês em situação natural. Além de relatar os comportamentos dos gêmeos, colocou algumas falas da mãe e as análises que ela própria realizou a respeito dos dados coletados em sua função de observadora.

Uma das primeiras dificuldades enfrentadas pela mãe foi encontrar um local afetivo para dois bebês em sua mente. Um dos bebês permaneceu hospitalizado, enquanto o outro já estava em casa. Quando o segundo gêmeo teve alta, a mãe se percebeu pensando algo do tipo "Não, você pode ficar com ele, eu já tenho meu bebê (Mark). Eu não preciso de um outro!" Para ela, ter dois bebês não parecia ser algo natural $^{6}$.

Em alguns momentos, Davison falou sobre a dificuldade da mãe em manter cuidar de um bebê e simultaneamente dar a atenção ao co-gêmeo. Em tais situações, formava-se uma tríade, onde, se a mãe dava atenção a um bebê, o co-

\footnotetext{
6 “... she found herself thinking 'No, you can keep him, l've got my baby (Mark). I don't need another one!" (DAVISON, 1992, p. 362).
} 
gêmeo ficava na situação de terceiro excluído, se atendia ao segundo bebê, a situação se invertia, e houve momentos em que a própria mãe se sentia como "a excluída".

Durante os primeiros três meses de vida dos gêmeos, a mãe se sentia muito confusa para cuidar dos gêmeos, mas Davison (1992) considerou que, por volta do final do primeiro trimestre, cada criança já tinha estabelecido ou reconhecido um relacionamento com a mãe boa. Entretanto, eles demonstravam competição com o outro nas situações onde ambos estivessem com a "mesma mãe boa". Uma solução a que a família encontrou era que os gêmeos deveriam ser acordados alternadamente.

Segue abaixo a tradução de uma vinheta de observação (DAVISON, 1992, p. 364), em que a mãe precisou cuidar dos dois gêmeos:

\begin{abstract}
Mark começou a chorar, então a Sra. Finch deixou Luke rindo sobre a esteira enquanto buscou Mark. Luke imediatamente começou a chorar. Ele não estava de qualquer forma consolado pelo reaparecimento da mãe com Mark. Mark entretanto estava consideravelmente calmo, então sua mãe o colocou deitado e ele com toda esperteza procurou sua chupeta e a chupou. Luke fixou imediatamente sua mãe relacionando-se com ela ao invés disso, mas naquele momento em que ela tentou distraí-lo ou deitá-lo ele gritava. Em uma ocasião ele estava em pé no colo de sua mãe olhando para Mark embaixo. Ele não poderia ser descrito como muito feliz, mas melhor olhando para baixo sobre seu irmão do que sendo colocado embaixo.
\end{abstract}

Situações como esta dão a idéia de como mãe e gêmeos passam por dificuldades quando ambos co-gêmeos necessitam ou desejam ser cuidados pela mãe. Por mais que ela seja habilidosa e suficientemente boa, é impossível atender aos dois bebês ao mesmo tempo!

Numa outra vinheta (Davison, 1992, p. 364), traduzida, é possível ter uma idéia do quanto cada co-gêmeo pode viver momentos de frustração, de 
raiva e possivelmente de contato com o seio bom que se transforma em seio mau, pelo fato de a mãe ter que se ausentar, mesmo que apenas momentaneamente para cuidar do co-gêmeo:

Como o choro de Luke tornou-se sempre mais alto e mais insistente, a Sra. Finch finalmente disse a Mark 'Eu sinto muito eu vou deixar você e espero que tenha tido o bastante'. Ela retirou seu mamilo da boca de Mark, colocou-o em sua esteira e voltou sua atenção para Luke, que estava agora completamente fora de si com raiva. Ela estava curiosa em saber se ele ainda estava com fome e ofereceu a ele o outro peito. Inicialmente ele estava chorando muito ao pegar o mamilo, mas gradualmente ele acalmou o suficiente para sugar. Ele poderia não fixar propriamente, não obstante, e se afastou por três vezes, ainda chorava se a Sra. Finch o afastasse do peito. Houve alguma coisa distintamente menos agradável nesta troca. Luke tinha recuperado a posse do 'seu' peito mas eu não acho que tenha sido uma boa experiência. Sua raiva era inconfundível, e no processo o peito da sua mãe tinha perdido a bondade.

A partir de aproximadamente quatro meses, a mãe passou a introduzir alimentos sólidos, entretanto o momento das refeições eram permeados por um relacionamento furioso, cada gêmeo apresentava grande impaciência quando não recebia o alimento no momento que solicitava e ficava vigiando, tossindo, como se uma colher cheia de comida tivesse desaparecido dentro da boca do outro! Davison (1992, p. 364) não tinha dúvida de que certamente um dos motivos da confusão sobre a comida era que se um fosse mais lento em abrir a boca, perdia sua vez. A autora dizia que testemunhar o co-gêmeo ser alimentado produzia impaciência em cada gêmeo, o qual não estava motivado apenas pela fome. A urgência e a ganância mostravam também ser agravadas pelo sinal do outro estar sendo alimentado, possivelmente provocando sentimentos de estar sendo deixado de lado. Certamente, a experiência de ser deixado de lado poderia não ser maior do que o mencionado simplesmente como projeção da mãe.

As situações triangulares foram muito freqüentes nas vinhetas 
envolvendo os gêmeos e sua mãe. Davison (1992, p. 365) comentou:

O ponto que eu desejo enfatizar, entretanto, é que aos 3 meses os gêmeos raramente estavam cônscios de não ser cada outro: Mark poderia tolerar a mãe atendendo a Luke, mas não a visão de Luke amamentado no peito. Ele 'sabia' que ele não estava tendo alguma coisa que Luke estava tendo naquele momento e que isso era muito desejado também. Aos 4 meses era levemente mais complicado onde Luke começou a protestar quando a mãe deixava o quarto e podia não ser também estranho pensar que ela retornaria com Mark parecendo a ele uma traição. Seus gritos amáveis e risadas não eram suficientes, Mark tinha apenas que chorar do quarto próximo para roubar sua mãe de volta para ele, e então insultos eram adicionados para injuriar quando Mark era amamentado no peito a despeito da insistência de Luke de que ele queria a mãe para si mesmo.

À medida que os gêmeos foram ficando mais velhos, as situações triangulares continuaram a ocorrer, entretanto os bebês já conseguiam reagir melhor ao fato de precisarem dividir a atenção da mãe entre si. Entretanto, quando uma pessoa estranha chegava a casa, por exemplo, ambos recorriam à mãe numa atitude bastante paranóide e até aparentemente regressiva.

Em diversos momentos do texto, Davison abordou a questão do quanto deve ser doloroso para os gêmeos suportar não ser o único e o quanto afeta ao gêmeo deixado de lado abrir mão do prazer que poderia obter com a mãe caso pudesse usufruir da interação dela com o co-gêmeo que está 'in', ou seja, recebendo, ele também, a atenção materna naquele momento.

Um outro aspecto mencionado por Davison foi que, ao final do primeiro ano de vida, os gêmeos, tal qual a mãe deles imaginara, desenvolveram entre si um vínculo mais profundo, pois pareciam estar se descobrindo como companheiros de folguedos.

Por essa época, a autora recordou os trabalhos de vários autores (FREUD; DANN,1951; LEONARD,1961; DIBBLE; $\quad$ COHEN, 1981 e 
ATHANASSIOU,1986, apud DAVISON, 1992) enfatizando que a simbiose gêmeogêmeo compete no mínimo com, se não a suplanta, a união simbiótica de cada criança com a mãe. Além disso, Davison acreditava que a Mãe poderia estar sendo vista como uma figura que perturba a simbiose gemelar e apresenta a si mesma como um objeto que provoca rivalidades entre os gêmeos pelos favores dela. 


\section{MÉTODO}

Será realizada uma investigação psicanalítica em contexto domiciliar, onde serão estudados os fenômenos presentes na relação gemelar e entre gêmeos e seus cuidadores.

Participarão do estudo cinco pares de gêmeos recém-nascidos e suas respectivas famílias, sendo: dois pares monozigotos, sendo um par masculino e outro feminino; três pares dizigotos, sendo um par feminino, um masculino e um de sexos diferentes ${ }^{7}$.

Neste estudo, a maneira como os pais percebem os gêmeos e se relacionam com eles é o aspecto mais importante, logo a zigozidade foi considerada a partir das informações dadas pelos pais, que, por sua vez, fundamentaram-se nas avaliações dos respectivos pediatras.

As famílias de participantes do projeto serão recrutadas a partir de contatos realizados com ginecologistas, pediatras e fisioterapeutas que trabalham com gestantes.

A coleta de dados será realizada nas residências das famílias.

Inicialmente será realizada uma entrevista com os pais de cada par de gêmeos, preferencialmente durante o período de gestação.

\footnotetext{
7 “é importante que os psicanalistas estejam cônscios das diferentes formas de zigosidade de gêmeos e, se possível, determinem a natureza da zigosidade de seus objetos de estudo específicos. A interidentificação mútua ocorre tanto entre gêmeos idênticos quanto fraternais, mas outros fenômenos podem não ocorrer" ( JOSEPH, 1975, p.107).
} 
Durante a entrevista a metodologia utilizada será explicada: a observadora permanecerá na residência durante uma hora semanal, sempre no mesmo horário e dia da semana, desde o nascimento dos gêmeos até o final do primeiro ano de vida; não será realizada qualquer intervenção, por parte da observadora, em relação ao que estiver ocorrendo na família; preferencialmente deverão manter a rotina da casa, de tal forma que se os bebês estiverem dormindo, por exemplo, serão observados mesmo assim; será mais conveniente que os horários sejam marcados nos períodos em que a mãe esteja presente. Caso ela precise se ausentar deverá estar presente outro adulto responsável pela família.

Durante o período da observação, permanecerei no cômodo da casa onde se encontrarem os dois bebês ou, se estiverem em locais diferentes da residência, ficarei naquele local oferecido pela mãe ou substituta, podendo me deslocar pela casa em função dos translados aos quais os bebês forem submetidos.

Procurarei interferir o mínimo possível na situação, procurando manter-me em silêncio e com atenção flutuante e observar o que acontece, tanto em relação a cada bebê, quanto na interação mãe-bebê, gêmeo/co-gêmeo, mãegêmeos, pai-gêmeos, gêmeos e demais pessoas presentes.

Durante a observação, não será realizada qualquer anotação. Após cada visita, será elaborado um relatório constando os fenômenos observados, descrevendo não apenas os comportamentos dos presentes, mas também as minhas percepções e interpretações dos fatos.

O método de observação Esther Bick foi utilizado como inspiração para a realização da coleta de dados por ser considerado uma das formas mais adequadas de se inserir no interior da residência da família e captar os fenômenos que ali são vivenciados pela mãe e seus filhos gêmeos, na companhia do pai e 
demais elementos da família. Trata-se de uma forma menos invasiva do que se usasse de artifícios de gravação ou filmagem, por exemplo.

A análise dos dados será realizada através de diferentes vértices:

Verificar de que maneiras os co-gêmeos se relacionam, visando analisar a partir de que idade parecem se perceber como pessoas, ou seja, quando e como apresentam mudanças no comportamento a partir da presença do cogêmeo.

Inicialmente, a análise dos dados será realizada, por meio do levantamento dos fenômenoss observados, englobando os comportamentos apresentados pelos gêmeos, tanto individualmente, quanto na interação com o respectivo co-gêmeo e demais pessoas presentes na situação de observação.

Posteriormente, pretendo estudar, especialmente, as situações triangulares onde estiverem envolvidos os gêmeos e a mãe.

Serão priorizadas as situações de alimentação, higiene e brincadeiras, nas quais serão analisados os fenômenos observados na relação mãe-gêmeos, considerando a triangularidade da situação, tais como:

1. Comportamentos apresentados pelos gêmeos nas situações em que a mãe cuida de uma das crianças, através da troca de fraldas e outras atividades, quando apenas um dos gêmeos recebe colo e/ou atenção da mãe a fim de verificar como os co-gêmeos reagem.

\footnotetext{
8 "O objetivo de qualquer técnica é ajudar o fenômeno a revelar-se de forma mais completa do que o faz na experiência usual. [...]revelar-se de forma mais completa significa revelar camadas de significação. No aparecimento geral de um acontecimento, suas significações estão presentes em nosso ato de experienciar este aparecimento, mas estão implícitas e obscuras." (KEEN, 1979, p.
} 
2. Situações onde estavam presentes o par de gêmeos, a mãe e o pai, visando analisar as interações entre eles.

3. Análise de situações onde houver disputas por brinquedos ou outros objetos pelos gêmeos.

4. Verificar de que maneiras os co-gêmeos se relacionam, nas diversas situações, principalmente quando a mãe estiver presente na cena.

A análise dos dados será qualitativa.

Considerando que a psicanálise tem como uma das pedras fundamentais as relações de objetos, considerando ainda que o conceito de Édipo diz respeito a situações onde três objetos estão implicados, abrindo pois o caminho para a triangulação ${ }^{9}$, é possível questionar se o fato de os gêmeos vivenciarem situações triangulares precocemente poderia provocar algum desfecho diferente daqueles vivenciados pelos indivíduos singulares.

Pretendo fazer uma correlação entre os dados coletados e a literatura vigente relacionada às questões do Édipo Precoce. Espero poder verificar os fenômenos presentes na interação entre gêmeos e seus pais, uma vez que dificilmente, nos primeiros meses de vida, o gêmeo tem oportunidade de permanecer numa relação apenas dual com a mãe ou seu substituto.

\footnotetext{
34)

9 "O complexo de Édipo abre o caminho para a triangulação, permitindo a inclusão do pai, assim estabelecendo a diferença de gerações , potência e outras diferenças indispensáveis para uma evolução exitosa da criança." (ZIMERMAN, 2001, p.75).
} 


\section{RESULTADOS}

A observação dos cinco pares de gêmeos ocorreu em suas próprias residências, durante o primeiro ano de vida. Os horários das observações priorizavam os momentos em que a mãe estivesse presente com os gêmeos, sendo que, na maioria das vezes, foram marcados em situação onde o pai estava ausente em função da sua atividade profissional.

Visando dar uma idéia de como eram as famílias dos gêmeos, farei um breve comentário a respeito de cada uma delas.

G1: sexo feminino, dizigotos, um irmão de 8 anos, residiam com os pais e avós maternos.

G2: sexo feminino, monozigotos, uma irmã de cinco anos, residiam com os pais.

G3: gêmeos de sexo diferente, logo dizigotos, um meio-irmão de treze anos por parte de pai (morava com sua mãe), residiam com os pais.

G4: sexo masculino, monozigotos, residiam com os pais.

G5: sexo masculino, dizigotos, uma irmã de quatro anos e um irmão de um ano, residiam com os pais.

A pesquisa visava compreender as relações entre os bebês e seus pais, que os consideravam gêmeos idênticos ou fraternos, logo não foram 
realizados testes para avaliar a zigosidade, sendo a mesma informada pelos respectivos pais.

Os gêmeos G1 e G5 apresentavam características faciais bastante diferentes. No par G1, uma das gêmeas era loira e a outra morena, apresentavam diferença de peso de aproximadamente um quilo desde o nascimento até o final do primeiro ano de vida. No par G5, além das diferenças faciais, um dos co-gêmeos nasceu com defeito físico: não possuía a mão esquerda.

Nos pares G2 e G4, a semelhança física entre os co-gêmeos era tão grande que frequentemente eram confundidos pelos próprios integrantes da família, inclusive os pais.

As observações se iniciaram entre o nascimento e a terceira semana, continuando até o final do primeiro ano da vida dos gêmeos. O número de observações realizadas variou em função de situações familiares, do tipo viagens ou consultas médicas, que impediam a presença dos gêmeos na residência, ficando o total de observações assim distribuídas: G1 - 47; G2 - 41; G3 - 42; G4 - 42 e G5 $-39$.

A maneira como os gêmeos eram cuidados pelos pais apresentou características específicas em cada par, entretanto foi possível perceber algumas semelhanças, dentre elas a utilização de objetos que nomeei como extensores de colo: carrinhos/cadeiras de bebê, berço/cama, colchões colocados no chão e andadores. Os extensores de colo foram utilizados em várias situações, principalmente quando a mãe se encontrava sozinha para cuidar dos co-gêmeos. 
diversos fenômenos, dos quais, para este trabalho, escolhi os seis tipos abaixo listados:

\author{
Atendimento individual mãe-gêmeo. \\ Atendimento conjunto mãe-gêmeos. \\ Disputa do colo/atenção materno. \\ Atendimento individual pai-gêmeo. \\ Atendimento conjunto pai-gêmeos. \\ Relacionamento gêmeo-gêmeo.
}

Visando dar uma idéia do que se passava nas observações selecionei algumas vinhetas dos fenômenos mais freqüentes, as quais serão descritas a seguir.

Para tornar a leitura das vinhetas de observação mais agradável, resolvi colocar nomes fictícios nos gêmeos em vez de identificá-los apenas por códigos: G1 - (A) Carol e (B) Inês; G2 - (A) Ana Flávia e (B) Ana Maria; G3 (A) Kátia e (B) Luiz; G4 - (A) Gustavo e (B) Fernando; G5 - (A) Mário e (B) Romário. Escolhi nomes com sonoridade semelhante para os pares G2 e G5, gêmeos considerados idênticos, pois seus verdadeiros nomes também possuíam tais características. Os nomes verdadeiros dos demais pares eram bem diferentes entre si.

Os fenômenos mais freqüentes serão comentados a seguir. 


\subsection{Atendimento individual mãe-gêmeos}

Esta situação acontecia quando a mãe dedicava atenção e cuidados total ou quase exclusivamente a um dos bebês, enquanto o co-gêmeo dormia e/ou estava presente na cena e não recebia atenção da mãe.

Três fenômenos se destacaram:

A mãe atende um bebê enquanto o co-gêmeo reclama através de choro.

A mãe cuida de um bebê enquanto o co-gêmeo aguarda, estando presente no mesmo local, sem apresentar qualquer reclamação.

Revezamento sono e vigília - um bebê está acordado enquanto o co-gêmeo dorme.

Durante as primeiras oito semanas, nos pares 1, 2 e 3, foram observadas diversas cenas onde um bebê era atendido enquanto o outro chorava. Foi possível perceber que embora um dos co-gêmeos ficasse temporariamente "abandonado", a mãe dividia sua atenção entre ambos, pois o "bebê cuidado" não era sempre o mesmo.

G1, 4 semanas: A mãe retirou Inês do berço e a colocou na cama para fazer a troca de fraldas; assim que a mãe a retirou do berço e conversou com ela, parou de chorar. Enquanto isso, Carol chorava no berço, a mãe por vezes olhava para ela, mas dizia à avó que era assim mesmo, ela sabe que tem que esperar quando mama no peito para depois ganhar a mamadeira. Carol chorava bem alto e forte. 
G1, 7 semanas: Passados poucos minutos, Carol começou a chorar, a mãe a carregou dizendo você também quer mamazinho, vem, a mamãe dá para você. Imediatamente após ser colocada ao peito, Carol começou a mamar, mantendo o olhar fixo no rosto da mãe. Logo a seguir, Inês começou a resmungar, a mãe lhe falou você já mamou, agora é a vez da irmãzinha, ela esperou você mamar sem chorar, não precisa fazer assim...

G2, 6 semanas: Passados alguns minutos, Ana Flávia começou a resmungar mais forte, então a mãe tirou o mamilo da boca de Ana Maria dizendo que ela já tinha parado de sugar e a colocou na cama. O bebê ficou quieto por alguns minutos. Então a mãe carregou Ana Flávia e ofereceu o peito, assim que a mãe tirou o peito direito e 'quase' colocou na boca de Ana Flávia, que praticamente não tinha aberto a boca, Ana Maria começou a chorar forte.

G3, 3 semanas: A mãe colocou Kátia na posição vertical, apoiada em seu colo e pedia para a bebê arrotar. Pouco depois, Luiz começou a resmungar. Logo a seguir, a mãe retirou o termômetro e foi buscar um copinho descartável para dar leite ao Luiz. Colocou o bebê sentado em sua perna esquerda, colocou uma toalha de banho sob o queixo e ofereceu o leite, sendo que o bebê tomou umas três pequenas porções que a mãe ofereceu. A mãe comentou muito que acha Luiz mais frágil do que Kátia. Acredita que precisa cuidar muito dele, pois qualquer coisa pode afetá-lo, pode adoecer... Enquanto dava leite para ele, Kátia acordou e começou a chorar forte. 
Por volta de seis semanas, na maioria dos pares de gêmeos, começaram a aparecer cenas onde um bebê era atendido enquanto o co-gêmeo aguardava.

G1, 11 semanas: Inês começou a chorar. A mãe conversou dizendo que precisava brincar como a irmãzinha estava fazendo, sem chorar. Inês parecia prestar atenção à mãe, sorria, mas logo recomeçava a chorar. Quando Inês começou a chorar, Carol sorriu. Neste momento pensei "será que Carol percebeu a presença da irmã e por isso sorriu?" Deve ter sido coincidência, mas a idéia aconteceu em $\operatorname{mim}$.

G2, 6 semanas: A mãe guardou o peito e colocou Ana Flávia na cama, o bebê ficou em silêncio. A mãe tentou acalmar Ana Maria com palavras, assim o bebê se calou e continuou com os olhos fechados.

G5, 8 semanas : Ocasionalmente a mãe foi ao quarto e numa das vezes chegou a comentar o fato de Romário estar de olhos abertos e quieto durante o dia, enfatizando que isso não era comum. Passados uns vinte minutos de observação, Mário começou a chorar, logo a mãe veio e o atendeu. Conversou carinhosamente com o bebê e o retirou do carrinho. Cheirou suas roupas na altura dos seus genitais e traseiro, então o chamava de bebê fedido, que havia cagado e mijado, embora as palavras fossem grosseiras, seu tom de voz e semblante eram carinhosos.

No par G3, o fenômeno já ocorria a partir da segunda semana de 
vida:

Encontrei a mãe no quarto dos bebês. Luiz estava no berço, acordado. Kátia estava mamando no peito direito.

Nos gêmeos masculinos (G4 e G5), o fenômeno aguardar para ser cuidado foi muito freqüente por volta de 18 a 34 semanas.

G4, 19 semanas: Fernando estava deitado no berço, onde estavam pendurados os dois bichinhos de pano que eu havia presenteado no Natal. Cada brinquedo estava perto de uma das extremidades do berço, nas posições onde os bebês costumavam ficar deitados. Fernando olhava em direção ao brinquedo, agitava os braços e ocasionalmente batia com uma das mãos no bichinho, entretanto percebia claramente a não intencionalidade do bebê. Seu semblante era alegre e por vezes sorria. Gustavo estava deitado na cama, a mãe sentou perto do bebê, falou com ele questionando se estava com fome, se queria leite, o bebê reagia olhando em direção à mãe e sorrindo. A mãe carregou Gustavo, deitou-o no colo e deu a mamadeira que o bebê sugou imediatamente. A mamadeira estava lotada de leite! Durante o vestir as roupas, a mãe conversava com o bebê, que sorria e vocalizava. Ao final, a mãe deixou Gustavo deitado na cama e foi buscar Fernando, que começara a chorar, no berço. A mãe sentou na cama ao lado de Gustavo, carregando Fernando, então deitou no colo e ofereceu a mesma mamadeira que Gustavo havia usado. Fernando sugou alguns goles.

G5, 20 semanas: A mãe levou a mamadeira até a sala de TV e falou com os bebês perguntando quem ia mamar primeiro. Olhou para um 
e outro e então falou que ia dar primeiro para Mário. Não consegui perceber qual critério a mãe teria usado para fazer a escolha, aparentemente aquele bebê que olhou para ela por mais tempo. A mãe aproximou-se do carrinho de Mário, ajeitou o corpo dele e colocou o bico em sua boca, o bebê aceitou a mamadeira e sugou imediatamente. Enquanto segurava a mamadeira de Mário a mãe conversava com a irmã e o irmão caçula, dizendo para a garota deixar que o irmão brincasse com o presente, que ela não poderia pegar dele, etc. Enquanto isso, Mário sugava a mamadeira com o olhar fixo na mãe. Romário olhava também para a mãe.

O revezamento sono e vigília aconteceu com muita freqüência nos cinco pares observados, principalmente na faixa etária de 6 a 25 semanas. Muitas vezes, ficava a impressão de que os gêmeos alternavam os estados de sono e vigília de forma tal que conseguiam assim garantir o atendimento individual e exclusivo por um tempo maior. Logo, funcionando como se a mãe tivesse apenas um bebê para cuidar.

G1, 6 semanas: Carol continuava resmungando, a mãe Ihe falava que já ia ganhar o leite que a avó foi preparar. Logo em seguida a avó entregou para a mãe a mamadeira de leite. A mãe colocou Carol na cama, com a cabeça sobre um travesseiro, então colocou uma fralda abaixo do queixo e Carol começou a se virar para o lado direito, abrindo a boca como se tentasse abocanhar um mamilo. A mãe colocou a mamadeira apoiada pela fralda e Carol mamou ali deitada na cama. A mãe a olhava, por vezes arrumava a mamadeira, depois saiu do quarto. A mãe voltava de tempos em tempos, olhava o fundo da mamadeira de tal forma que parecia estar verificando se 
havia leite no bico. Por vezes ajeitava a mamadeira e saía novamente. Enquanto isso, Inês dormia, às vezes se movimentava, chegando a virar a cabeça de um lado para o outro. A mãe a olhava, enquanto arrumava a mamadeira de Carol.

G2, 9 semanas: Ana Flávia estava dormindo e a mãe a colocou no berço, então voltou à sala e levou o carrinho de Ana Maria para o quarto também, me convidando para ir até lá. Ana Maria estava acordada, quieta. A mãe falou com o bebê que iria lhe dar mamá. A mãe saiu do quarto levando algumas peças de roupa que estavam sobre a cômoda do quarto. (...) Ocasionalmente a mãe tentava perceber se os bebês haviam dormido e assim eu falei que Ana Maria estava com os olhos fechados, e Ana Flávia abertos. Fiz isso porque os bebês estavam de bruços, nos braços da mãe que não conseguia ver suas faces.

G3, 13 semanas: Enquanto dava o leite para Luiz, a mãe comentou que ele já estava pesando 5200 g e Kátia, 5400g. Entretanto, Luiz é mais guloso, mama cerca de $150 \mathrm{ml}$, enquanto a co-gêmea se satisfaz muitas vezes com 90 a 100ml. Assim, a mãe acha que logo ele estará mais pesado do que a irmã. Kátia fechou os olhos e parecia estar dormindo. A mãe esticou o pescoço, tentando ver a filha e me perguntou se Kátia havia dormido, respondi que estava com os olhos fechados.

G4, 19 semanas: Aos poucos Gustavo foi ficando sonolento, até adormecer. A mãe o aconchegou ao colo, levantou e foi em direção 
ao quarto. Imaginei que o tivesse colocado no berço. A mãe retornou à sala imediatamente e carregou Fernando, colocou-o sentado em seu colo e seguiu-se um "diálogo" entre mãe-bebê, as vocalizações de Fernando apresentavam uma certa entonação e ritmo como se estivesse conversando e ambos sorriam muito. Fernando regurgitou algumas vezes, molhando a sua roupa e a da mãe. A mãe o limpou com fralda e continuou a "conversa", que agora versava sobre o fato de ele ter lavado a mãe. O bebê regurgitou mais umas duas vezes e a mãe disse que ia precisar tomar banho, pois ele havia ficado fedido. Após regurgitar pela ultima vez, o bebê riu alto!

G5, 22 semanas: Romário voltou a resmungar, agora a mãe o carregou novamente, imediatamente ele calou. Enquanto isso, Mário foi ficando cada vez mais quieto e aparentando sonolência até fechar os olhos.

Percebi também que, em algumas épocas, um dos gêmeos recebia atenção materna na maior parte do tempo, fato que por vezes persistia por algumas semanas (G5-b da 21a à $26^{\mathrm{a}}$. semana e G5-a da $27^{\mathrm{a}}$. à $34^{\mathrm{a}}$. semana). Não foi possível descobrir o que teria levado cada co-gêmeo a requisitar mais ou menos a mãe em tais situações, nesses períodos.

G5, 21 semanas: A mãe entrou no quarto onde Romário chorava e retornou carregando o bebê. Enquanto isso, Mário continuava no carrinho praticamente em silêncio, olhava para a TV, para o ambiente, olhava em direção a mão direita ou toco esquerdo, colocava a mão na boca. A mãe pegou outro carrinho de bebê que estava na sala de visita, levou até a sala de TV e colocou ao lado do 
carro de Mário. Então deitou Romário no carrinho e ele chorou. A mãe o carregou novamente e conversou com ele; logo depois recolocou-o no carrinho e desta vez ele ficou quieto.

G5, 22 semanas: Romário voltou a resmungar, agora a mãe o carregou novamente, imediatamente ele calou. Enquanto isso, Mário foi ficando cada vez mais quieto e aparentando sonolência até fechar os olhos.

G5 23 semanas: A mãe foi até o sofá e conversou com Romário, o bebê continuava chorando e ela o carregou novamente, chamando-o de preto feio, questionando para que chorar tanto, dizia que ele só queria colo, etc. Para se aproximar de Romário a mãe passava em frente a Mário, que olhava para a mãe a maior parte do tempo, dando a impressão de estar buscando um pouco da sua atenção. A mãe neste momento parecia só "ter olhos" para Romário. Mário aguardava quietinho.

G5, 25 semanas: Enquanto isso, Romário havia "perdido a mamadeira", que havia caído de sua boca e ficava com a boca aberta como se procurasse o bico perdido. A mãe voltou e recolocou a mamadeira na boca de Romário que continuou sugando por mais alguns minutos. A mãe segurava a mamadeira e mantinha o olhar voltado para a tv. Logo Romário parece ter parado de sugar, a mãe afastou a mamadeira e o bebê continuou com os olhos fechados até o final do horário. Enquanto isso, Mário estava em silêncio, em seu carrinho. Eu não conseguia visualizar o seu rosto, entretanto era 
possível perceber que durante vários minutos ele voltava a face para o lado direito e aproximava a mão direita que ele movimentava, provavelmente olhando para a mão e dedos.

G5, 27 semanas: A mãe colocou Mário no carrinho e o bebê reclamou. A mãe conversou com ele tentando convencê-lo a ficar no carrinho, mas o bebê continuava resmungando e esticando o corpo, como se tentasse levantar. Assim a mãe o carregou novamente, falava com o Mário como se brigasse com ele dizendo que era um folgado, que só queria saber de colo, etc. Embora suas palavras fossem rudes, o gesto de carregar era carinhoso. Enquanto isso, Romário olhava para a mãe e para o co-gêmeo com o semblante sereno e atento.

G5, 29 semanas: A mãe permaneceu na sala por uns 10 minutos, mantendo Mário em seu colo, durante este tempo Mário ficava quietinho olhando ao redor, por vezes o seu olhar passeava pelo irmão (singular), TV, mãe e, principalmente, mantinha o olhar colado em mim. Este fato parecia estar incomodando a mãe, que em vários momentos comentava o fato, sorrindo, embora falasse que o bebê estava me estranhando, noutros momentos enfatizava que ele tem estranhado as pessoas... Em outros momentos, a mãe falava que Mário não parava de olhar em minha direção e eu cheguei a falar $o$ que será que ele pensa a respeito dessa mulher que vem aqui e fica a olhar para ele... A mãe respondia com sorrisos. Enquanto a mãe 
manteve Mário em seu colo, Romário permaneceu deitado no colchão, olhava ao redor, fixando o olhar na TV, nos próprios pés ou mãos, olhava em direção à mãe, em direção a mim. Seu semblante era sereno, aparentando estar tranqüilo naquela situação. Aparentemente o fato de a mãe estar com Mário em seu colo não interferia nos comportamentos de Romário.

G5, 25 semanas: Num certo momento, Mário tombou para trás e bateu a cabeça numa parte mais dura do carrinho, chorando muito e a mãe o acalentou. Romário neste momento ficou quieto, de certa forma aguardando enquanto a mãe cuidava do co-gêmeo.

Nos demais pares, essas situações foram menos comuns em relação ao atendimento individual.

Convém assinalar que, no par G5, com 23 semanas de idade, houve uma situação em que um dos co-gêmeos recusou receber carinho materno após aguardar que a mãe cuidasse do co-gêmeo. Nos demais pares, o fenômeno não foi observado.

Romário continuava chorando mesmo depois que a mãe o carregou, ela Ihe deu a chupeta e o deitou em seu colo, deixando o rosto bem encostado ao seu peito esquerdo, chacoalhava o bebê, tentando acalma-lo. Aos poucos o choro cessou e ele se aquietou, ficando aconchegado à mãe. Tive a impressão de que o fato de a mãe ter demorado tanto para atender Romário fez com que ele a percebesse como seio mau, demandando um tempo maior para que ele a aceitasse como seio bom. 
No par G3, os bebês praticamente não choravam quando o cogêmeo estava sendo cuidado, sendo muito mais freqüentes as cenas onde a mãe atendia a um bebê enquanto o co-gêmeo aguardava.

3 semanas: Encontrei a mãe no quarto dos bebês. Luiz estava no berço, acordado. Kátia estava mamando no peito direito.

7 semanas: Logo Kátia se movimentou e resmungou. Luiz estava de olhos abertos e a mãe lhe disse que precisava cuidar da irmãzinha. O bebê ficou quieto e a mãe o colocou no berço, agasalhando/cobrindo com cobertor e acolchoado. Deu a chupeta, que o bebê sugou e logo adormeceu.

Esse fato merece ser destacado, pois neste par o clima familiar era mais tranqüilo do que nos demais. Ficava uma impressão de que a mãe parecia mais bem preparada para atender aos gêmeos, talvez pelo fato de ter feito psicoterapia durante a fase de gestação.

Nos quatro pares de gêmeos de mesmo sexo (G1, G2, G4 e G5), a mãe apresentava sinais de irritação quando os dois bebês a requisitavam ao mesmo tempo, ou seja: reclamava, falava alto, dizia não saber o que fazer! Por outro lado a mãe de G3 (sexos diferentes) se mantinha tranqüila, conversava com os gêmeos em tom de voz baixo e dificilmente demonstrava irritação.

A amamentação no peito foi realizada sempre de forma individual em todos os pares. Sendo que, desde o início, havia a complementação com 
mamadeiras. 


\subsection{Atendimento conjunto mãe-gêmeos}

O atendimento mãe-gêmeos foi considerado conjunto quando a mãe dividia sua atenção e cuidados com os dois bebês ao mesmo tempo.

Destacaram-se três fenômenos:

A mãe cuida de um bebê (carrega, alimenta ou faz a higiene) e atende à solicitação do co-gêmeo colocado em extensor de colo.

A mãe coloca os dois bebês em extensores de colo, interage com ambos ao mesmo tempo: dando alimento, conversando, brincando.

A mãe interage com um dos bebês através de conversas, gestos ou carinhos e repete os mesmos comportamentos com o co-gêmeo.

Nos pares G1, G2 e G3, desde as primeiras semanas de vida, aconteceram cenas onde a mãe cuidava de um dos bebês enquanto conversava com o co-gêmeo que estava em algum extensor de colo.

G1, 7 semanas: Enquanto Inês mamava a mãe olhava para a Carol e Ihe falava, dizendo que a irmãzinha estava mamando e não ficava quietinha como ela estava. Percebi que algumas vezes a mãe conversava com Inês ou Carol, sendo que ambas parecem prestar atenção à voz da mãe. Mesmo quando a mãe estava com Inês no peito e Carol deitada na cama, a uma distância de mais ou menos um metro, a mãe lhe falava e ela ficava atenta com os olhos fixos na mãe, o mesmo acontecia com Inês, quando estava no colo. 
G2, 6 semanas: Enquanto amamentava Ana Maria, Ana Flávia começou a resmungar. A mãe conversou com ela, virou o bebê de lado (voltada para a mãe) e ficava batendo de leve no corpo do bebê como se a ninasse, com a mão direita; enquanto isso mantinha Ana Maria no peito, apoiada no braço esquerdo. Aos poucos, Ana Flávia ficou quieta, chegando a sorrir com os olhos fechados.

G3, 19 semanas: A mãe disse que precisava dar frutas para Kátia, saiu da sala e logo retornou trazendo mamão e banana amassados. Carregou a bebê, sentando-a no colo, colocou uma fralda sob o queixo e lhe deu colheradas da papa. A princípio a bebê fez careta e cuspia o alimento, a mãe insistiu dizendo que precisava comer a frutinha, pois Ihe faria bem, principalmente porque ela tinha 0 intestino preso e também porque o co-gêmeo havia gostado bastante. Aos poucos, a bebê foi comendo praticamente toda a porção que a mãe havia preparado. Enquanto isso, Luiz olhava para a mãe, sorria e vocalizava. A mãe retribuía a comunicação de Luiz sorrindo e falando com ele. Houve algumas vezes em que Luiz regurgitou.

Nos pares G4 e G5, o fenômeno foi mais freqüente a partir da $27^{\mathrm{a}}$. semana.

G4, 29 semanas: A mãe veio e conversou com Fernando, perguntando porque chorava tanto. Assim que o carregou, o bebê cessou o choro. A mãe o levou ao quarto onde Gustavo estava pelado deitado na cama de casal, sobre a toalha de banho. A mãe tentou deitar Fernando na cama, mas ele resmungou, então a 
mãe sentou na cama, com Fernando sentado em seu colo. A mãe conversava com ambos os gêmeos mostrando um bebê para 0 outro. A mãe continuou a cuidar de Gustavo passou pomada no genital e nádegas de Gustavo e o vestiu, colocando a camiseta igual à de Fernando, a calça de mesma cor, variando levemente o tom de azul e meias diferentes.

G5, 36 semanas: A mãe se aproximou dos bebês com a mamadeira e carregou Romário, oferecendo o leite a ele. Mário imediatamente começou a choramingar, então a mãe puxou o carrinho dele mais para perto dela e lhe deu a chupeta. A mãe falava com ele carinhosamente, explicando que a mamadeira dele havia ficado na creche e ele teria que esperar um pouco para mamar. Romário cuspia o leite e a mãe insistia para que ele mamasse, até que desistiu e o colocou no carrinho novamente. A mãe conversou com o bebê que reclamou ao ser retirado do colo, mas logo ele se acalmou.

A alimentação através de mamadeira na maioria dos pares (G2, G3, G4 e G5) geralmente ocorria de forma individualizada, com o bebê no colo da mãe. Houve raras ocasiões em que a mãe colocava os dois co-gêmeos em extensores de colo e segurava as mamadeiras de ambos. Muitas vezes, quando estava presente um cuidador auxiliar, a mãe se ocupava de um bebê e a mãe, do outro.

Por volta da $14^{\mathrm{a}}$. semana, aumentou a ocorrência de situações nas quais os bebês eram colocados em extensores de colo e a mãe interagia com ambos praticamente ao mesmo tempo. Essas cenas sugerem que os gêmeos vivenciavam poucas situações duais (mãe-bebê), pois na maioria das vezes a 
relação ocorria com a participação de três pessoas: mãe / gêmeo / co-gêmeo. Através das vinhetas abaixo colocadas, é possível ter uma idéia do que se passava nas várias famílias. Dificilmente cada gêmeo conseguia ter exclusividade da atenção materna a não ser nas situações onde havia o revezamento de sono e vigília.

G1, 23 semanas: Desta vez, a mãe ficou ao lado do berço durante todo o tempo em que estiveram tomando leite. Percebi que Inês logo colocou a mão na mamadeira, enquanto Carol chegou a pegar na mão da mãe, como se quisesse manter a proximidade com a "mãopeito". Entretanto, a mãe logo retirou a mão e apoiava apenas a mamadeira, sendo que por algum tempo Carol cuspia parte do leite enquanto sugava. Em algum momento, a mãe arrumou a mamadeira de Carol e logo disse Ah, é a outra!!! Então foi arrumar a mamadeira de Inês, que estava sugando ar. Tive a impressão de que a mãe estava mais preocupada, em cuidar para que os bebês não ingerissem ar, do que nas observações anteriores.

G2, 14 semanas: No restante do tempo, a mãe deu chupeta para ambos os bebês. Percebi que agora as duas usam os mesmos modelos e cores. Cada uma chupou a chupeta enquanto a mãe balançava as cadeirinhas, cantarolando para fazer os bebês dormirem.

G3, 23 semanas: A mãe percebeu suas "reclamações" e veio atender. Conversou com os bebês falando com Luiz que ele já tinha feito arte e não dava sossego para a irmã. Embora as palavras da mãe fossem de repreensão, o tom de voz era delicado e sorria muito, 
parecendo demonstrar estar contente com as peripécias do Luiz.

G4, 28 semanas: Fernando resmungou e a mãe colocou a mamadeira em sua boca novamente, desta vez o bebê aceitou. A mãe ficou deitada na cama, tendo a cabeça de Fernando sobre o braço esquerdo e com a mão esquerda apoiava a mamadeira. Com a mão direita, passando sobre Fernando, ela segurava a mão de Gustavo e conversava com ele. Foi uma cena bonita e interessante, pois a mãe alimentava um e conversava com o outro gêmeo.

Ao longo destas cenas, eu ficava a pensar que a atenção da mãe está sempre dividida, pois ela não fica só com um bebê, mesmo que esteja alimentando um bebê, que está em seu colo, não consegue ficar só com ele, sua mente está dividida!

G5, 23 semanas: Pouco depois, a mãe colocou Mário no carrinho e desta vez ele ficou quieto, acompanhando os movimentos da mãe, que havia se voltado para Romário, conversando com o bebê que estava deitado no carrinho. A mãe pegou uma fralda e chupeta no carrinho de Romário e deu para Mário. A mãe conversava com Romário e o bebê respondia com sorrisos. Nestes momentos Mário ficava também olhando para a mãe. Pouco depois a mãe pediu à irmã que buscasse no quarto a chupeta e o "cheirinho" (fralda de tecido) de Mário, pois ele estava usando as de Romário; assim que a garota trouxe, a mãe fez a troca de objetos e colocou chupeta e "cheirinho" para cada um dos bebês. 
O par G1 permanecia a maior parte do tempo em extensores de colo desde as primeiras semanas de vida, sendo que muitas vezes a mãe permanecia próxima e interagindo com os bebês. Porém, uma situação chamou a atenção - a alimentação através de mamadeira - que era ministrada da seguinte forma: cada bebê era colocado deitado num extensor de colo, com o frasco apoiado em travesseiros, permanecendo então sozinho enquanto sugava. A mãe deixava os bebês num dos cômodos da casa e se ausentava, permanecendo em outro local. Muitas vezes, o frasco se deslocava da posição adequada e o bico saia da boca, logo o líquido não chegava até a boca e o bebê ficava sugando ar. Noutros momentos, o frasco caía e o bebê chorava. Por vezes, o bebê chorava bastante até que a mãe viesse atender. Essas cenas foram muito freqüentes nos primeiros meses de vida, gerando em mim - observadora - sentimentos de angústia por me sentir identificada com os gêmeos aparentemente em situação de desamparo.

Por volta de 40 semanas, algo aconteceu e mudou a situação: a mãe havia deixado os bebês no quarto, tomando leite com as mamadeiras apoiadas em travesseiros, então Carol pegou a mamadeira e agitou, sujando os berços com leite. A partir de então, a mãe passou a ficar com os bebês e geralmente segurava as mamadeiras de ambas, enquanto se alimentavam.

G1, 40 semanas: A mãe estava sentada no sofá com Carol no colo e Inês deitada no sofá. A mãe estava dando mamadeiras de leite para os bebês, com a mão direita segurava a mamadeira de Inês e com a esquerda mantinha Carol no colo, com a cabeça deitada nesse braço da mãe, que também segurava a mamadeira.

As mães muitas vezes repetiam o mesmo comportamento ao 
atender aos dois co-gêmeos, fenômeno presente desde as primeiras semanas nos pares G1 e G3 e mais freqüentes a partir da $25^{a}$. semana nos pares G4 e G5. Ficava a impressão de que a mãe buscava manter a "igualdade" no atendimento a ambos os filhos. 


\subsection{Disputa do colo/atenção materna}

O par G1 manifestou de forma mais efusiva a disputa pelo colo materno, principalmente no período de 31 a 47 semanas. O co-gêmeo G1-b foi amamentado no peito por um período mais longo, parecendo haver certa preferência da mãe por esse bebê. Por outro lado, muitas vezes a mãe se ausentava do local onde os bebês estavam colocados, os extensores de colo. É possível que esses fatos mobilizassem os bebês no sentido de buscar mais a atenção materna, que era pequena e ao mesmo tempo coletiva.

Neste mesmo par, G1, houve uma cena onde G1-b (Inês) foi amamentada no peito e G1-a (Carol) na mamadeira, tendo vomitado em seguida. As falas da mãe e avó materna presentes na cena chamaram a minha atenção.

G1, 3 semanas: A avó questionou a mãe se não iria dar o peito à Carol, a qual respondeu que Inês havia mamado nos dois peitos. A avó falou à Inês você tomou todo o leite da sua irmã e agora? A mãe então retirou a mamadeira de Carol. Colocou-a numa posição mais vertical, praticamente sentada no colo da mãe, imediatamente o bebê deu uma golfada, e o leite saiu num jato sobre a cama e parte de seu macacão. A mãe parece ter se assustado. Limpou o bebê, a avó comentou que havia sujado o pé e parte da perna da "roupa" de Carol que ia ficar cheirando azedo, logo comentou que já era quase a hora de outro banho. A mãe fez vários comentários com a avó, quase que pensando alto, questionando se o leite teria sido bem preparado (pela própria mãe), se era hora de o bebê mamar, se estaria com fome naquele momento, se o leite do peito teria sido 
melhor do que a mamadeira, ao mesmo tempo em que dizia que a Inês havia mamado tudo, enquanto a Carol dormia.

Senti que a mãe estava angustiada com a situação, enquanto Carol parecia dormir tranqüilamente após ter expulsado aquele leite "mau". Fiquei com a sensação de que o bebê teria se recusado a receber o "leite mau" por desejar sim o “leite bom" do peito da mãe.

O par G3 chegava a puxar partes do corpo da mãe, buscando atenção:

46 semanas: A mãe sentou no colchão perto dos bebês, falava com eles e mostrava brinquedos para ambos. Num certo momento, a mãe começou a brincar com Luiz e fazer carinho nele. A mãe ficou quase deitada no colchão estando de frente para Luiz e de costas para Katiuscia, que engatinhou, apoiou nas costas da mãe e ficou de pé. A mãe riu e falou com a filha você está aí, vem brincar com o Luiz, vem! Kátia riu bastante.

$\mathrm{Na}$ maioria dos pares, a disputa pela atenção materna se manifestava através de resmungos com semblante choroso ou então de gritinhos acompanhados de sorriso. 


\subsection{Atendimento pai-gêmeos}

Houve poucas situações onde os pais estiveram presentes nas situações de observação, conforme explicado anteriormente.

Apenas no par G5 foi possível observar situações de atendimento individual pai-gêmeo, onde um bebê era atendido enquanto o outro aguardava. Este pai ficou desempregado durante alguns meses, então permanecia na residência por mais tempo e, ocasionalmente, auxiliava a mãe nos cuidados com os bebês.

G5, 36 semanas: Poucos minutos depois, Romário começou a choramingar e a mãe pediu que o pai the desse a mamadeira. A mesma que Romário havia usado, e que havia sido preparada novamente com leite. O pai incentivava Romário a segurar o frasco sozinho, a mãe comentava que na creche as atendentes deviam estar segurando a mamadeira para o bebê, pois, segundo a mãe, ele antes sabia mamar sozinho, e agora não queria mais fazer isso. $\mathrm{O}$ pai continuou falando para o Romário segurar e colocava as mãos do bebê em volta do frasco, Romário segurava apenas com uma das mãos e assim a mamadeira saía da boca. Então a mãe falou para o pai deixar que ele ficasse com a mamadeira assim mesmo, que depois ele bebia, como fez num outro dia. O pai fez o que a mãe sugeriu, permanecendo perto de Romário por alguns minutos, entretanto o conteúdo da mamadeira ia caindo fora e o pai recolheu a mamadeira. Enquanto isso Mário olhava em direção ao pai que estava de costas para ele.

Os pais de G1 e G2 estiveram presentes em algumas observações, 
entretanto cada pai ficava distante dos gêmeos quase o tempo todo, permanecendo em locais diferentes da casa.

Nos pares G3, G4 e G5, foi possível perceber que o pai geralmente repetia o mesmo comportamento com os dois co-gêmeos, dando a impressão de tentar manter a "igualdade" de atendimento.

G3, 32 semanas: Logo ouvi um barulho de passos, imaginei ser o pai, fato logo confirmado pela mãe, que falava com os bebês que o papai havia chegado. O pai foi ao quarto e falava alto com os bebês. Tanto Luiz quanto Kátia pareciam ficar mais excitados ao ver o pai. Agitavam o corpo e sorriam olhando para ele. O pai carregou Luiz, levantando-o para o alto e balançando o bebê sobre sua cabeça. Luiz ria bastante. Em seguida colocou Luiz no berço e fez o mesmo com Kátia, que também reagiu sorrindo. Enquanto isso Luiz soltou as mãos da grade e caiu dentro do berço, batendo a cabeça na madeira a ponto de fazer um som alto. A mãe o socorreu imediatamente, entretanto o bebê sequer resmungou. A mãe disse que ele parecia já estar ficando acostumado de tanto bater a cabeça.

G4, 6 semanas: Pouco depois o pai foi ao berço beijou Fernando e Gustavo, fez algum comentário a respeito do sossego/vida boa dos bebês e despediu-se, saindo do quarto. Os bebês praticamente não se incomodaram com o toque do pai.

G5, 38 semanas: O pai se aproximou de Mário, que imediatamente olhou em direção ao pai e sorriu, de uma forma intensa. Parecia estar radiante por avistar o pai. O pai fez carinho com as mãos e 
beijou o bebê. O pai chama de oi nego... Romário olhava em direção ao pai e co-gêmeo atentamente. Em seguida, o pai se aproximou do Romário e repetiu praticamente os mesmos gestos. Romário reagiu com sorrisos. Enquanto o pai brincava com Romário, Mário ficava atento, olhando e agitando o braço, batendo a mãozinha no seu próprio corpo, repetindo um gesto que já havia apresentado em outras situações, quando parece estar tentando chamar a atenção de alguém.

Embora a presença paterna fosse pequena durante as observações, houve disputa pelo colo em três pares (G1, G4, G5), sendo mais expressiva em G5. Assim, é possível imaginar que a interação pai-gêmeos deveria ocorrer de forma significativa em horários não observados.

44 semanas: Romário resmungou e o pai se aproximou dele chamando-o por um apelido. A simples fala do pai fazia com que ele parasse de reclamar. Quando o pai falava com Romário, Mário logo olhava para o pai e sorria, agitava os braços e apertava as bexigas usando a mão e o toco de braço. A minha impressão era de que: se um dos bebês recebia atenção do pai, o outro logo reivindicava a atenção para si também, dando a impressão de que o triângulo estava acontecendo. Quando isso ocorria, o pai logo se voltava para Mário e conversava com ele também. 


\subsection{Relacionamento intra-par de gêmeos}

Houve grande diferença na idade em que o relacionamento entre os co-gêmeos começou a ser observado nos cinco pares. Entretanto, fazendo uma leitura mais cautelosa dos dados, pude perceber que o par G1 ficava a maior parte do tempo em extensores de colo e muitas vezes os gêmeos eram colocados lado a lado. Até mesmo os berços ficavam encostados através das grades laterais, logo favorecendo os contatos entre os co-gêmeos.

Os fenômenos observados na relação intra-par de gêmeos foram:

Um dos gêmeos agride (bate/ puxa partes do corpo/ morde) o cogêmeo.

Disputas de brinquedos, um dos co-gêmeos tenta e/ou pega o objeto que o outro está manipulando.

Toques físicos gêmeo/co-gêmeo não agressivos.

Disputa de alimento.

Desde as primeiras semanas, foi possível perceber que os gêmeos reagiam à presença do co-gêmeo, mudando o comportamento e pareciam até ficar mais tranqüilos quando colocados próximos entre si.

G1 16 semanas: A mãe retornou logo, ajeitou o travesseiro de Carol, colocou uma fralda e mais outro travesseiro e colocou a chuca de chá em sua boca. Carol parou de chorar imediatamente; sugava o bico com força e logo fechou os olhos. Fiquei com a impressão de que reagiu a esse objeto como se fosse um peito. A mãe a cobriu 
com um cobertor e Carol ficou com o corpo encostado na grade/protetor do berço, com a cabeça voltada para a esquerda. Foi interessante perceber a reação de Inês quando a co-gêmea parou de chorar. Inês parou de chorar momentaneamente e olhou em minha direção com expressão interrogativa, como se perguntasse o que aconteceu? Logo voltou a chorar.

O fenômeno foi percebido com mais freqüência a partir da $25^{\mathrm{a}}$. semana nos pares G2 e G5.

G2, 43 semanas: Ana Flávia sentou atrás da rede, ou seja, seu rosto ficava atrás da rede e Ana Maria sentou em sua frente, de tal maneira que as redes separavam os rostos dos bebês. Segue-se uma cena linda, onde as crianças brincavam de esconde-esconde, ficando com o rosto atrás da rede por alguns segundos e a seguir reapareciam para a co-gêmea. Davam gargalhadas como eu nunca vira.

G5, 49 semanas: Romário se aproximou do berço que tem uma cômoda e prateleira acoplada. Ali havia muitos calçados empilhados. Romário sentou e começou a pegar os calçados, manuseava por alguns segundos e jogava ao chão. Em seguida pegava outro calçado e assim por diante. Mário sentou perto de Romário e também realizava os mesmos movimentos. Parecia que era uma equipe brincando com os calçados.

Nos pares G3 e G4 este fenômeno foi percebido a partir da $7^{\mathrm{a}}$. semana. 
G3, 11 semanas: Por vezes Luiz olhava em direção à mão de Kátia que se movimentava ao seu lado, chegando a ficar "vesgo".

G4, 8 semanas: Num certo momento em que Gustavo chorou mais forte, Fernando movimentou a cabeça em direção ao co-gêmeo dando a impressão de procurava o som do choro. Fernando estava movimentando braços e pernas, vagarosamente. Coincidência ou não, estendeu o braço em direção a Gustavo e acabou encostando a mão no rosto do co-gêmeo, que acabou lambendo a mão do cogêmeo.

Tais fatos parecem refletir a importância da relação intra-par de gêmeos como uma intensa e precoce relação dual, a qual pode ser significativa na tentativa de compreendermos as relações triádicas que se estabelecem entre a mãe e os co-gêmeos.

Comportamentos agressivos entre os co-gêmeos já foram percebidos a partir da 28a. semana nos gêmeos G3:

A mãe saiu da sala por alguns momentos, em um deles Luiz se aproximou da co-gêmea de tal forma que ela estava na posição supina e ele na prona, Luiz segurou e puxou a orelha de Kátia que chorou forte. A mãe estava fora da sala. Imaginei que a bebê pudesse ser machucada e afastei o Luiz. Kátia continuou a chorar, assim a mãe veio atendê-la.

A disputa por brinquedos, na maioria dos pares (G1, G2, G3 e G4) ocorreu a partir da $21^{\mathrm{a}}$. semana. No par G5, as disputas por brinquedo aconteceram 
mais tarde, entretanto esse par geralmente era colocado em carrinhos de bebê separados por certa distância, sem possibilidade de aproximação entre os gêmeos. Após a $30^{\mathrm{a}}$. semana de vida, a disputa por brinquedos foi maior, principalmente nos pares G1 e G4.

G1, 24 semanas: Carol e Inês estavam deitadas no chão da sala. Sobre um "tapete" coberto por acolchoado e cobertor. Pareciam estar muito bem ali, Carol estava de bruço e Inês na posição supina. À medida se deslocava, Carol pegava os brinquedos (quatro bichinhos de borracha, duas bexigas redondas e duas finas e compridas - um metro aproximadamente, dois bichinhos de pano e dois travesseiros) que encontrava "pelo caminho". Carol alcançava os objetos com facilidade, desde que estivessem próximos à sua mão, então colocava na boca. Em alguns momentos, Carol pegou uma extremidade da bexiga, enquanto Inês estava segurando na outra extremidade, assim, quando Inês "afrouxava os dedos", Carol puxava e "tomava o objeto", então Inês olhava em direção à bexiga que se afastava, parecendo não entender o que se passava. Em outros momentos, a situação acontecia de forma invertida e então Inês pegava a bexiga que estava com Carol.

G2, 47 semanas: Ana Flávia começou a pegar no travesseiro, como se tentasse tomar de Ana Maria. Havia outras almofadas (do sofá) que a babá colocou no chão, mas os bebês pegavam o travesseiro. Pareciam se alternar, deitando no travesseiro, sentando, mexendo nas outras almofadas. Até que ambas deitaram no travesseiro. 
se aproximou dele, então pôs a mão sobre a barriga do co-gêmeo mexendo em sua roupa e tentando pegar o tubo de pomada que estava na mão dele. A mãe a afastou.

G4, 50 semanas: Havia uma bola plástica grande e Fernando começou a manipulá-la com as duas mãos. Quase imediatamente, Gustavo também colocou as duas mãos na bola. Cada um puxava para um lado diferente, até que Gustavo tomou a bola para si. Fernando olhou para a mãe, que lhe falou hi, ele pegou a bola, toma dele toma... Pouco depois a mãe ajudou e Fernando recuperou a bola, logo depois a cena se repetiu e Gustavo pegou novamente, logo Fernando a recuperou outra vez. Embora houvesse disputa, parecia mais uma brincadeira e os bebês riam olhando um para o outro.

G5, 39 semanas: O pai estava deitado num colchão e no outro colchão estavam Mário e Romário sentados lado a lado. Romário estava manipulando um brinquedo em formato de argola que parecia ser um "mordedor", Mário olhava atentamente para o brinquedo e mãos de Romário, então aproximava a mão direita e pegava o brinquedo, seguia-se uma espécie de luta entre os gêmeos onde Romário segurava o mordedor com as duas mãos enquanto Mário segurava com a sua única mão e apoiava o toco do braço esquerdo no corpo de Romário e o empurrava até que o co-gêmeo largava o brinquedo. Passados alguns segundos era a vez de Romário tomar o objeto de Mário. Havia uma nítida luta pela posse do brinquedo entre os bebês, a "perda da posse" parecia ser motivadora para 
novas investidas e tentativas de reaver a posse perdida. $O$ comportamento dos bebês era muito semelhante quando perdiam a posse do objeto.

Outro fenômeno analisado foi a ocorrência de toques físicos não agressivos, que ocorreram desde a $2^{\mathrm{a}}$, semana em G1. Isso leva a pensar que, se colocados próximos entre si, os gêmeos olham e tocam seus respectivos cogêmeos em idade muito precoce, possibilitando talvez que a relação de objeto possa ser percebida de forma mais explícita.

G1, 4 semanas: Logo Inês começou a se movimentar de tal maneira que tocava a irmã várias vezes na cabeça, ombro, orelha, etc., por vezes era Carol que movimentava o braço direito (Inês estava deste lado) e tocava a face de Inês com os dedos ou dorso da mão; neste momento Inês tentava lamber a mão da irmã. Após poucos minutos Carol abriu os olhos e começou a chorar bem forte.

Nos demais pares, o fenômeno foi observado mais tarde: G2 e G4 14ª semana; G3 - 20ª semana; G5 - 32a . semana.

Os toques no corpo do co-gêmeo aparentavam mais uma forma de buscar conhecer o objeto, da mesma forma que os bebês, de forma geral, exploravam o seu próprio corpo.

G4, 18 semanas: Em alguns instantes os gêmeos ficavam praticamente paralisados, encostados um ao outro. Se o braço de Gustavo ficava próximo ao de Fernando, ele tentava abocanhar, chegando a roçar os lábios na mão ou antebraço do co-gêmeo. 
Nesses momentos, o semblante de Gustavo parecia não se modificar.

Em outras situações, os toques eram tão intensos que a mãe precisava intervir, evitando que os co-gêmeos se machucassem.

G4, 36 semanas: Ao finalizar o banho a mãe recolocou Gustavo sobre a cama para colocar roupas e fralda. Fernando se aproximou e ficava colocando as mãos em Gustavo, chegou a puxar o cabelo de Gustavo, sendo repreendido pela mãe. Fiquei com a impressão de que sua atitude era mais exploratória do que agressiva. Entretanto, era nítida a intenção de tocar o corpo do co-gêmeo. 


\subsection{Peculiaridades do atendimento mãe-gêmeos}

Além dos aspectos considerados anteriormente, alguns fatos chamaram a minha atenção, os quais merecem ser mencionados para posterior análise.

As gêmeas G1 (bivitelinos, sexo feminino) eram vestidas com roupas idênticas diariamente. Seus nomes eram bem diferentes, entretanto receberam o mesmo apelido, os dois bebês eram chamados de "Tatá". De tal forma que, por vezes, a mãe conversava com as crianças através de um fala esquisita, tipo: Tata a devolve o brinquedo da Tata! Fico a questionar quais seriam as conseqüências desta atitude materna na formação da identidade das crianças.

As gêmeas G2 (univitelinos, sexo feminino) eram extremamente parecidas, eram sempre confundidas pelas pessoas que delas cuidavam e muitas vezes a própria mãe olhava para a mancha (hemangioma) que uma delas tinha na cabeça para certificar a identidade dos bebês.

Os gêmeos G4 (univitelinos masculinos) eram também muito parecidos e até o final do primeiro ano de vida não eram chamados pelos próprios nomes, por toda a família. A mãe os chamava de bebezinho, bebê da mamãe, esse e aquele, esse aqui e esse aí... Chegando ao cúmulo de, numa situação em que um dos bebês adoeceu, o pai não saber qual estava hospitalizado.

34 semanas: Liguei para avisar a família que não faria observação em função de viagem. Na residência, não atendiam e então falei com o pai, através do celular. O pai me informou que estava no hospital, onde um dos gêmeos estava hospitalizado. Me mostrei sensibilizada 
e perguntei qual dos bebês estava doente, ao que o pai respondeu aí você me apertou... um está na casa da minha sogra e o outro está aqui comigo... agora não vou saber quem é!!!!

Neste momento, fiquei a pensar nas conseqüências desta maneira de "identificar" e se relacionar com os gêmeos; nem o pai sabe quem é quem!!!!!!

Nos pares G1, G2 e G4, parecia haver uma preocupação maior em preservar as semelhanças entre os bebês, enquanto nos demais este aspecto era menos freqüente. Entretanto, nos cinco pares, foi possível perceber que a mãe e o pai procuravam manter uma atitude parecida ao cuidar dos gêmeos, ou seja, oferecendo os mesmos tipos de alimentos e fazendo brincadeiras praticamente iguais para os co-gêmeos.

Por outro lado, no par G1, parecia haver uma preferência da mãe pela filha Inês que nasceu com um quilo a menos que a co-gêmea. Friso o aspecto peso, porque nos primeiros meses de vida muitas vezes esse bebê era chamado de Bebezinho e a co-gêmea de Bolota! Além disso, depois de alguns meses apenas Inês era amamentada ao peito.

Nos cinco pares observados, houve várias situações em que os gêmeos eram colocados em extensores de colo. Além dos próprios berços e carrinhos de bebê, eram comuns: rede, acolchoado e colchão de casal colocado entre os sofás da sala de estar, cadeirinhas e andadores.

O colchão de casal colocado na sala foi tão freqüente que eu já nem ficava surpresa ao adentrar a casa e me deparar com a cena. Parecia fazer parte do pacote da família de gemelar. 
A princípio, o uso tão grande de extensores de colo me levou a pensar que os gêmeos vivenciam contato físico com a mãe e demais cuidadores numa proporção menor, aliás, bem menor que os bebês singulares. Entretanto, principalmente nas situações em que a mãe fica sozinha para cuidar dos dois bebês, o uso dos extensores é bastante apropriado. Até mesmo os andadores, que sempre considerei desnecessários e até prejudiciais aos bebês, se bem usados, acabam funcionando como boas estratégias para a mãe cuidar dos dois co-gêmeos simultaneamente. Isto porque muitas vezes os bebês requisitam o colo e/ou querem se deslocar quando a mãe está alimentando ou fazendo a higiene do co-gêmeo, assim estando no andador a criança se desloca e segue a mãe, sendo que se estivesse no chão, tentando andar, poderia cair e se machucar, por exemplo.

Os aspectos supramencionados permitem fazer um paralelo com a literatura e serão comentados a seguir. 


\section{DISCUSSÃO}

Alguns anos atrás, uma gêmea adulta confidenciou-me que muitas vezes Ihe perguntavam: como se sente por ser gêmea? E ela respondia: e você, como se sente por não ser gêmeo? Sua resposta parece até grosseira, mas dá idéia da condição especial em nascer de forma singular ou gemelar.

Ao analisar os relatórios das observações dos cinco pares de gêmeos, pude perceber algumas sutilezas nas relações: mãe-gêmeos, pai-gêmeos e intra-par de gêmeos. Zazzo (1986) considerava o homem-gêmeo diferente do homem-singular, chegando a sugerir que o gêmeo poderia ser considerado um desvio, visto pela ótica do singular. Chamo a atenção para o desvio principalmente ao verificar alguns aspectos percebidos nos dados coletados, especialmente com os gêmeos idênticos (G2 e G4) frequentemente confundidos pelos seus cuidadores, inclusive pela mãe. Mesmo nos gêmeos fraternos, o desvio parecia evidente quando a mãe apelidou as co-gêmeas G1 da mesma forma: embora fossem fisicamente tão diferentes ambas eram chamadas de Tata.

A idéia do duplo mencionada por Freud (1919b), que leva tanto ao encantamento quanto à estranheza, mobiliza nos pais sentimentos contraditórios, levando-os a tratar os gêmeos como se fossem iguais, principalmente quando repetem as mesmas ações ao interagir com os co-gêmeos. Assim, fica a impressão de que não buscam conhecer as diferenças entre os filhos.

O fato de serem tão confundidos pelos cuidadores ao longo do primeiro ano de vida (G2 e G4), bem como o fato de os pais usarem de estratégias para tentar deixar os gêmeos fraternos mais parecidos entre si, através dos nomes 
semelhantes (G5), apelidos iguais (G1), utilização de roupas idênticas (G1), podem contribuir para a confusão vivenciada pelos gêmeos pesquisados por Zazzo (1986, p. 250), os quais apresentavam dificuldades em usar a primeira pessoa do singular (eu) referindo-se a si mesmos no plural (nós) até por volta dos cinco anos de idade.

As maneiras como os pais lidavam com os filhos gêmeos levam à idéia de que tentavam igualar os gêmeos e tratá-los como partes do mesmo ser.

Nos pares de gêmeos univitelinos (G2 e G4), foram comuns as situações onde encontrei dificuldade em reconhecer quem era quem. Era necessário que houvesse alguma situação onde a mãe ou outro cuidador falasse o nome dos bebês ou eu mesma percebesse algum sinal (hemangioma na cabeça de uma das gêmeas-G2 e cicatriz em um dos gêmeos-G4) para que eu pudesse identificá-los adequadamente. A minha confusão era grande, causava certa angústia e aflição, por não saber nomear cada bebê. A princípio pensava ser um problema para a coleta de dados da pesquisa, mais tarde pensei ser um aspecto importante a ser observado/pensado, pois dava idéia do quanto os pais e demais cuidadores deveriam ter dificuldade em reconhecer cada co-gêmeo, além de ponderar sobre as conseqüências disso para o desenvolvimento da identidade em cada gêmeo.

Numa de suas pesquisas, Zazzo (1986) encontrou alguns pais (20 em 500) que usavam artifícios (pulseiras, brincos) que facilitavam a identificação dos co-gêmeos, entretanto, nos participantes do estudo aqui relatado, isso não foi observado. Pelo contrário, as meninas (G1 e G2) usavam brincos idênticos!

Zazzo mencionou o fato de os próprios gêmeos muitas vezes se nomearem com o mesmo apelido, dando a impressão de se perceberem como iguais até os cinco anos de idade. A coleta de dados, no nosso caso, abrangeu 
apenas o primeiro ano de vida, não sendo possível perceber esse aspecto, pois a fala ainda não estava desenvolvida.

Entretanto, outro fato chamou a atenção: a maneira como o bebê explorava e lou buscava contato com o corpo do co-gêmeo. Por volta de três a quatro meses de idade, quando colocados lado a lado, foi possível observar o bebê olhando e tentando pegar/abocanhar a mão do co-gêmeo, da mesma maneira que agia em relação a partes do seu próprio corpo, dando a impressão de perceber os dois corpos como partes de si mesmo!

Encontramos na literatura outros autores, tais como Machado (1980) e Gibson (2002), que enfatizavam a necessidade de a mãe se relacionar com os gêmeos de forma individual e não em bloco. Entretanto, nos cinco pares observados, geralmente eram nomeados no plural: os gêmeos, os bebês, as crianças, etc. Apenas no par G3 (sexos diferentes) se percebia uma diferenciação mais efetiva e o bloco era considerado de forma mais suave.

fato de serem tratados como se fossem 2 em 1 deve contribuir para as situações de competição e disputa pela atenção materna, tão freqüente nos cinco pares observados.

Por outro lado, convém chamar a atenção para o fato de, muitas vezes, os próprios co-gêmeos usarem de estratégias para favorecer o atendimento individualizado. Digo isso porque ficava muito evidente o comportamento de cada bebê em aguardar pelo cuidado do co-gêmeo, mas, se após fazer a higiene e/ou alimentar o co-gêmeo, a mãe continuasse carregando/conversando ou fazendo algum carinho, imediatamente o bebê reclamava.

Ficava a impressão de que o bebê percebia a presença do co- 
gêmeo, de certa forma compreendia a sua necessidade de ser atendido/cuidado e conseguia aguardar alguns minutos para então receber a atenção materna. Entretanto, se após os momentos de holding a mãe mantivesse sua atenção e afagos (carinhos, conversas) dirigidos ao primeiro bebê atendido, o co-gêmeo parecia se sentir o excluído e reivindicava a atenção materna para si.

Outro fenômeno muito freqüente em todos os pares foi o revezamento sono/vigília. Quando observei o par G1, considerei simplesmente interessante e mera coincidência encontrar um co-gêmeo dormindo e o outro acordado. Sendo comuns situações onde um bebê adormecia e imediatamente o outro acordava! Ao continuar a coleta com os demais pares, percebi ser algo muito freqüente em todos eles, a ponto de a mãe de G2 comentar que, nas reuniões de família, as pessoas diziam que ela parecia estar sempre com um bebê no colo, já que ambos revezavam entre si os estados de sono e vigília.

O revezamento sono/vigília parece funcionar como estratégia para assegurar o atendimento mãe-bebê de forma individualizada. É difícil imaginar como bebês tão jovens poderiam se organizar de forma tão sofisticada, mas ... 0 fenômeno ocorreu em todos os pares!

O revezamento sono/vigília proporcionava a cada co-gêmeo uma situação de vivência dual com a mãe. A impressão que eu tive é que, após ser cuidado pela mãe, cada bebê adormecia e assim permitia que o co-gêmeo também recebesse atenção e cuidados! Não consigo entender como o processo acontecia, de que maneira os co-gêmeos em idade tão precoce "combinavam" esta estratégia, entretanto o fenômeno se repetiu em todos os pares principalmente na faixa de seis a vinte e cinco semanas.

Tais fatos me levaram a concordar com os autores que consideram 
os gêmeos como: unidade existencial complexa (MIGLIO, 1995), gang em miniatura (BURLINGHAN, 1952), sociedade intragemelar (GEDDA, 1951) e também o paradoxo dos gêmeos (ZAZZO, 1984, apud MIGLIO, 1995) que ressalta ao mesmo tempo a semelhança física e a diferença psicológica entre os gêmeos.

O funcionamento dos gêmeos como uma equipe parece ter os seus primórdios ao longo do primeiro ano de vida, uma vez que foram comuns as situações em que os bebês disputavam brinquedos e pegavam os mesmos objetos de decoração da casa. De tal forma que, muitas vezes, a mãe acabava de tirar um bebê de determinada situação onde corria perigo e/ou tentava alcançar um objeto proibido, seguido imediatamente pelo co-gêmeo que repetia os mesmos gestos ou travessuras. Embora não tenha sido possível relatar com detalhes certas sutilezas do comportamento dos co-gêmeos, eram comuns as situações nas quais ambos pareciam se comunicar através de olhares e então iniciar uma travessura qualquer. Um exemplo disso:

G3, 48 semanas: Passados poucos minutos, os bebês se entreolharam e engatinharam em direção ao sofá. A mãe falou vai começar a sessão sofá. Os dois bebês engatinharam rapidamente e subiram no sofá, sentando em seguida. Olharam um para o outro e riram, chegando a dar gargalhadas. Logo depois, ficaram de pé apoiados no encosto do sofá. A mãe riu e falou com eles a respeito de terem conseguido subir lá. Comentou comigo que faziam isso sempre e se deslocavam sobre o sofá, de tal maneira que ela temia que eles se machucassem. Logo a seguir, Kátia se jogou do sofá, indo de cabeça sobre o colchão, como se mergulhasse numa piscina; Luiz fez o mesmo, caindo praticamente em cima da co-gêmea. Os dois bebês praticamente rolaram um sobre o outro, dando 
gargalhadas. Toda a cena foi acompanhada pela mãe que ficava atenta e ria o tempo todo, falando para os bebês cuidarem para não se machucar. A cena do sofá se repetiu algumas vezes, sendo que na maioria das vezes os bebês subiam praticamente juntos no sofá. Kátia descia "de cabeça" enquanto Luiz deitava bem na beirada do sofá e rolava caindo sobre o colchão. Sempre que conseguiam subir no sofá, bem como "cair" no colchão, os bebês se entreolhavam e davam gargalhadas.

Neste par foi a primeira vez que presenciei uma brincadeira conjunta, onde os bebês pareciam planejar a ação que executariam, por meio de trocas de olhares, sorrisos e verdadeiras gargalhadas. Após a cena se repetir umas cinco vezes, os dois bebês ficaram no colchão, quietos, a ponto de a mãe falar com eles dizendo/perguntando se estavam cansados de tanto pular/brincar.

Na cena observada, a mãe estava conivente com a ação dos bebês, entretanto observei várias outras cenas, inclusive com os demais pares, em que os bebês faziam verdadeiras "artes", mexendo em coisas ou indo a lugares proibidos. Muitas vezes, a mãe chamava por eles, os quais olhavam para ela, entreolhavam-se e se deslocavam engatinhando mais rapidamente até atingir o alvo proibido. Assim, "a equipe" parecia estar funcionando desde muito cedo, ficando a impressão de que, muitas vezes, a relação intra-par era mais intensa do que a relação mãe-bebê naquele instante. A idéia parece referendar a fala de Miglio (1995, p. 59), mencionada anteriormente, que considera o vínculo gêmeo-gêmeo tão primário quanto o vínculo mãe/co-gêmeo.

Acredito que, se os co-gêmeos desenvolvem uma relação tão intensa durante o primeiro ano de vida, é possível que as relações entre cada bebê 
co-gêmeo e a mãe, bem como entre cada um e o pai envolvem questões que vão além das relações objetais vivenciadas pelos bebês singulares. Aliás, a cada dia que passa estou mais convencida de que a relação intra-par de gêmeos é tão intensa que pode ser que o co-gêmeo seja, de fato, o primeiro objeto de amor de cada bebê gêmeo. Entretanto poderia ser um amor narcísico, considerando o cogêmeo como um espelho ou extensão de si mesmo, lembrando aqui a idéia do duplo mencionado por Zazzo (1986).

Autores mencionados anteriormente neste trabalho, tais como Fabozzi (1995) e Athanassiou (1986), relataram o atendimento psicoterápico a gêmeas adultas que se sentiam fusionadas ao co-gêmeo e à co-gêmea. No caso relatado por Fabozzi, a paciente falava com a mãe através do co-gêmeo, não assumindo a própria identidade; e, no caso relatado por Athanassiou, a gêmea apresentou problemas emocionais sérios quando a co-gêmea se casou. Em ambas as situações havia um vínculo simbiótico intra-par de gêmeos que persistiu até a vida adulta, dando indícios das dificuldades encontrados pelo trio em desenvolver relações objetais sadias.

Athanassiou (1986) mencionou a possibilidade da triangulação edípica ocorrer entre os co-gêmeos e sua mãe, hipótese também mencionada por Joseph (1975), o qual mencionou a necessidade de se realizarem pesquisas sobre os aspectos pré-edipianos em gêmeos.

Foi possível perceber que a vivência de situações triádicas foi praticamente constante em todos os pares, ou seja, a não ser nas situações onde havia o revezamento sono/vigília, a mãe estava sempre cuidando dos dois bebês simultaneamente. Certamente a forma como cada trio mãe-gêmeos funcionava tinha características próprias, entretanto o fenômeno mais freqüente em todos 
implicava em a mãe se ocupar de um bebê e, ao mesmo tempo, manter sua atenção no co-gêmeo.

Em cada par de gêmeos, acabei por perceber os cuidados maternos acontecendo de forma "especial", tal qual descreverei a seguir.

Em G1, a mãe muitas vezes se distanciava dos bebês em algumas situações, colocava os gêmeos em extensores de colo, deixando as mamadeiras apoiadas em travesseiros e se ausentando daquele cômodo. Isso provocava em mim uma identificação com cada bebê e eu sentia uma sensação de abandono extremamente grande. Muitas vezes essa dupla ficou chorando por vários minutos sem que a mãe viesse atendê-las, sendo que houve uma observação em que a mãe justificou sua atitude em função da orientação do pediatra que sugeriu que as deixasse chorar para "acostumar" a não ficar no colo... Quando a mãe se aproximava para atender a um dos bebês, era muito freqüente a disputa pelo olhar e atenção materna, os bebês choravam muito!

Outro fato que chamava a minha atenção neste par era a preferência que a mãe demonstrava ter pelo bebê (Inês) que nasceu menor, o qual era tratado de forma mais carinhosa e foi amamentado por mais tempo. Quando os bebês já eram capazes de se deslocar engatinhando, aconteceram cenas de agressividade onde Carol puxava os cabelos e mordia Inês. Essas cenas demonstram o quanto a triangulação era intensa e como os co-gêmeos sentiam ciúmes quando a mãe se dedicava aos cuidados do co-gêmeo.

No par G2, inicialmente a mãe procurava atender as crianças de forma bastante semelhante. Muitas vezes, carregava os dois bebês ao mesmo tempo e as embalava de uma forma que me parecia extremamente difícil e incômoda - cada bebê era colocado na posição prona nos ante-braços da mãe. A 
fisionomia dos bebês era muito semelhante, a mãe as confundia e em diversas vezes usava a mancha de hemangioma que havia na cabeça de uma delas para conferir a identidade dos co-gêmeos.

Aos poucos, essa mãe foi modificando a relação com os bebês, chegando por vezes a não atender o bebê que chorava, como forma de castigá-lo pela noite mal dormida... Entretanto, houve pelo menos uma cena em que puniu o bebê errado! Isso me levou a pensar nas dificuldades vivenciadas pelos gêmeos, pois, além de ter menos tempo de vivência de situações duais, ainda precisam lidar com a mãe mais cansada e pouco disponível para as crianças.

Quando o par G2 estava com aproximadamente três anos, visitei a família e percebi que a irmã mais velha tinha ainda muita dificuldade em identificar as gêmeas, fato este que me levou a pensar que a confusão na identificação das crianças persistia. Após aquela data, não mais encontrei a família, ficando sem condição de saber as conseqüências do fenômeno.

O par G3 possuía a mãe mais tranqüila! Desde os primeiros dias a mãe se relacionava com os bebês de forma mais individualizada, ressaltando em suas falas comigo as características específicas que percebia em cada co-gêmeo. Embora muitas vezes cuidasse dos dois bebês ao mesmo tempo, enquanto se ocupava de um bebê conversava com o co-gêmeo que parecia se sentir contido pela voz da mãe e logo se tranqüilizava. Dificilmente esses bebês choravam por muito tempo! A sensação vivenciada por mim era que a mãe estava mais bem preparada para acolher dois bebês do que as demais mães. Por outro lado, acredito que o fato de os bebês serem de sexo diferente fazia com que a mãe evitasse coloca-los na mesma situação de "igualdade" que as mães de bebês de mesmo sexo faziam. 
A atitude da mãe do par G3 parecia estar de acordo com as idéias de Szejer (1999) de que o falar com os bebês os auxilia a melhor compreender o mundo ao seu redor.

O par G4 era muito parecido fisicamente, a ponto de o pai não saber a quem estava acompanhando no hospital, em situação mencionada anteriormente. Talvez para esconder a dificuldade de identificar os bebês, a mãe não os chamava pelos respectivos nomes e sim com os mesmos apelidos: meu bebê, bebezinho da mamãe, esse e aquele. Fato que me levou a pensar que essa mãe colocava os dois bebês no mesmo lócus afetivo, provavelmente favorecendo uma confusão de identidades entre eles futuramente. Foi possível perceber que a mãe se relacionava com os co-gêmeos de forma muito semelhante, como se fosse sempre a mesma criança! Outro fato que chamava a atenção era que, embora fosse muito meiga e carinhosa com os bebês, ao cuidar de um deles praticamente abandonava o co-gêmeo, que muitas vezes passava alguns minutos chorando sem que fosse atendido. A mãe olhava em direção ao bebê, mas se ocupava dele apenas quando terminava de atender ao co-gêmeo. Assim deixava o primeiro bebê já alimentado ou higienizado em extensor de colo, então cuidava do co-gêmeo de forma tão carinhosa quanto havia agido com o primeiro. Muitas vezes se desculpava com este bebê, dizendo que estava cuidando do irmãozinho...

Os pais do par G4 procuraram ajuda psicoterápica para as crianças há poucos meses, quando os gêmeos estavam com quatro anos de idade. O motivo alegado foi a dificuldade em relação ao desenvolvimento da própria identidade, ou seja, ambos se intitulam os gêmeos e quando alguém perguntava o nome a cada um deles, um era capaz de se auto nomear enquanto o outro falava o nome de ambos como se possuísse um nome duplo - Gustavo Fernando. Além disso, ambos 
chamavam o co-gêmeo de irmão e na escola estavam apresentando problemas de relacionamento com os colegas. Até o início da psicoterapia, o pai ainda não conseguia identificar os co-gêmeos e a mãe os identificava pelo nome, entretanto, na maioria do tempo, referia-se aos filhos como esse e aquele.

Assim, pude perceber que a maneira como os pais dos gêmeos univitelinos os identificava, ou seja, sem reconhecer quem era quem, persistia por alguns anos e, pelo menos no par G4, contribuiu para a manifestação de sintomas de confusão de identidade em pelo menos um dos co-gêmeos.

O par G5 apresentava características físicas bem diferentes e a mãe então os diferenciava desde o início. Neste par, o que mais chamava a atenção era as palavras agressivas que a mãe usava ao falar com os bebês, embora usasse tom de voz e gestos carinhosos. Percebia os co-gêmeos de forma diferente, mas o tratamento dedicado a ambos era bastante semelhante, logo dando a sensação de também tratá-los como partes de um mesmo ser...

Ao analisar os dados coletados, percebe-se o quanto Lewin (1994) tem razão ao afirmar que o gêmeo nunca está sozinho com sua mãe, pois mesmo estando um dos co-gêmeos ausente (até pela morte), estaria presente na mente dela. A mesma autora enfatizou que, ao ser amamentado ao seio, o bebê se sente vitorioso e, ao mesmo tempo, temeroso pelos possíveis ataques invejosos do cogêmeo. Considerando que muitas vezes o bebê precisa aguardar para ser atendido pela mãe, enquanto ela se ocupa do co-gêmeo, é bastante pertinente a idéia acima exposta, mesmo porque durante as observações percebi muitas vezes que o bebê que aguardava ficava furioso: chorava, olhava para a mãe com aspecto raivoso e, quando já conseguia se deslocar engatinhando, chegava a alcançá-los e agredir a mãe ou o co-gêmeo. 
Neste ponto, acho importante lembrar da hipótese por mim levantada anteriormente de que o gêmeo enfrenta um conflito extra que contribui para a formação de sua identidade: além das relações objetais com mãe e pai, precisa se haver com a relação gemelar. Alguém poderia me dizer que todas as pessoas que possuem irmãos passam por situações semelhantes, entretanto é preciso lembrar que, entre os bebês singulares, há uma diferença de idade de pelo menos nove meses, enquanto os gêmeos tem a mesma idade e, portanto, o mesmo nível de imaturidade emocional para lidar com conflitos psíquicos tão intensos.

Por outro lado, através das observações realizadas, foi possível verificar que, se colocados próximos entre si, desde as primeiras semanas de vida, os gêmeos trocam olhares e contatos físicos, como pudemos perceber em G1. Este fato parece referendar as idéias de Biale (1989) de que o vínculo criança-criança em gêmeos é tão significativo que poderia até minimizar a atenção materna reduzida que os gêmeos recebem.

Segundo a mesma autora, os gêmeos prematuros requisitam a atenção materna quando o co-gêmeo estaria sendo atendido desde os quatro meses de idade, entretanto percebemos aqui que, por volta de seis semanas, os bebês aguardavam enquanto o co-gêmeo era atendido e em outros momentos reclamavam através de resmungos ou choro. O fenômeno ficava mais evidente quando o primeiro bebê atendido já havia sido colocado em algum extensor de colo, estava sereno e começava a chorar quando a mãe voltava sua atenção e cuidados ao co-gêmeo. Logo, o fenômeno foi detectado em idade mais precoce.

Novamente acredito que os gêmeos se mostram capazes de suportar o holding do co-gêmeo, mas se sentem deixados de lado quando a mãe demonstra carinho apenas para o co-gêmeo. De tal forma, o triângulo se instala e o 
terceiro excluído reclama, assim o fenômeno edípico parece ser mais precoce e intenso nos gêmeos, com ênfase nas relações fraternas.

Biale (1989) fez referência a comportamentos agressivos intra-par de gêmeos ocorrendo por volta de oito meses, entretanto no par G1 já foram percebidos na $23^{a}$. semana, logo, por volta do sexto mês de idade. É possível que, neste caso, o ambiente tenha contribuído para tanto, considerando a forma como Carol e Inês eram cuidadas pela mãe nos primeiros meses de vida, ou seja, a mãe dava mais carinho para Inês em detrimento de Carol.

Lewin (1989) ressaltou a questão dos gêmeos sentirem a duplicidade e unicidade de cada um, ou seja, funcionam como seres únicos e ao mesmo tempo integrantes de um par. Neste sentido, a autora falava do conflito vivenciado pelos gêmeos em desenvolver a própria identidade e ainda se sentirem unidos ao co-gêmeo. No par G1, em que onde eram comuns as manifestações agressivas intra-par, houve uma situação interessante a esse respeito, quando Carol havia se machucado e Inês parecia ter assumido as dores dela!

G1, 54 semanas Ao chegar, hoje, encontrei a mãe com Carol no colo, o bebê estava chorando intensamente, enquanto Inês estava deitada num colchonete, no chão, tomando Yacult na chuca. (...) A mãe se sentou com Carol no sofá e logo Inês subiu no sofá também. Estava na casa uma moça, que permaneceu na sala o tempo todo.

Cada vez que Carol chorava, Inês olhava para todas as pessoas presentes e apontava com a mão em direção à Carol, como se quisesse contar o que estava percebendo. Num certo momento, Inês começou a "conversar" com a moça, emitia vários sons, apontava em 
direção à Carol, etc. A moça respondia e Inês continuava "falando".

Enquanto isso, Inês se aproximava da mãe, tanto quando estava com Carol no colo, como se estivesse sentada ou de pé fazendo qualquer movimento. A mãe dava atenção conversando e/ou carregando-a. Inês parecia atenta a todos os movimentos que se faziam na sala. Houve algum momento em que o telefone tocou, imediatamente Inês disse "ô" como se falasse alô... a avó deu a ela um telefone de brinquedo, que tem várias teclas que produzem sons diversos; a princípio a avó a incentivava a tocar as teclas e logo o próprio bebê tomava a iniciativa, assim que o aparelho emitia o som, Inês falava "ô" e também outros sons, como se conversasse ao telefone.

A minha impressão era de que Inês estava aflita e pedindo à mãe que buscasse algum socorro para a co-gêmea. As cenas seguintes parecem confirmar a minha hipótese, quando a mãe telefona em busca de auxílio!

Após algum tempo, o irmão entrou na sala, questionando porque Carol chorava tanto. A mãe perguntou se havia acontecido alguma coisa com Carol, enquanto ela estava com ele lá fora, no balanço; o garoto disse que toda hora que alguém tirava o bebê do balanço o braço dela "estalava"... a mãe olhou para a observadora como se pedisse socorro, falou com o filho que não podia fazer assim pois o bebê poderia se machucar, etc. A avó interferiu dizendo que o braço do bebê era igual ao de "frango", portanto muito frágil... assim parecia tentar explicar ao neto a gravidade da situação... 
A mãe foi ao telefone e ligou para o consultório do médico, perguntando se ele já havia chegado e contando o que acontecia com o bebê. A seguir telefonou para o pai das crianças, contou o que se passava e pediu que ele viesse para levar o bebê ao médico.

Na semana seguinte, soube que Carol havia "deslocado o braço" e por isso sofria tanto!

Em tal situação fiquei com a nítida sensação de que Inês se sentira identificada com Carol e por isso reagiu daquela maneira até que a co-gêmea fosse cuidada, levando-me a refletir sobre a possibilidade de haver uma forte identificação introjetiva entre os co-gêmeos, podendo inclusive se pensar na intensidade do vínculo gemelar ser até maior do que o vínculo com a mãe.

Além disso, ficou em mim a impressão de que Inês reagiu à situação de forma mais madura do que poderia se esperar de uma criança tão jovem. Acredito que o fato de os gêmeos precisarem aguardar para serem atendidos, passando, pois, por mais situações de frustração do que os bebês singulares, levá-los-ia a desenvolver o aparelho para pensar em idade mais precoce, favorecendo também a capacidade de auto-continência de forma mais intensa do que nos singulares.

Sobre a evolução da sexualidade em crianças, Freud (1905) afirmou que o primeiro período de masturbação ocorre no período de lactância. Inicialmente haveria a auto-estimulação e, mais tarde, seria possível que a criança fosse estimulada sexualmente por outras crianças. No caso dos gêmeos observados, aconteceram cenas onde os bebês tocavam partes do corpo do cogêmeo, numa atitude provavelmente exploratória, mas que poderia também estar 
servindo como estimulação prazerosa.

Outro aspecto mencionado por Freud, no mesmo texto, é a questão da visualização de partes do corpo de outras crianças como fonte de estimulação e prazer. O fato de os gêmeos geralmente estarem juntos e participando das cenas onde o co-gêmeo é higienizado favorecia a visão e até mesmo o toque nos genitais do co-gêmeo em idade muito precoce. Em alguns pares, houve situações em que a mãe precisou intervir para que esses contatos fossem coibidos.

Ao abordar as questões edípicas, Freud e Klein mencionaram a importância das relações fraternas, sendo que nas situações triangulares muitas vezes os desejos tanto sexuais quanto agressivos podem se voltar para um dos irmãos em vez dos genitores. Freud (1900b) enfatizou que, muitas vezes, as situações vivenciadas com os irmãos eram associadas a sonhos com conteúdo edípico relacionado às figuras parentais.

Os contatos físicos entre os pares de gêmeos eram bastante freqüentes, principalmente quando ambos eram colocados em extensores de colo, tais como colchão colocado no chão. Nos primeiros meses, os contatos envolviam toques manuais nas mãos, pés e partes do rosto: orelha, nariz e boca. Quando tocado pelo co-gêmeo na boca, eram comuns cenas onde o bebê sugava a mão do co-gêmeo. Tais situações me levavam a pensar em várias possibilidades: o prazer do toque no co-gêmeo versus o prazer de ter parte do seu corpo sugado, prazer em ser tocado e em sugar parte do corpo do outro. De qualquer maneira, sensações que poderiam desencadear sensações ligadas à sexualidade. Mais tarde, quando já se deslocavam engatinhando, eram comuns situações onde passavam por cima do co-gêmeo para alcançar um local ou objeto que estivesse à sua frente. Assim, podendo perceber contatos incestuosos precoces nos bebês gêmeos, cujas 
barreiras contra o incesto ainda não haviam sido erigidas.

Nos cinco pares de gêmeos, a presença paterna era pequena. Os bebês permaneciam com as respectivas mães na maior parte do tempo, em função da atividade profissional dos pais. Embora esta seja a situação comumente encontrada na vida da maioria dos bebês, é preciso considerar que nos singulares a mãe acaba por se ocupar de um bebê apenas e, mesmo que existam outros irmãos, que são sempre mais velhos, a mãe consegue vivenciar situações de relação dual com o bebê. Nos pares observados, as cenas envolviam sempre as relações triangulares, a não ser nos momentos de revezamento sono/vigília.

Assim, o que se verifica é que nos gêmeos a entrada do terceiro elemento aparece na relação mais cedo do que nos singulares, em função da onipresença do co-gêmeo. Os resultados encontrados neste trabalho demonstraram que os bebês reagiam à presença do irmão muito cedo, logo manifestando a vivência da triangulação precocemente.

Um dos aspectos analisados foram as agressões dirigidas ao cogêmeo e à mãe, as quais foram mais freqüentes nos pares G1 e G3. Embora durante as observações as agressões não ocorressem com freqüência, muitas vezes as mães dos cinco pares observados comentavam o fato de os bebês estarem se comportando de forma agressiva. Em tais situações as mães falavam para não bater, não puxar o cabelo, não empurrar, não passar por cima do cogêmeo. Tudo isso dava sinais de que, quando o triângulo se instalava, os gêmeos manifestavam ciúmes recíprocos e até inveja da situação vivenciada entre a mãe e o co-gêmeo, culmindo com a agressão física.

Tais fatos me levaram a lembrar das idéias de Freud, no texto Totem e Tabu (1913), no qual dizia que, na ausência do pai, poderiam eclodir 
sentimentos de competição e até desejos fratricidas. Se os gêmeos passam tanto tempo vivendo relações triangulares com a mãe e o co-gêmeo, se o gêmeo não é capaz de fazer o corte na relação dual entre mãe e gêmeo tal qual o pai interfere no vínculo mãe-bebê e assim "liberta" o filho da simbiose com a mãe, então é possível que o vínculo triangular mãe-gêmeos seja de caráter mais simbiótico e patogênico do que ocorre nos singulares.

$\mathrm{Na}$ literatura estudada, encontrei Athanassiou (1991), a qual considera que os gêmeos poderiam se sentir envolvidos pela mesma pele psíquica a qual poderia, ou não,estar ligada à pele psíquica da mãe. A autora afirmou ainda que a tentativa de romper essa pele levaria a sentimentos dilacerantes. Outro aspecto analisado foram os sentimentos de interpenetração vivenciados pelos cogêmeos (motivados pela identificação introjetiva exacerbada intra-par de gêmeos), e que nem sempre a mãe de gêmeos possui suficiente capacidade de revêrie para acolher as angústias dos gêmeos. Assim, a mãe contribuiria para agravar as rivalidades entre os gêmeos ao invés de minimizá-las.

Fiquei a pensar nas dificuldades encontradas pelas mães em atender aos dois co-gêmeos simultaneamente, principalmente nos gêmeos de mesmo sexo. Por vezes, o choro do bebê que não estava sendo cuidado era tão intenso que me levava a ficar extremamente angustiada.Quer dizer, quando os bebês estavam em extensores de colo e a mãe conversava com ambos ao mesmo tempo o clima era sempre de alegria e descontração. Ou seja, quando a mãe não fazia a separação do par, a paz reinava! Por outro lado, quando os gêmeos alternavam os estados de sono/vigília, conseguiam manter o atendimento individualizado e também ficavam aparentemente bem. A impressão é que se o controle da situação estivesse a cargo do par de gêmeos, a separação era 
consentida e aceita, caso contrário o desconforto, a reclamação e até a ira contra a mãe e/ou co-gêmeo era visível.

No par G3 (sexos diferentes), as manifestações supracitadas eram bem mais amenas. Fico a pensar se seria pelo fato de a mãe conseguir ser mais preparada para lidar com essas questões ou se o fato de serem de sexos diferentes os levava a estabelecer vínculos na relação gêmeo/co-gêmeo, mãe/gêmea e mãe/gêmeo, levando a sentimentos edípicos específicos a cada co-gêmeo, lembrando como Klein $(1932 b, 1932 c)$ descreveu de forma tão diferente o desenvolvimento da sexualidade nos bebês de sexo feminino e masculino.

Uma das questões levantadas inicialmente neste trabalho é se poderia haver a escolha objetal do co-gêmeo, substituindo a figura paterna no triângulo edípico, ou se haveria apenas um comportamento imitativo entre os cogêmeos visando receber a atenção materna.

Ao longo das observações, foi possível perceber diversas cenas onde havia uma visível disputa entre os co-gêmeos pelo olhar e atenção materna. Dava a impressão de que, se o olhar da mãe estivesse voltado para o co-gêmeo, o bebê se sentia como o terceiro excluído e reclamava a atenção sobre si. Dessa forma, não parecia haver um comportamento apenas imitativo, uma vez que os cogêmeos usavam de estratégias com nuances diferentes para buscar a atenção materna. O similar parecia ser a expectativa de receber o mesmo tratamento de que o co-gêmeo desfrutava. Isso ocorreu diversas vezes na relação entre cada mãe e seus gêmeos, como também nas poucas situações onde houve algum tipo de relacionamento pai-gêmeos. Quando falo em expectativa, baseio-me no fato de cada bebê estar reclamando pela atenção de um dos genitores por meio de resmungos, ou até alegres gritinhos, e tranqüilizar-se quando recebia o mesmo tipo 
de cuidados e/ou brincadeiras que o co-gêmeo havia recebido.

Logo, o que se evidenciava era o desejo de ser o eleito para usufruir das atenções parentais, havendo uma luta com o co-gêmeo para ser a figura em destaque na situação triangular.

Em várias sessões de observação, havia um certo paradoxo: ocorreram momentos em que um dos gêmeos aguardava enquanto a mãe cuidava do co-gêmeo e noutras situações a mãe atendia a um gêmeo e conversava com o co-gêmeo que estava em algum extensor de colo. Na segunda situação, o cogêmeo que não estava sendo atendido chamava a atenção da mãe através de olhares, sorrisos ou até expressões faciais de desagrado. O fato de a mãe olhar, sorrir e/ou conversar com o co-gêmeo parecia suficiente para que se tranqüilizasse e ficasse sereno.

Tais cenas propiciam várias reflexões, dentre elas o fato de o bebê: ser capaz de perceber o co-gêmeo como um outro que necessita de cuidados, bem como de o bebê não agüentar ser completamente excluído pela mãe enquanto ela se ocupa do co-gêmeo.

A segunda idéia acima sugerida corrobora a colocação de Athanassiou (1986) de que o relacionamento mãe-gêmeo está sempre sendo perturbado pela presença do co-gêmeo. Por outro lado, o fato de o gêmeo ser capaz de perceber o co-gêmeo como alguém que necessita ser cuidado naquele momento merece ser considerado de maneira especial, principalmente em cenas tais como:

Par G4, 12 dias: A mãe estava amamentando um dos bebês quando entrei no quarto. Enquanto isso, o co-gêmeo resmungou e a mãe 
disse que ele sabia que precisava esperar o primeiro acabar de mamar, então disse ao bebê que estava no peito que pudesse continuar mamando tranqüilo.

A cena ocorreu na primeira visita que fiz à mãe, que estava ainda hospitalizada junto com os bebês, os quais haviam nascido prematuros. Eu não fui informada sobre quem era quem, por isso não nomeei os bebês. Mas o que me chamou a atenção foi que com apenas doze dias de nascido a mãe falou com os bebês desta maneira e, por incrível que pareça, o bebê que estava no berço imediatamente parou de resmungar após a fala da mãe! É difícil avaliar se a voz ou as palavras dela funcionaram como continentes, mas o que se percebe é que o bebê excluído se tranqüilizou ao ouvir a mãe.

Tal situação me levou a pensar nos textos de Szejer (1999) que tanto enfatizou a importância das falas das mães e até da própria psicanalista para fazer com que os bebês, recém-nascidos inclusive, pudessem compreender o que se passava com eles.

Assim, fico a questionar se as colocações de Athanassiou a respeito da raiva que o co-gêmeo sente por não estar sendo amamentado seria sempre pertinente ou se os gêmeos teriam recursos mais sofisticados para se conter em tais momentos em idade tão precoce!

Evidentemente, as observações mencionadas no capítulo resultados dão notícia de situações onde a sensação de exclusão levou os gêmeos inclusive a atos agressivos dirigidos ao co-gêmeo e até à mãe. Cenas estas que corroboram a idéia de Athanassiou não só em relação à amamentação ao seio, quanto em outros momentos nos quais algum co-gêmeo se sente o excluído na 
situação triangular - mãe/gêmeos.

Uma outra maneira de abordar a relação entre os gêmeos e seus pais consiste em considerar o par de gêmeos como unidade, constituindo o terceiro vértice do triângulo edípico. Neste sentido, é possível pensar nas situações onde os gêmeos estavam tranqüilos, manipulando brinquedos, por exemplo, e se a mãe iniciava alguma conversa com alguém, ambos os bebês começavam a resmungar como se buscassem sua atenção. O mesmo acontecia caso a mãe conversasse ao telefone. Ficava a impressão de que os gêmeos se uniam para buscar a atenção materna, funcionando então como unidade e não como antagonistas/rivais.

Ao considerar a possibilidade de os gêmeos se unirem, formando assim o terceiro vértice do triângulo, isso parece estar de acordo com as idéias propostas por Klein (1997b/1932) de que os irmãos poderiam funcionar como aliados contra objetos apavorantes, bem como se utilizarem mutuamente para trocar contatos físicos e obter gratificações mútuas. Tudo isso sendo usado como forma de se aliviar das dores causadas pelas vivências com o seio mau.

Ao focalizar a atenção em outro vértice do triângulo - a mãe, é possível fazer novas conjecturas retomando um aspecto mencionado por mim no início deste trabalho, decorrentes da teoria infantil de que a mãe incorporaria um pênis novo a cada cópula, e que o pênis se transformaria em crianças (KLEIN, 1997b/1932). Se o pênis possui aspectos bons e maus, então os novos bebês poderiam também ser considerados bons ou maus...

Essas idéias parecem explicar algumas atitudes das mães em relação a cada co-gêmeo, quando estas consideram, por vezes, que um dos gêmeos é bom e o outro é mau. Nos pares observados, encontrei pelo menos duas situações onde o fenômeno aconteceu: G1, um dos bebês, era tratado de forma 
agressiva e apelidado de Bolona enquanto a co-gêmea era a Bebezinha; G3, quando estavam ainda na maternidade, o menino era considerado calmo, a menina era rotulada como agitada e chorona. Mais tarde, ao longo das observações, a mãe de G3 mudou a percepção em relação aos co-gêmeos.

Ao falar sobre o desenvolvimento da sexualidade no menino, Klein mencionou que, após perceber os pais combinados, a criança aos poucos passa a perceber de forma separada e poderia dirigir os impulsos libidinais para a mãe, enquanto o ódio e a ansiedade seriam voltados para o pai. Entretanto poderia haver um deslocamento do ódio para outros objetos. No estudo em questão, poderíamos pensar no deslocamento para o co-gêmeo. Poderia até acontecer de os "pais combinados" constituírem um vértice, e os co-gêmeos funcionarem como segundo e terceiro vértices.

Um dos fenômenos mais observados foi o fato de o bebê aguardar para ser atendido enquanto o co-gêmeo era cuidado pela mãe. Para que isso possa acontecer, o bebê necessita ter uma idéia de que o co-gêmeo existe, de que ele necessita de cuidados, de que não irá esgotar a fonte de alimentos e cuidados que a mãe representa.

Para tanto, é preciso considerar que os gêmeos aqui observados foram capazes de controlar a inveja e ciúmes do co-gêmeo em idade precoce para então serem capazes de aguardar. Por outro lado, nas situações onde o co-gêmeo era atacado com gestos agressivos, percebia-se a manifestação dos ciúmes do cogêmeo em relação à mãe. Não creio que houvesse apenas um deslocamento de sentimentos que antes eram dirigidos ao pai, mas sim que eram dirigidos de fato ao co-gêmeo, que funcionava como o terceiro vértice do triângulo e que, naquele momento, teria levado o bebê a se sentir como o excluído. 
Os gêmeos vivenciam relações triádicas desde o início da vida, uma vez que mesmo quando a mãe cuida aparentemente de apenas um bebê-gêmeo, mostra-se atenta aos chamados do co-gêmeo. Embora não fale com o co-gêmeo, os olhares, as expressões faciais e os movimentos corporais da mãe denunciam sua atenção e pré-ocupação com o co-gêmeo.

$\mathrm{Na}$ vivência das situações triangulares, pude perceber que os gêmeos suportam o holding do co-gêmeo, mas reclamam dos carinhos que a mãe direciona ao co-gêmeo, cada gêmeo sente-se o excluído e reage negativamente à situação. Os gêmeos, muitas vezes, revezam os estados de sono e vigília de tal maneira que cada um pode usufruir da mãe, estabelecendo uma relação dual sem a interferência constante do co-gêmeo, evitando assim a triangulação.

A relação intra-par de gêmeos é muito intensa e freqüente. Os cogêmeos parecem utilizar de formas de comunicação sutis e pouco perceptíveis pelas outras pessoas. Assim, mesmo durante o primeiro ano de vida, funcionam como equipe seja para buscar a atenção materna e/ou dos demais cuidadores, para brincar ou para realizar travessuras. Fica a impressão de que há inúmeras situações nas quais a mãe fica colocada no vértice excluído do triângulo e o par é constituído pelos co-gêmeos.

Tais fatos remetem aos estudos de Freud e Klein, mencionados anteriormente neste trabalho, a respeito de as relações fraternas substituírem parcialmente as relações triádicas entre o bebê e seus pais.

Os fenômenos aqui estudados sugerem ainda, a meu ver, que a triangulação edípica se estabelece primordialmente entre os co-gêmeos e a mãe.

Devido às dificuldades em carregar/embalar dois bebês ao mesmo 
tempo, a mãe muitas vezes utiliza diversos tipos de extensores de colo, que facilitam cuidar dos dois co-gêmeos simultaneamente, tais como: berços, carrinhos de bebê, acolchoados e colchões colocados no chão, andadores, cadeirinhas de bebê e redes.

Além disso, é possível conjecturar a existência de pelo menos quatro formas de relação triangular envolvendo os gêmeos e seus pais, além do triângulo edípico filho-mãe-pai:

1) pai, mãe e gêmeos (considerando a unicidade do par);

2) gêmeo, co-gêmeo e casal parental;

3)gêmeo, co-gêmeo e mãe;

4) gêmeo, co-gêmeo e pai. 


\section{CONSIDERAÇÕES FINAIS}

Tenho a impressão de chegar o momento de parar um pouco!

A questão da gemelaridade continua sendo um mistério para mim. Entretanto, após vivenciar e analisar as observações destas famílias, fiquei com a impressão de que, embora cada mãe tente se relacionar de forma dual com o par de gêmeos, os co-gêmeos percebem a relação triangular desde muito cedo e lutam pela possibilidade de vivenciar situações duais com a mãe.

Desde muito tempo, fico intrigada com a questão do Complexo de Édipo em gêmeos e após finalizar a jornada aqui descrita fica a certeza de que a relação intra-par de gêmeos é muito intensa e certamente diferente daquela vivida pelos irmãos singulares.

Entretanto, tendo trabalhado apenas com o desenvolvimento dos gêmeos ao longo do primeiro ano de vida, fica a sensação de um serviço inacabado, precisando percorrer o longo caminho das demais idades e estudar os desfechos aos quais a triangulação mãe-gêmeos e pais-gêmeos vai levar.

É possível questionar até que ponto a mãe de gêmeos seria suficientemente boa, permitindo, como sugeriu Winnicott (1982), que a totalidade e a unicidade de cada co-gêmeo obtivessem pleno reconhecimento. Conforme relatei nos pares aqui observados, nem sempre isso foi percebido.

As maneiras como as mães e os pais lidavam com os co-gêmeos, favorecendo a confusão de identidades, demonstra a necessidade de criar serviços de atendimento a pais de gêmeos a fim de melhor instrumentá-los para enfrentar a 
difícil tarefa de acolher e cuidar de dois bebês ao mesmo tempo.

Finalizando, tenho sido procurada, no consultório, com muita freqüência, por pais de gêmeos, desde o primeiro ano de vida, para auxiliá-los na intensa labuta de cuidar de dois ou mais filhos de mesma idade. Isso ratifica esta tese e nos dá estímulo para continuar as pesquisas sobre esse tema tão intrigante, que são os gêmeos. 


\section{REFERÊNCIAS}

ACÁCIO, G. L. et al.Laser na terapia da síndrome de transfusão feto-fetal. Acta Cirúrgica Brasileira, São Paulo, v.20, n.6, p.478-481, nov./dez. 2005.

AMARAL, E. et al. Assistência à gestação gemelar. Revista Ciências Médicas, v.2, n.12, p. 173-183, abr./jun. 2003.

ATHANASSIOU, C. A study of the vicissitudes of identification in twins. International Journal of Psycho-analysis, London, n.67, p.329-336, 1986.

BEIGUELMAN, B.; COLLETTO, G. M. D. D.; SEGRE, C. A. M. Twinning rate in a sample from Brazilian hospital with a high standard of reproductive care. São Paulo Medical Journal, São Paulo, v.119, n.6, p.216-219, nov. 2001.

BIALE, R. Counseling families of disabled twins. National Association of Social Workers, Washington, p.531-535,1989.

BICK, E. A experiência da pele em relações de objeto arcaicas. In: SPILLIUS, E. B. Melanie Klein Hoje: Desenvolvimentos da teoria e da técnica. Rio de Janeiro: Imago, 1991. v.1. 194-198

BION, W. R. Estudos Psicanalíticos Revisados. Rio de Janeiro: Imago, 1994.

CAMARGO, C. H. P.; MONTEIRO, L. C.; TONIOLO, M. Um estudo comparativo sobre o grau de comprometimento nos testes psicológicos de dois irmãos gêmeos univitelinos com esquizofrenia. Psic: Revista de Psicologia da Vetor Editora, São Paulo, v.3, n.1. p.110-123. 2002.

CAMANO, L.; FAVA, J. L.; SOUZA, E. Intervalo entre o nascimento de gêmeos: morbidade e mortalidade do segundo gemelar. Revista Brasileira de Ginecologia e Obstetrícia, Rio de Janeiro, v.243, n.7, p.423-427, ago. 2001.

COSTA, F. S.; FUNAYAMA, C. A. R.; NOVAES, D. A. Gravidez gemelar com morte fetal de um dos gêmeos: avaliação neurológica dos gemelares sobreviventes.

Revista Brasileira de Ginecologia e Obstetrícia, Rio de Janeiro, v.24, n.2, p.107112, mar. 2002.

CRESTI, L.; LAPI, I. O esboço da relação mãe/bebê e a instituição hospitalar: díade ou tríade? In: LACROIX, M. B. Os Laços do encantamento: a observação de bebês, segundo Esther Bick e suas aplicações. Porto Alegre: Artes Médicas, 1977. p.148-162.

CROW, T. J. Assimetria cerebral e lateralização da linguagem: déficits nucleares na esquizofrenia como indicadores da predisposição genética. Revista de Psiquiatria do Rio Grande do Sul, Porto Alegre, v.26, n.2, p.122-134, maio/ago. 2004.

DAVISON, S. Mother, other and self: Love and rivalry for twins in their first year of life. Internatioal Review of Psicho-analisys, London, n.19, p.359-374, 1992. 
FABBOZZI, P. Dalla fusione gemellare alla nascita dell'individuazione: il caso di Silvia. In: MIGLIO, C. D. II Sé gemellare. Roma: Edizione Borla, 1995. p.154-164.

FREUD, Sigmund. A interpretação dos sonhos. In:

Sigmund Freud. Rio de Janeiro: Imago, 1900a/1974. v.4, p.11-322.

FREUD, Sigmund. A interpretação dos sonhos. In: Obras completas de

Sigmund Freud. Rio de Janeiro: Imago, 1900b/1974. v.5, p.323-569.

FREUD, Sigmund. Três ensaios sobre a teoria da sexualidade. In: . Obras completas de Sigmund Freud. Rio de Janeiro: Imago, 1905/1974. v.7, p.118-230.

FREUD, Sigmund. Análise de uma fobia em um menino de cinco anos: sobre as teorias sexuais das crianças. In: Rio de Janeiro: Imago, 1909a/1974. v.10, p.11-154. Obras completas de Sigmund Freud.

FREUD, Sigmund. Cinco lições de psicanálise. In: Obras completas de Sigmund Freud. Rio de Janeiro: Imago, 1909c/1974. v.11, p.11-51.

FREUD, Sigmund. Um tipo especial de escolha de objeto feita pelos homens (Contribuições à Psicologia do Amor). In: Obras completas de Sigmund Freud. Rio de Janeiro: Imago, 1910/1974. v.11, p.147-157.

FREUD, Sigmund. Notas psicanalíticas sobre um relato autobiográfico de um caso de paranóia (Dementia Paranoides). In: Obras completas de Sigmund Freud. Rio de Janeiro: Imago, 1911/1974. v.12, p.15-108.

FREUD, Sigmund. Sobre a tendência universal à depreciação na esfera do amor (Contribuições à Psicologia do Amor II). In: Obras completas de Sigmund Freud. Rio de Janeiro: Imago, 1912/1974. v.11, p.159-173.

FREUD, Sigmund. Totem e tabu. In:

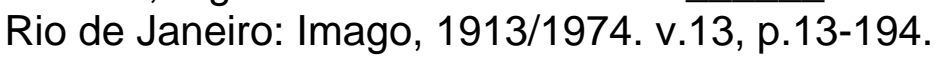

Obras completas de Sigmund Freud.

FREUD, Sigmund. Sobre o narcisismo: uma introdução. In: Obras completas de Sigmund Freud. Rio de Janeiro: Imago, 1914/1974. v.14, p.85-119.

FREUD, Sigmund. Conferência XIII: Aspectos arcaicos e infantilismo dos sonhos. In: . Obras completas de Sigmund Freud. Rio de Janeiro: Imago, 1916[1915]/1974. v.15, p.297-307.

FREUD, Sigmund. Conferência XXI: O desenvolvimento da libido e as organizações sexuais. In: 1917[1916]/1974. v.16, p.375-395.

FREUD, Sigmund. História de uma neurose infantil. In: Obras completas de Sigmund Freud. Rio de Janeiro: Imago, 1918[1914]/1974. v.17, p.13-153.

FREUD, Sigmund. Uma criança é espancada uma contribuição ao estudo da origem das perversões sexuais. In: Obras completas de Sigmund Freud. Rio de Janeiro: Imago, 1919a [1918]/1974. v.17, p.223-253. 
FREUD, Sigmund. O 'Estranho'. In: . Obras completas de Sigmund

Freud. Rio de Janeiro: Imago, 1919b/1974. v.17, p.273-318.

FREUD, Sigmund.O Ego e o Id. In:

Rio de Janeiro: Imago, 1923/1974. v.19, p.13-83.

FREUD, Sigmund. Um estudo autobiográfico. In: . Obras completas de

Sigmund Freud. Rio de Janeiro: Imago, 1925[1924]/1974. v.20, p.13-92.

FREUD, Sigmund. Sexualidade feminina. In: Obras completas de

Sigmund Freud. Rio de Janeiro: Imago, 1931/1974. v.21, p.257-279.

FREUD, Sigmund. Conferência XXXI: A dissecção da personalidade psíquica. In: . Obras completas de Sigmund Freud. Rio de Janeiro: Imago, 1933a[1932]/1974. v.22, p.75-102.

FREUD, Sigmund. Conferência XXXII: Feminilidade. In: Obras completas de Sigmund Freud. Rio de Janeiro: Imago, 1933c[1932]/1974. v.23, p.139-165.

GIBSON, E. Compared to what? A family's strugle with the meaning of poverty, cultural variation and racial diference. Infant Observation: the international journal of infant observation and its aplications, London, v.5, n.3, p.47-68, 2002-3.

GUZZO, R. S. L.; ITO, P. C. P. Temperamento: características e determinação genética. Psicologia: reflexão e crítica, Porto Alegre, v.15, n.2, p.425-436. 2002.

KEEN, Ernest. Técnicas de Pesquisa. In: Introdução à psicologia Fenomenológica. Rio de Janeiro: Interamericana, 1979.

KLEIN, Melanie. Estágios iniciais do conflito edipiano. In: Amor culpa e reparação e outros trabalhos. Rio de Janeiro: Imago, 1928/1996. v.1, p.215-227.

KLEIN, Melanie. Os efeitos das situações de ansiedade arcaicas sobre o desenvolvimento sexual da menina. In: Janeiro: Imago, 1932a/1997. v.2, p.213-257. . A psicanálise de crianças. Rio de

KLEIN, Melanie. Os efeitos das situações de ansiedade arcaicas sobre o desenvolvimento sexual do menino. In: Janeiro: Imago, 1932b/1997. v.2, p.258-295. A psicanálise de crianças. Rio de

KLEIN, Melanie. O complexo de Édipo à luz das ansiedades arcaicas. In: Amor culpa e reparação e outros trabalhos. Rio de Janeiro: Imago, 1945/1996. v.1, p.413-464.

KLEIN, Melanie. Notas sobre alguns mecanismos esquizóides. In: culpa e reparação e outros trabalhos. Rio de Janeiro: Imago, 1946/1996. v.1, p.17-43. 
KLEIN, Melanie. Sobre a observação do comportamento de bebês (1952). In: . Inveja e ingratidão e outros trabalhos. Rio de Janeiro: Imago,

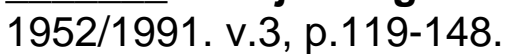

KLEIN, Melanie. Inveja e gratidão (1957). In: Inveja e ingratidão e outros trabalhos. Rio de Janeiro: Imago, 1957/1991. v.3, p.205-267.

KOMPINSKY, E. Observação de bebês: método e sentimentos do observador. In: CARON, N. A. (Org.). A relação pais-bebê: da observação à clínica. São Paulo: Casa do Psicólogo, 2000. p.9-43.

KÜBLER-ROSS, E. O túnel e a luz: reflexões essenciais sobre a vida e a morte. Campinas: Verus Editora, 2003.

JABBOUR, C.; MARQUES, L. Gêmeos: onde está a semelhança?. Rio de Janeiro: Papel Virtual, 2000.

JOSEPH, E. D. Psicanálise: ciência, pesquisa e estudo de gêmeos. Revista Brasileira de Psicanálise, São Paulo, v.9, n.1, p.83-115, 1975.

LEWIN, V. Working with a twin: implications for the transference. British Journal of Psychotherapy, London, v.10, n.4, p.499-510, 1994.

MARQUES, E. M.; RUDGE, M. V. C. Resultados perinatais de gêmeos com pesos discordantes ao nascer. Revista Brasileira de Ginecologia e Obstetrícia, Rio de Janeiro, v.24, n.6, p.389-394, jul. 2002.

MACHADO, D. V. M. Meus filhos gêmeos. São Paulo: ALMED, 1980.

MÉLEGA, M. P. A supervisão pelo método analítico. In: MÉLEGA, M. P. et al. Conduta humana estudo e investigação: observação psicanalítica e outros métodos. São Paulo: Centro de Estudos das Relações Mãe-Bebê-Família, [199-?]. v.4, p.17-43.

MÉLEGA, M. P. A supervisão da relação mãe-bebê: ensino e investigação. In: MÉLEGA, M. P. Observação da relação mãe-bebê método Esther Bick: tendências. São Paulo: Unimarco, 1997. p.119-138.

MIGLIO, C. D. II Sé gemellare. Roma: Edizione Borla, 1995.

PEREZ-SANCHEZ, M. Observações de bebês: relações emocionais no primeiro ano de vida. Rio de Janeiro: Paz e Terra, 1983.

PIONTELLI, A. De feto a criança: um estudo observacional e psicanalítico. Rio de Janeiro: Imago, 1995.

SALDANHA, P. H. Gêmeos: hereditariedade vs ambiência. São Paulo: HUCITEC/ EDUSP, 1980.

SZEJER, M.; STEWART, R. Nove meses na vida de uma mulher: Uma abordagem psicanalítica da gravidez e do nascimento. São Paulo: Casa do Psicólogo, 1997. 
SZEJER, M.; STEWART, R. A escuta psicanalítica de bebês em maternidade: Uma abordagem psicanalítica da gravidez e do nascimento. São Paulo: ABREP e Casa do Psicólogo, 1999.

VIOTTO, M. E. B. Conversando sobre gêmeos. Londrina: A autora, 1999.

WALLACE, M. Gêmeas silenciosas. São Paulo: Melhoramentos, 1988.

WINNICOTT, D. W. Gêmeos. In: A criança e seu mundo. Rio de Janeiro: Koogan, 1982. p.154-161.

WINNICOTT, D. W. O ambiente e os processos de maturação: estudos sobre a teoria do desenvolvimento emocional. Porto Alegre: Artes Médicas, 1983.

ZAZZO, R. Les Jumeaux: le couple et la persone. 2. ed. Paris: Presses Universitaires de France, 1986.

ZIMERMAN, D. E. Vocabulário contemporâneo de psicanálise. Porto Alegre: ARTMED, 2001. 